\title{
Chance Findings About Early Holocene Tidal Marshes of Grays Harbor, Washington, in Relation to Rapidly Rising Seas and Great Subduction Earthquakes
}

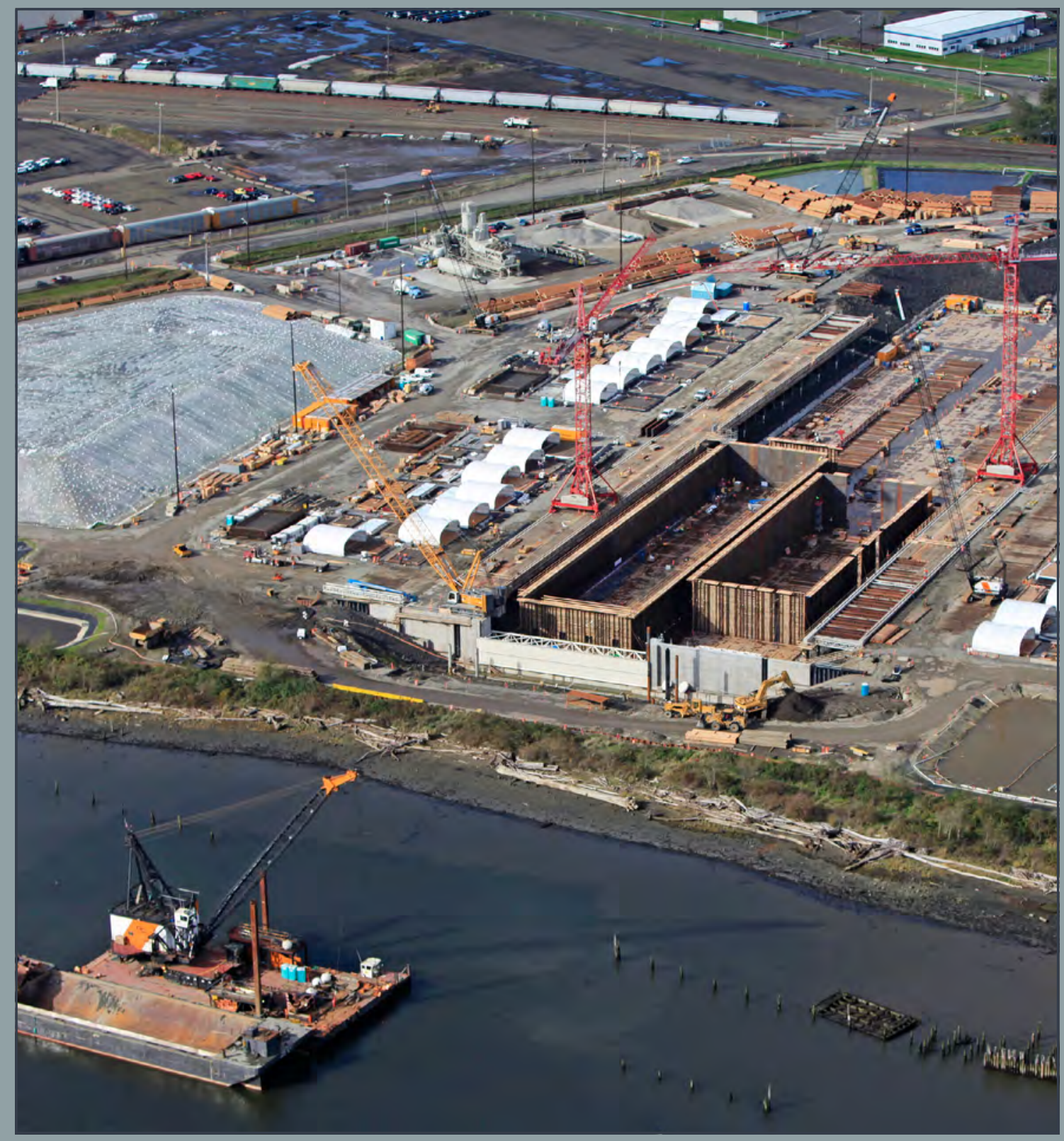

Scientific Investigations Report 2015-5063

Version 1.1, May 2016

U.S. Department of the Interior

U.S. Geological Survey 
COVER A dry dock under construction at Grays Harbor in 2011. Concrete pontoons cast in the completed facility now support a floating bridge along a state highway near Puget Sound. The dry-dock project opened a window into geologic history through a prerequisite search for archaeological remains. Borings for the archaeological search sampled tidal-marsh deposits thousands of years older than those previously observed beneath Pacific Northwest estuaries. This unexpected discovery provides an example of marshes that managed to build up apace with the sea when its level was rising about as rapidly as in forecasts for the current century. The ancient tidal-marsh deposits may also provide constraints on the history of great earthquakes along the Cascadia Subduction Zone. Photograph courtesy of Washington State Department of Transportation, http://www.wsdot.wa.gov/Projects/SR520/Pontoons. htm and https://www. flickr.com/photos/wsdot/6355256967/in/set-72157626065641731. 


\section{Chance Findings About Early Holocene Tidal Marshes of Grays Harbor, Washington, in Relation to Rapidly Rising Seas and Great Subduction Earthquakes}

By James B. Phipps, Eileen Hemphill-Haley, and Brian F. Atwater

Scientific Investigations Report 2015-5063

Version 1.1, May 2016 


\title{
U.S. Department of the Interior SALLY JEWELL, Secretary
}

\section{U.S. Geological Survey Suzette M. Kimball, Acting Director}

\author{
U.S. Geological Survey, Reston, Virginia \\ First release: June 2015 \\ Revised: May 2016 (ver. 1.1)
}

For more information on the USGS - the Federal source for science about the Earth, its natural and living resources, natural hazards, and the environment—visit http://www.usgs.gov or call 1-888-ASK-USGS.

For an overview of USGS information products, including maps, imagery, and publications, visit http://www.usgs.gov/pubprod/.

To order this and other USGS information products, visit http://store.usgs.gov

Suggested citation:

Phipps, J.B., Hemphill-Haley, E., and Atwater, B.F., 2015, Chance findings about early Holocene tidal marshes of Grays Harbor, Washington, in relation to rapidly rising seas and great subduction earthquakes (ver. 1.1, May 2016): U.S. Geological Survey Scientific Investigations Report 2015-5063, 36 p., http://dx.doi.org/10.3133/sir20155063.

Any use of trade, product, or firm names is for descriptive purposes only and does not imply endorsement by the U.S. Government.

Although this report, for the most part, is in the public domain, it may also contain copyrighted materials as noted in the text. Permission to reproduce copyrighted items must be secured from the copyright owners. 


\section{Acknowledgments and Author Roles}

During the dry-dock project, Tait Elder and Keith Syda of Jones \& Stokes helped process cores and Brian Christianson of Landau Associates shared samples and data. Rob Witter reviewed a short, early draft of this paper, written by Phipps, and encouraged its expansion. An expanded manuscript received insighful reviews from Stein Bondevik, Tom Cronin, Karen McKee, and Patricia McCrory. Hemphill-Haley made the diatom analyses, drafted the diatom figures, and developed alternatives to coseismic subsidence. Atwater prepared the remaining figures and most of the text. 


\section{Contents}

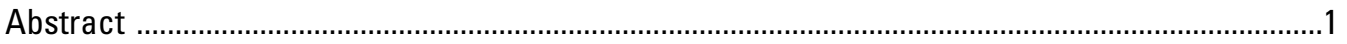

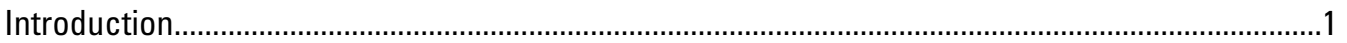

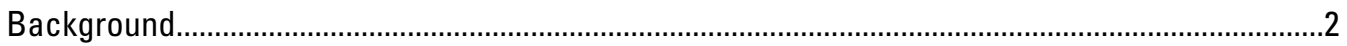

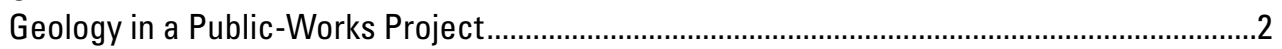

Effects of Rapid Submergence on Tidal Marshes ................................................................

Rapid Submergence in the Early Holocene.......................................................................

Sea-Level Jump from Drainage of Lake Agassiz....................................................................

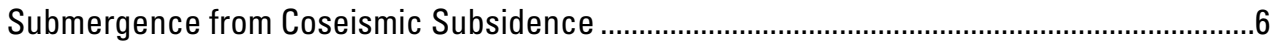

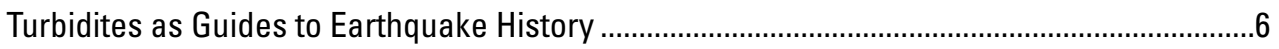

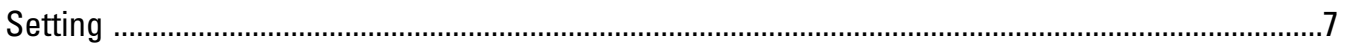

Methods

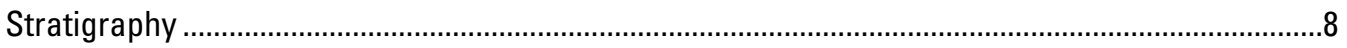

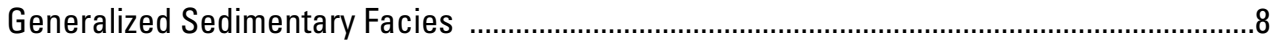

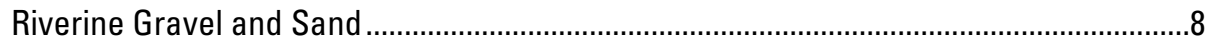

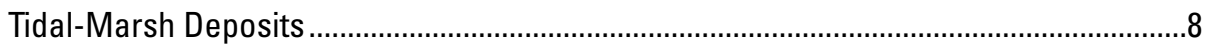

Thick Peaty Mud More Than 25 m Below Present Sea Level ....................................8

Higher, Thinner Bodies of Peaty Mud....................................................................

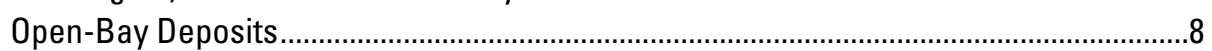

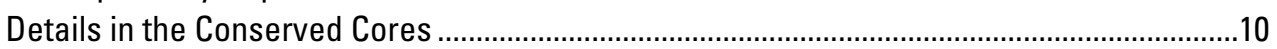

Physical Stratigraphy Across the Top of the Peaty Mud ..............................................10

Paleoecology Inferred from Microscopic Fossils .......................................................10

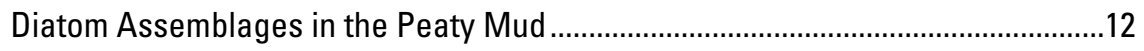

Diatom Assemblages Across the Top of the Peaty Mud..........................................14

Diatom Assemblages Higher in the Overlying Mud and Sand ................................21

Absence of Foraminifera Despite Presence of Bivalve Shells ..................................21

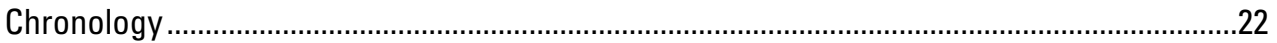

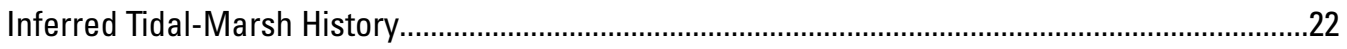

Earliest Holocene Tidal Marshes in the Dry-Dock Area ......................................................22

Lifespan of the Persistent Early Holocene Marshes ............................................................22

Demise of the Persistent Early Holocene Marshes ..............................................................23

Maximum Age Inferred from Radiocarbon Dating ..........................................................23

Evidence For and Against Erosion into the Top of the Thick Peaty Mud ........................23

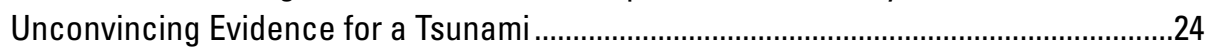

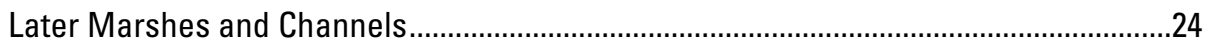

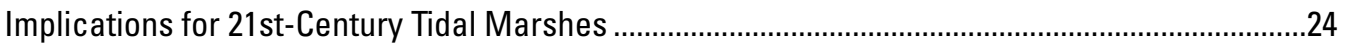

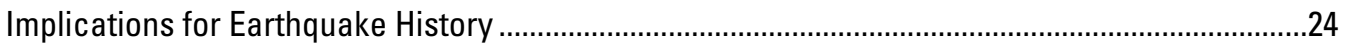

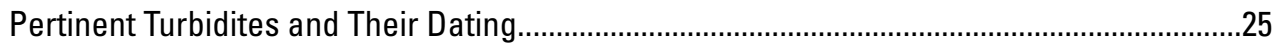

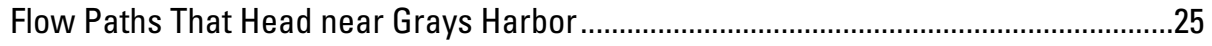

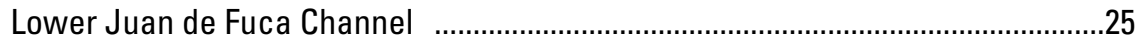

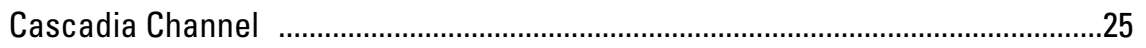

Composite Turbidite Sequence..................................................................................25

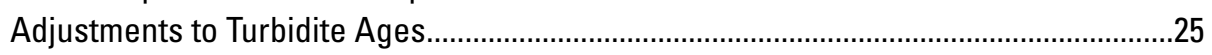

Reservoir Correction to Foraminiferal Ages........................................................28

Adjustments for Sample Thickness and Erosion ....................................................28

Limiting Ages from Reworked Mazama Ash .......................................................28

Offshore-Onshore Comparisons for the Interval $10,000-8,000$ cal yr B.P. ...............................28

Turbidites that May Correlate with Marsh Survival at Grays Harbor...............................28 
Turbidites of Lower Juan de Fuca Channel ............................................................28

Turbidites of Cascadia Channel.................................................................................29

Turbidites in the Composite Sequence......................................................................29

Turbidites that May Correlate with Marsh Demise at Grays Harbor................................29

Turbidite Evidence for an Unusually Large Earthquake .........................................30

Individual Turbidites of Lower Juan de Fuca Channel and Cascadia Channel ......30

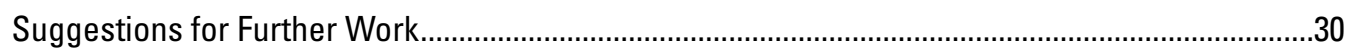

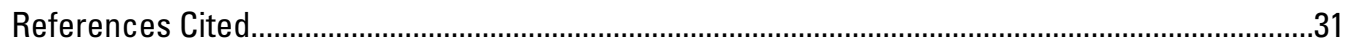

\section{Figures}

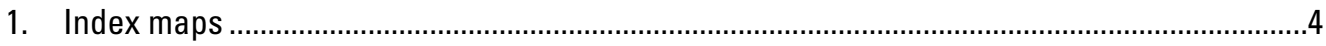

2. Generalized stratigraphy from logs of four dry-dock borings at Hoquiam and five at Aberdeen

3. Photographs of conserved core from boring $\mathrm{H} 1$, showing upward change from peaty mud to an overlying unit of mud and sand

4. Photographs of conserved core from boring $\mathrm{H} 2$, showing upward change from peaty mud to an overlying unit of mud and sand

5. Photographs of conserved core from boring $\mathrm{H} 3$, showing upward change from peaty mud to an overlying unit of mud and sand

6. Photographs of conserved core from boring $\mathrm{H} 4$, showing upward change from peaty mud to an overlying unit of mud and sand

7. Photographs of conserved core from boring $A 2$, showing upward change from peaty mud to an overlying unit of mud and sand

8. Photographs of conserved core from boring $A 5$, showing upward change from peaty mud to an overlying unit of mud and sand

9. Graphs of diatom concentrations and relative percentage of benthic and planktonic taxa in samples from borings $\mathrm{A} 5, \mathrm{H} 2$, and $\mathrm{H} 4$

10. Graphs showing proportions of diatom taxa that make up more than 5 percent of at least one sample across the top of the thick peaty mud in borings $\mathrm{A} 5, \mathrm{H} 2$, and $\mathrm{H} 4$

11. Photomicrographs showing diatoms from above and below the top of the peaty mud in boring $\mathrm{H} 4$

12. Photomicrographs showing diatoms from above and below the top of the peaty mud in boring A5.

13. Photomicrographs showing variation among diatom assemblages in silty sand that caps the thick peaty mud in cores $\mathrm{H} 1, \mathrm{H} 2$, and $\mathrm{H} 3$

14. Diagram summarizing sediment types and microfossil assemblages, four of the conserved core sections that span the tidal-marsh deposits dated to around 8,500 cal yr B.P.......20

15. Timelines for early Holocene marshes at Grays Harbor, deep-sea turbidites along the Cascadia Subduction Zones, and catastrophic drainage of glacial Lake Agassiz..........26

16. Diagrams illustrating hypothetical causes of the drowning and burial of early Holocene tidal-marsh deposits at Grays Harbor.

\section{Tables}

1. Radiocarbon ages from dry-dock cores at Grays Harbor .......................................................

2. Diatom data from Grays Harbor boreholes A5 (Aberdeen), and H2, $\mathrm{H} 4$ (Hoquiam) ..................21

3. Age estimates for early Holocene turbidites from deep-sea cores in Juan de Fuca Channel and Cascadia Channel 


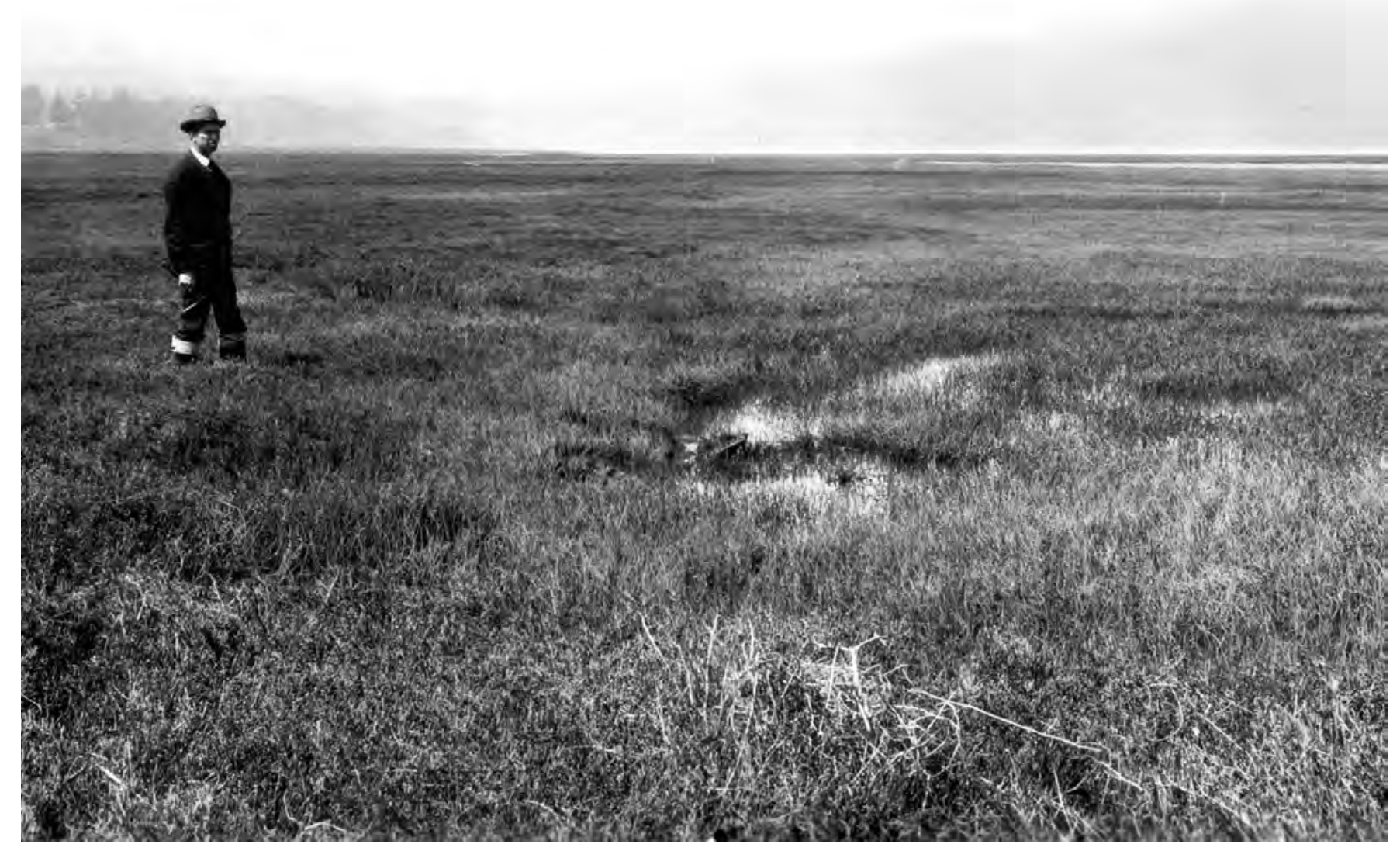

Photograph of a tidal marsh stressed by sudden rise in sea level relative to the land. The plants were found healthy in the darktoned area at left but dead or dying in the lighter-toned area at right. The view is northwestward along the San Andreas Fault at Bolinas Lagoon, California. The time is one year after this part of the fault ruptured during the 1906 San Francisco earthquake. The faulting caused the marshland at right, in a graben northeast of the fault, to drop. The downdrop amounted to an injurious rise in sea level for the marsh plants, which tolerate limited tidal submergence. Standing on the healthy marsh is Willis $\mathrm{L}$. Jepson (1867-1946), a botanist with the University of California, Berkeley. The photographer, U.S. Geological Survey geologist Grove Karl Gilbert, identified the main fault trace as passing between Jepson and the pool. Image ggk03055 at http://library.usgs.gov/photo/\#/ item/51dc6bece4b097e4d383778e. 


\title{
Chance Findings About Early Holocene Tidal Marshes of Grays Harbor, Washington, in Relation to Rapidly Rising Seas and Great Subduction Earthquakes
}

\author{
By James B. Phipps' ${ }^{1}$, Eileen Hemphill-Haley², and Brian F. Atwater ${ }^{3}$
}

\section{Abstract}

Tidal marshes commonly build upward apace with gradual rise in the level of the sea. It is expected, however, that few tidal marshes will keep up with accelerated sea-level rise later in this century. Tidal marshes have been drowned, moreover, after subsiding during earthquakes.

This report tells of ancient marshes that endured rapid sea-level rise in a region that subsides during earthquakes. The soils of these marshes were unexpectedly encountered in borings for a public-works project at Grays Harbor, Washington. The borings were logged quickly and only a few of the core sections were conserved. The limited findings pose puzzles about how the ancient marshes endured and what their history implies for earthquake hazards.

The borings establish that tidal marshes persisted during the early Holocene at Grays Harbor, an estuary along the Cascadia Subduction Zone of western North America. The persistent marshes are recorded by a unit of peaty mud up to $10 \mathrm{~m}$ thick and as much as $40 \mathrm{~m}$ below present sea level in the drowned valley of the Chehalis River. The unit was encountered in two areas $4 \mathrm{~km}$ apart that were tidal flats in the 19th century. The marshes originated less than 10,000 years ago and endured through most or all of an estimated 500-1,500 years.

The borings further show that these persistent marshes eventually yielded to tidal flats, tidal channels, or both. The change is marked by sand and mud that overlie the peaty mud at a typically sharp contact. The marshes were drowned about 8,600-8,400 years ago if the sand and mud buried them promptly, or later if the sand and mud filled channels that migrated across the peaty mud. In one of the studied areas, tidal marshes became re-established locally in the early Holocene and widely in the middle Holocene, and deposits of middle Holocene marshes were overrun as recently as 1,000 years ago by a gravelly tidal channel. In the other area, tidalflat and probably subtidal deposits make up all of the middle and late Holocene section below artificial fill; if marshes became re-established in this area after about 8,600-8,400 years ago, their deposits have been lost to erosion.

\footnotetext{
${ }^{1}$ Grays Harbor College

${ }^{2}$ Humboldt State University

${ }^{3}$ U.S. Geological Survey
}

The puzzles posed by these findings include: (1) How did the marshes manage to endure centuries of relative sea-level rise that likely approached $1 \mathrm{~cm} / \mathrm{yr}$ on average? (2) Did the marshes also endure subsidence that accompanied great thrust earthquakes on the Cascadia Subduction Zone? (3) Was their eventual drowning triggered by a Cascadia earthquake of unusually large size, or can the drowning be explained by sea-level rise that included a jump from drainage of glacial Lake Agassiz?

\section{Introduction}

A tidal marsh can survive gradual rise of the sea by building upward at a similar rate. Field evidence for this phenomenon was noticed more than 150 years ago by Benjamin Franklin Mudgea Massachusetts bank attorney, insurance agent, cemetery commissioner, and temperance advocate who later directed the Kansas Geological Survey (Parker, 1880). Examining the peaty soil of a Massachusetts salt marsh, Mudge found ancient saltgrass roots in growth position meters below their modern living counterparts. He concluded that the salt marsh had aggraded apace with what he interpreted as subsidence of the land beneath it. In modern terms, the sea had risen relative to the land - a relative sea-level rise, or submergence, at rates that averaged about $0.1 \mathrm{~cm} / \mathrm{yr}$ through most of the last few millenniums (Donnelly, 2006). This submergence was "so gradual that the growth of the plants has never been interrupted" (Mudge, 1862).

By the same token, a tidal marsh can succumb to submergence that happens suddenly. This effect was first reported at least a century ago. In 1906 the geologist Grove Karl Gilbert was tracing signs of surface rupture along the San Andreas Fault north of San Francisco. At Bolinas Lagoon he found that the marsh surface on one side of the fault trace had dropped a few tenths of a meter during the earthquake. Revisiting the marsh one year later, accompanied by the botanist Willis L. Jepson, Gilbert found the marsh plants dead and dying on the down-dropped side but unaffected on the other (opposite page). "The contrast was so strong that the eye could readily trace the line of the fault" (Gilbert, 1908, p. 81).

This report describes an instance in which tidal marshes above an active fault survived rapid submergence for centuries yet eventually drowned. The persistent marshes are evidenced 
by thick soil encountered tens of meters below present sea level in borings for a public-works project at Grays Harbor, a Pacific coast estuary in Washington State (fig. 1). The marshes persisted for perhaps a millennium in a part of postglacial time when sea level was rising rapidly - about as fast as it may later in this century. But the marshes succumbed around $8,500 \mathrm{cal}$ yr B.P. ${ }^{1}$ or soon thereafter, and they were replaced by tidal flats, tidal channels, or both.

The report contains sections about background, new observations, and mainly earthquake-related interpretations. The background text introduces the public-works project, the main geologic issues to be discussed, and the study area. The new observations include a generalized stratigraphic cross section from correlated borings (fig. 2), photographs of several conserved core sections (figs. 3-8), diatom assemblages and paleoecology of these core sections (figs. 9-14), and radiocarbon ages on wood and marsh soil that set limits on when the persistent marshes became established and when they were drowned (fig. 15). The interpretations focus on whether the persistent marshes endured earthquakes that are evidenced offshore, and whether the top of the deposits of these marshes marks an unusually large earthquake or can be explained instead by some combination of drainage of an ice-dammed lake, local changes in sediment supply, and migration of tidal channels (fig. 16).

\section{Background}

\section{Geology in a Public-Works Project}

Construction projects can open windows into Earth history. Aerial photography required for hydropower and irrigation works of the U.S. Bureau of Reclamation serendipidously provided evidence that strengthened the case for ice-age floods in eastern Washington (Bretz and others, 1956). The building of nuclear power plants for the Washington Public Power Supply System (Pope, 2008) occasioned seismological studies that hastened recognition of great-earthquake hazards along the Cascadia Subduction Zone (Doughton, 2013). The Federal-Aid Highway Act of 1956 gridded the United States with roadcuts for interstate highways - "Make a fresh roadcut almost anywhere at all and geologists will close in swiftly, like missionaries racing anthropologists to a tribe just discovered up the Xingu" (McPhee, 1998).

The stratigraphy in this report was brought to light by preparatory work for an unusual construction project of the Washington State Department of Transportation. Three state highways in the Puget Sound area cross fjord-like waters on bridges supported by pontoons. A dozen years ago, one floating

\footnotetext{
${ }^{1}$ Ages in cal yr B.P. have been derived from radiocarbon dating. The "cal" denotes "calibrated," connotes "calendar," and signifies adjustment for temporal variation in the atmospheric production of ${ }^{14} \mathrm{C}$. Table 1 illustrates this adjustment. The ages were measured in radiocarbon years $\left({ }^{14} \mathrm{C}\right.$ yr B.P.). The "B.P." in both units means before present, where "present" is 1950.
}

bridge needed new pontoons and another floating bridge was slated for replacement. The pontoons were to be built below sea level in a waterfront dry dock, floated upon opening of its gates, and towed to the bridge sites.

The department first sought to build the dry dock in Port Angeles (for location, see fig. $1 \mathrm{~A}$ ). Soon after construction began there in 2003, backhoes unearthed middens and burials of Tsewhit-zen, a Native American village (Mapes, 2009; Wegmann and others, 2012). In 2004 the department ended construction with a loss of nearly $\$ 90$ million (MacDonald, 2006, p. 213). An ensuing appraisal for the State legislature advised department officials to consider site archaeology in the geologic context of landscapes from the past 10,000 years (Hudak and others, 2006).

When the department next sought a dry-dock site at Grays Harbor, the archaeological surveys included continuous coring through tens of meters of Holocene deposits. An archaeological firm hired one of us (Phipps) to log the core samples in search of buried land surfaces on which cultural remains might be found. The borings were sited in $\log$ yards on what had been 19th-century tidal flats in Aberdeen and Hoquiam (fig. 1E,F). In core samples logged by Phipps in 2009, deeply buried remains of Holocene tidal marshes were found, but no middens or cemeteries associated with these former land surfaces, nor any cultural materials in underlying riverine deposits of probable Pleistocene age (fig. 2). The Aberdeen site was selected, construction of the dry dock was underway early in 2011 (cover photo), and pontoons were first towed from the site in 2012.

In this roundabout manner, a public-works project provides a glimpse of the early postglacial history of one of the largest Pacific coast estuaries along the Cascadia Subduction Zone. Our descriptions of the estuarine stratigraphy are founded on the logging by Phipps in 2009 (fig. 2), and our dating of the stratigraphic units relies on radiocarbon ages that were obtained in further support of the archaeological site assessment (table 1). Our interpretations of marsh survival and demise are limited by geology's secondary role in the archaeological work and by failure of Atwater and Phipps to conserve more cores than the few shown in figures $3-8$.

\section{Effects of Rapid Submergence on Tidal Marshes}

Sea level is likely to rise an average of $0.2-1.2 \mathrm{~cm} / \mathrm{yr}$ in this century, in contrast with the average submergence rates close to $0.1 \mathrm{~cm} / \mathrm{yr}$ that have prevailed on many coasts in recent millenniums (Willis and Church, 2012; Hinkel and others, 2014). This accelerated rise, already underway, has led to concern that tidal marshes will drown (Kintisch, 2013). The marshes seen as in jeopardy include wetlands created or rehabilitated to compensate for environmental damage, or to provide habitat and food for endangered species.

Forecasts for 21 st-century tidal marshes commonly rely on computer simulations in which vertical marsh accretion competes with submergence (Mudd and others, 2009; Kirwan and others, 2010; Fagherazzi and others, 2012; Glick and others, 2013; Takekawa and others, 2013; Schile and others, 2014). The marsh may build up as suspended sediment settles out of tidal 
water, above-ground parts of the plants fall to the ground, and roots and rhizomes (below-ground stems) expand the marsh soil. But the build-up may fail to overcome concurrent sinking, relative to the sea, as organic matter in the soil decomposes, soft sediments beneath the soil consolidate, and sea levels rise.

Examples from California, Louisiana, and Hokkaido show how actual marshes have responded to rapid submergence. In California, tidal marshes survived fast 20th-century submergence at southern San Francisco Bay (Patrick and DeLaune, 1990; Watson, 2004), where groundwater overdraft had led to a few decades of land subsidence averaging $1-2 \mathrm{~cm} / \mathrm{yr}$ (Galloway and others, 1999, p. 18). In Louisiana, several kinds of subsidence are contributing to rapid land loss on the Mississippi River Delta (Yuill and others, 2009; Couvillion and others, 2011), where modern submergence rates widely average 1-2 cm/yr and modern marsh accretion rates approach $1 \mathrm{~cm} / \mathrm{yr}$ (Glick and others, 2013, p. 218-220). In eastern Hokkaido, tidal marshes shifted landward in response to late 20th-century submergence that averaged $0.8-0.9 \mathrm{~cm} /$ yr at two tide gauges (Sawai and others, 2004). This chronic submergence included, during 1993-2010, a regional component of about $0.5 \mathrm{~cm} / \mathrm{yr}$ detected by satellite (Meyssignac and Cazenave, 2012). Some of the Hokkaido marshes shifted landward: tidal flat replaced old marsh, while new marsh invaded fringing forests (Atwater and others, 2004a).

Borings for the dry-dock project encountered tidal-marsh deposits from an ancient time when sea level on most coasts was rising nearly $1 \mathrm{~cm} / \mathrm{yr}$ on average. These deposits provide evidence below that early Holocene marshes at Grays Harbor managed, for an estimated 500-1,500 years, to keep up with submergence that was about as fast as in projections for 21st-century sea levels.

\section{Rapid Submergence in the Early Holocene}

During the period $10,000-8,000$ cal yr B.P., relative sea level rose, on average, $1 \mathrm{~cm} / \mathrm{yr}$ on most shores worldwide that had not been covered by Pleistocene ice sheets (Cronin, 2012). The documented examples include Barbados, Tahiti, and Papua New Guinea (reviewed by Smith and others, 2011, their figure 4A), the Netherlands (Hijma and Cohen, 2011, p. 1457-1458), and Chesapeake Bay. The submergence at Chesapeake Bay averaged close to $1 \mathrm{~cm} / \mathrm{yr}$ in the interval $9,500-7,500 \mathrm{cal}$ yr B.P. and $1.2 \mathrm{~cm} / \mathrm{yr}$ around $8,950-8,750 \mathrm{cal}$ yr B.P. and 8,200-7,600 cal yr B.P. (Cronin and others, 2007).

At Grays Harbor, submergence during 10,000$8,000 \mathrm{cal}$ yr B.P. may have been moderated by gravitational effects of land-ice loss. Today's losses of land ice in Alaska and Greenland are moderating sea-level rise in Washington by reducing the gravitational pull between these wasting ice masses and the northeast Pacific Ocean. The lost attraction offsets an estimated one-third of the sea-level rise from the Alaska and Greenland meltwater (Committee on Sea Level Rise in California, Oregon, and Washington, 2012, p. 78-82). A similar gravitational effect may have diminished, in Washington, the sea-level rise from early Holocene wasting of the Laurentide Ice Sheet.
Early Holocene submergence at Grays Harbor should have been moderated also by temporary uplift during the centuries between great thrust earthquakes on the Cascadia plate boundary. Tectonic-plate convergence at the Cascadia Subduction Zone causes interseismic uplift by shortening the overriding North America Plate (Burgette and others, 2009). This uplift reduces the submergence rate by a few millimeters per year, as judged from the 20th-century uplift rates that Ando and Balazs (1979) inferred from leveling and tide-gauge data.

Across millenniums, however, this uplift between earthquakes is negated by lowering of the land during earthquakes (Thatcher, 1984; Atwater, 1987; Kelsey and others, 1994). The result in western Washington is a residual, or net uplift, shown by Pleistocene marine terraces, that averages just a few tenths of a millimeter per year across the past 100,000 years or so (West and McCrumb, 1988).

In the late Holocene, coseismic subsidence has affected tidal marshes at Grays Harbor more obviously than has interseismic uplift or net uplift. For the marshes, the subsidence yields an instantaneous relative sea-level rise that in some instances has amounted to $1 \mathrm{~m}$ or more (see section below on submergence from coseismic subsidence, p. 6). We therefore consider coseismic subsidence as the prime suspect in the eventual demise of early Holocene tidal marshes at Grays Harbor.

\section{Sea-Level Jump from Drainage of Lake Agassiz}

Rapid early Holocene submergence at Grays Harbor probably included a sea-level jump from a drainage of glacial Lake Agassiz in Canada. During this drainage, dated most directly to the interval $8,500-8,000 \mathrm{cal}$ yr B.P., lake water escaped to the Atlantic Ocean by passing beneath remains of the Laurentide Ice Sheet (Lewis and others, 2012). The estimated volume of the outburst is as much as $163,000 \mathrm{~km}^{2}$ (Leverington and others, 2002).

A sea-level jump from Lake Agassiz drainage has been linked to submergence on several coasts. They include Chesapeake Bay, where tidal marshes downed 8,200-7,600 cal yr B.P. (Cronin and others, 2007), and the northern Gulf of Mexico, where bay-head deltas retreated around 8,200 cal yr B.P. (Törnqvist and others, 2004; Rodriguez and others, 2010).

In the Netherlands, stratigraphic evidence for a 4-m sealevel jump has been assigned to a two-century interval in the time window between 8,600 and 8,300 cal yr B.P. (Hijma and Cohen, 2010). Hijma and Cohen ascribed half this jump to a background sea-level rise of $1 \mathrm{~cm} / \mathrm{yr}$ and the other $2 \mathrm{~m}$ to a combination of Agassiz drainage and Antarctic Ice Sheet melt. They went on to propose that the jump would be expressed as a "transgressive contact in foreshore and coastal prism sequences worldwide" (Hijma and Cohen, 2011, p. 1479).

These expectations from the Netherlands may be excessive, both globally and at Grays Harbor, for several reasons:

1. In a model of global effects on sea level, in which a Lake Agassiz outburst of $140,000 \mathrm{~km}^{3}$ has an average sealevel equivalent of $0.4 \mathrm{~m}$, the resulting sea-level rise in 


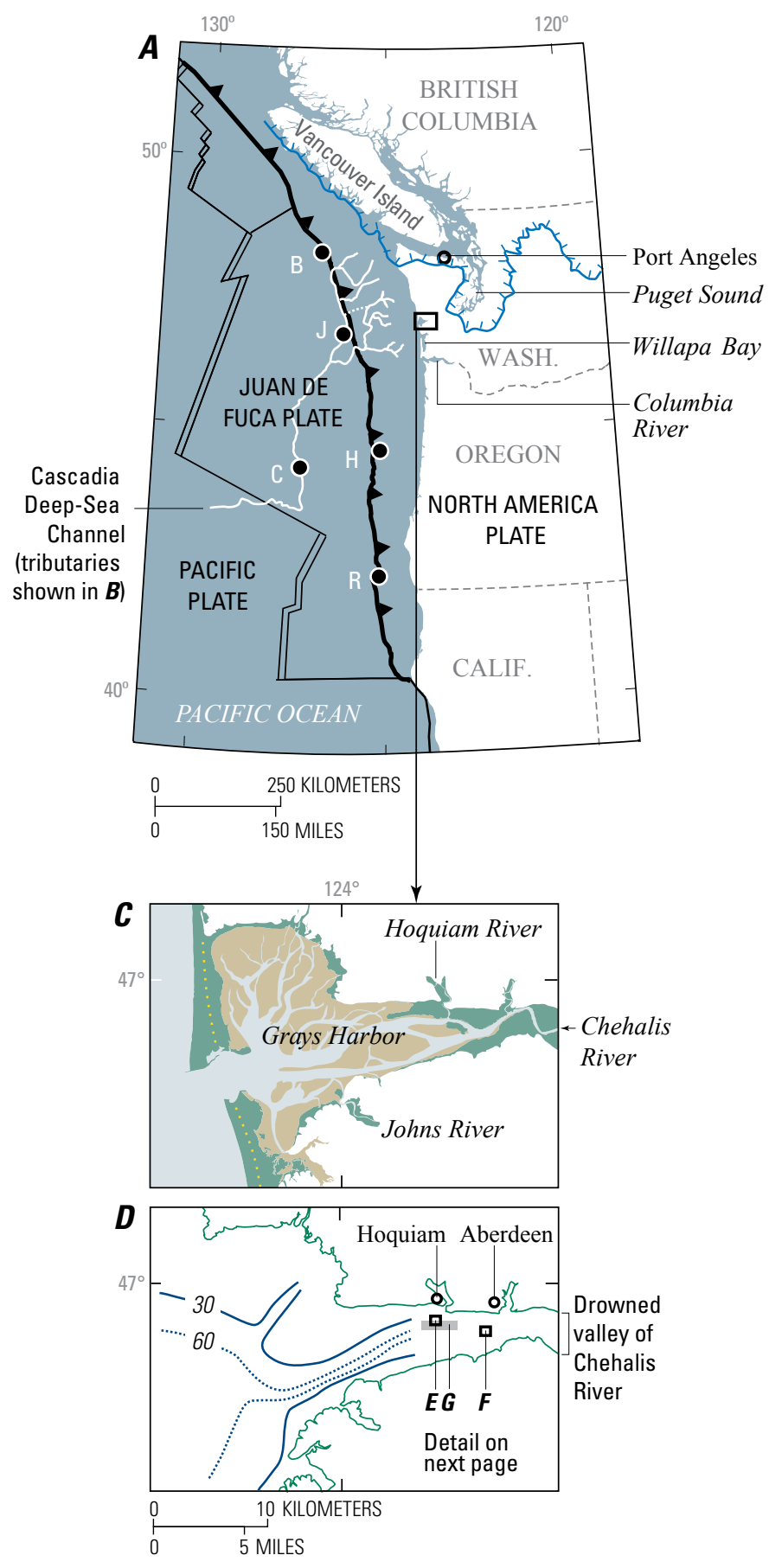

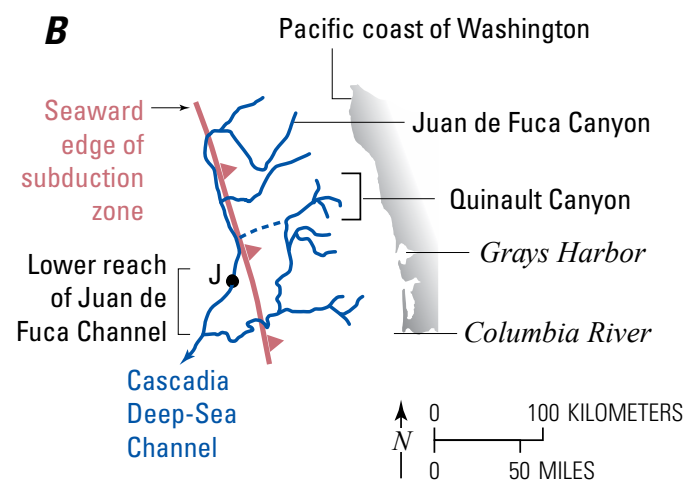

EXPLANATION

Symbols in $\boldsymbol{A}$

Seaward edge of subduction zone

Spreading ridge

Southern limit of Pleistocene ice sheet

- Deep-sea cores

Flow paths in $B$

_..- Channel thalweg

Historical landforms in $C$

Beach-ridge plain

Tidal marsh and tidal swamp

Tidal flat

Holocene deposits in $D$

Landward limit of historical tidesMostly inland of bay shore

-....6 60 Depth to base, in meters below sea level

\section{Symbols in $E$ and $F$}

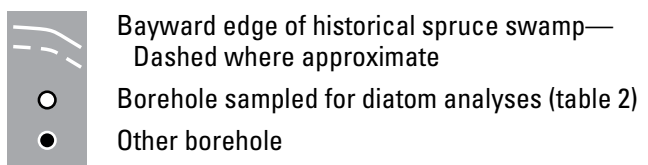

Bottom-sediment type reported by hydrographers in $\boldsymbol{G}$ Gravel

Sand

Mud

Figure 1. Index maps. Explanations grouped below B. (A) Cascadia Subduction Zone. Ice-sheet limit from Clague (1983). Deep-sea core sites, from Goldfinger and others (2012, p. 6): B, Barkley; J, Juan de Fuca; C, Cascadia; H, Hydrate Ridge; R, Rogue. (B) Sketch map of potential flow paths for turbidity currents that originate offshore Washington. Dashed spillover path proposed by Atwater and others (2014). (C) Grays Harbor. The tidal flats and channels, mapped by a 19th-century hydrographic survey at 1:20,000 scale (Bolles and others, 1883), were traced from the area's earliest nautical chart (U.S. Coast and Geodetic Survey, 1928). Areas shaded green include sand spits west of Grays Harbor, tidal marshes and tidal spruce swamps, and filled tidal flats. (D) Contoured depths to the buried Chehalis River valley inferred by Peterson and Phipps (1992) from cores and seismic-reflection profiles. (E,F, next page) Sites of dry-dock borings on filled tidal flats. Northern limit of historical tidal flat from 1:10,000-scale survey (Rude and Smith, 1911); line dashed where flat had been filled by 1911. ( $G, H$, next page) Depths and bottom sediment of tidal channel south of Hoquiam as surveyed late in the 19th century (Bolles and others, 1883). The graph $(\boldsymbol{H})$ shows the greatest measured depth along each diagonal line of soundings. 
the Cascadia region is only $0.2 \mathrm{~m}$ (Kendall and others, 2008). Much like the wasting of modern ice in Alaska and Greenland, emptying the lake reduces eastward gravitational pull on the northeast Pacific Ocean, which then recedes slightly from the Pacific coast of Washington.

2. A $0.2-\mathrm{m}$ rise is no larger than some of the modern multi-year swings in mean sea level on Cascadia shores that are driven largely by the El Niño Southern Oscillation (Komar and others, 2011; Committee on Sea Level Rise in California, Oregon, and Washington, 2012).
3. An estimated sum of all early Holocene outbursts is equivalent to a global sea-level rise of $0.6 \mathrm{~m}$ (Smith and others, 2011, p. 1850).

4. A 2-m global sea-level rise is equivalent to the estimated net loss of ice in the Antarctic for the entire time between 10,000 and 5,000 cal yr B.P. (Whitehouse and others, 2012, their figure 7a).

We view a Lake Agassiz jump as one of the potential contributors to marsh drowning at Grays Harbor (fig. 16), but we expect the jump to have been smaller than the subsidence that often accompanies plate-boundary earthquakes along the Cascadia Subduction Zone.

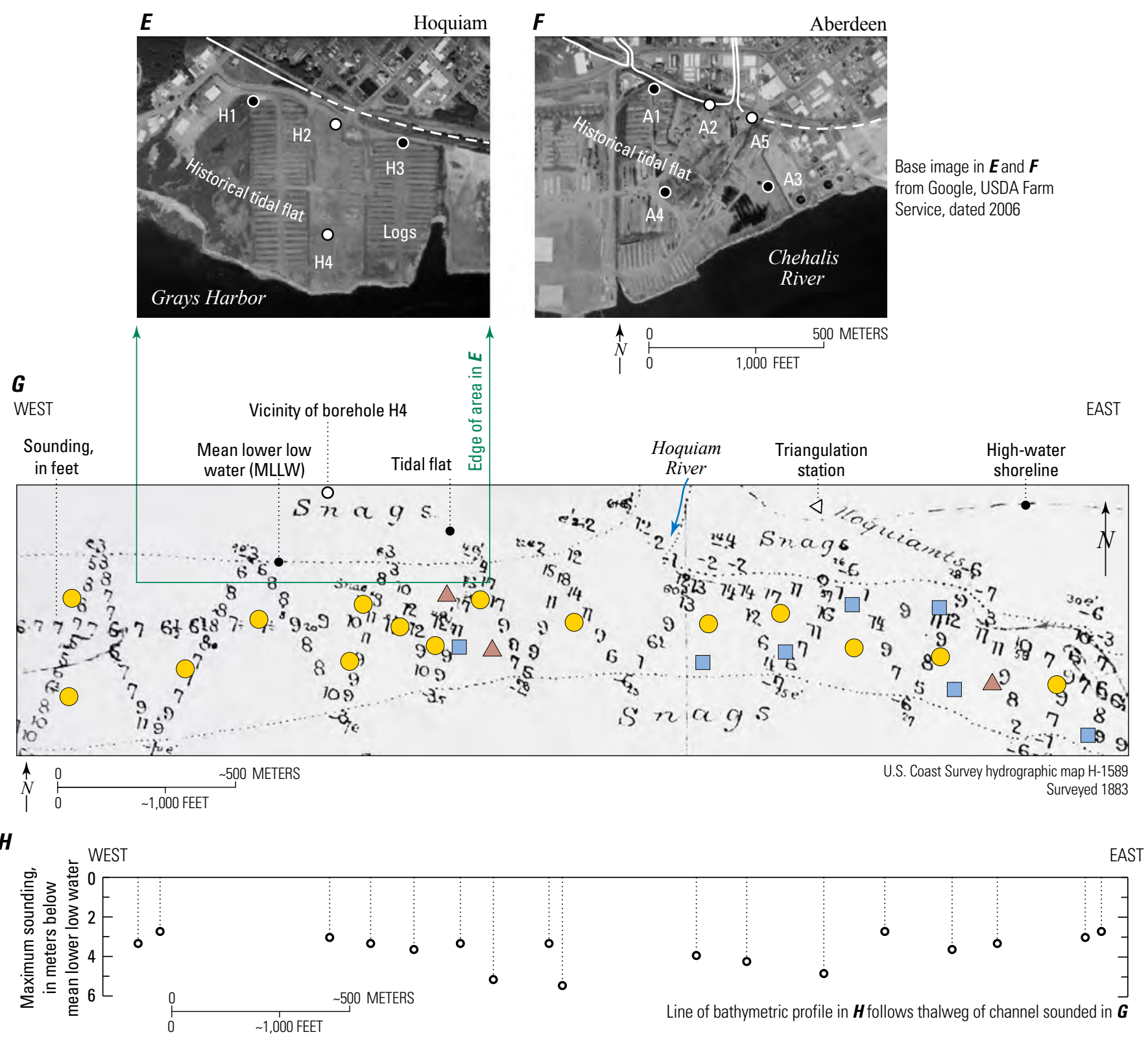




\section{Submergence from Coseismic Subsidence}

Vegetated lowlands became tidal flats in the aftermath of the giant thrust earthquakes of 1960 in Chile and 1964 in Alaska. In both cases, local coasts were lowered by as much as $2.3 \mathrm{~m}$ when tens of meters of sudden displacement on the plateboundary thrust stretched and thinned the overriding tectonic plate (Plafker, 1969; Plafker and Savage, 1970).

Estuarine stratigraphic records of these land-level changes in Chile and Alaska vary with sediment supply. At a sediment-starved estuary in Chile, pastures that became bare tidal flats in 1960 remained unvegetated decades later. Subsided pasture soils from 1960 were still being stripped by wind waves at high tide, burrowed by crabs and worms, and mantled only locally by lenses of recycled sand (Cisternas and others, 2005). At a sediment-rich estuary in Alaska, by contrast, subsided lowland soils were covered by a meter of tidal rhythmites in the first months after the 1964 earthquake. Meadows and willow thickets became reestablished by 1973 and spruce groves by 1980 (Ovenshine and others, 1976; Atwater and others, 2001).

At Grays Harbor, late Holocene tidal marshes and tidal swamps have undergone sudden drowning and gradual rebuilding in sawtooth cycles punctuated by great earthquakes on the Cascadia Subduction Zone. This active plate boundary, which slants beneath the Pacific coast between southern British Columbia and northern California (fig. 1A), used to be thought aseismic (Ando and Balazs, 1979) but is now widely acknowledged as a great-earthquake source (Hyndman and Rogers, 2010). The buried remains of subsided marshes and swamps attest to aperiodic recurrence of great Cascadia earthquakes at Grays Harbor and vicinity. In the past 3,500 years, the inferred recurrence intervals averaged about 500 years and ranged from a few centuries to a millennium (Atwater and others, 2004b).

The most recent great Cascadia earthquake, in January 1700 (Satake and others, 1996; Satake and others, 2003), was accompanied by tectonic subsidence at most bays and river mouths along the Pacific coast between southern British Columbia and northern California (Atwater and others, 1995). In tidal wetlands along the Chehalis River (fig. $1 C$ ), Sitka spruce forests became tidal flats in 1700 but new spruce were sprouting by the late 1700 s, and the tidal swamp today is ready to record the next earthquake (Benson and others, 2001). Postearthquake deposits filled intertidal space that the subsidence in 1700 had created.

Dissimilar amounts of coseismic subsidence at Grays Harbor have been estimated for eight buried soils of the past 5,000 years along the Johns River (location on fig. $1 C$ ). The amounts are about $1.5 \mathrm{~m}$ for one soil, $0.5-1.5 \mathrm{~m}$ for each of four soils (including the one marking the 1700 earthquake), and less than $0.5 \mathrm{~m}$ for each of three soils. The estimates are based on changes in diatom and pollen assemblages between the buried soil (representing the pre-earthquake land level) and overlying mud (representing the post-earthquake land level) (Shennan and others, 1996). The assemblages were calibrated to modern diatoms and pollen of Johns River wetlands. From the upland-forest edge to the lower limit of pioneer colonists of tidal flats, tidal-marsh vegetation spans a vertical range of $1.0-1.5 \mathrm{~m}$ in southern coastal Washington, and most of the marsh is a plain at or slightly above mean higher high water (Atwater and Hemphill-Haley, 1997, p. 11-14).

As at Grays Harbor, estimated amounts of coseismic subsidence also differ nearby among seven successive buried soils from the past 3,500 years that are exposed at nearby Willapa Bay (Atwater and Hemphill-Haley, 1997, p. 96; Atwater and others, 2004b). At one extreme, the land subsided just enough to change high tidal marshes into low tidal marshes, as judged from fossil diatoms. At the other extreme, unvegetated tidal flats replaced tidal marshes and tidal spruce swamps in 340-410 C.E. and again in 1700 C.E. The subsidence in 1700 at Willapa Bay likely exceeded $1 \mathrm{~m}$ (Hemphill-Haley, 1995; Atwater and Hemphill-Haley, 1997, p. 48), notwithstanding a recent estimate of $0.5 \mathrm{~m}$ or less (Wang and others, 2013).

We use this late Holocene history of variable but recurrent submergence in southwest Washington as reason to puzzle over the persistence of early Holocene marshes at Grays Harbor, to consider whether coseismic subsidence initiated their demise, and to review deep-sea turbidites as guides to early Holocene earthquake history along the Cascadia Subduction Zone.

\section{Turbidites as Guides to Earthquake History}

Subaqueous deposits can provide paleoseismological records that are long and unbroken. In Chilean lakes, turbidites intercalated with annually laminated deposits are clarifying subduction-earthquake history of the past 900 years (Moernaut and others, 2014). In Switzerland, lake-bottom slumps and turbidites provide evidence for earthquakes from the past 10,000 years or more (Strasser and others, 2013). An 18,000year earthquake history has recently been inferred from deepsea turbidites off New Zealand (Pouderoux and others, 2012).

Deep-sea turbidites along the Cascadia Subduction Zone provide the main basis for a comprehensive earthquake history proposed for the past 10,000 years (Goldfinger and others, 2012). This reconstruction underpins tsunami scenarios (Priest and others, 2010), fault-energy budgets (Goldfinger and others, 2013), estimates of giant-earthquake probability (Kulkarni and others, 2013), and a method for estimating maximum earthquake magnitude (Rong and others, 2014).

Turbidite paleoseismology originated with a reinterpretation of the deposits of turbidity currents that were triggered off the coast of Washington (Adams, 1990). The turbidity flows were inferred to have originated above areas where the plate-boundary megathrust ruptured. The flow paths were assumed to be confined to canyons and channels (solid lines, fig. $1 B$ ), and the turbidites were assumed to correspond almost one-for-one with earthquakes of interest. These assumptions were recently questioned, chiefly on the basis of cores collected off Washington in the late 1960s and early 1970s (Atwater and others, 2014). 
In a test of turbidite paleoseismology at Cascadia, Goldfinger and coworkers (2012, p. 100-101) compared their proposed 10,000-year history, derived from deep-sea evidence, with geologic histories of coastal subsidence and tsunamis. In most of the comparisons the coastal histories span the past 5,000 years at most, and in none does the coastal history go back more than 6,500 years. This limitation in the coastal evidence can be seen in the review by Leonard and others (2010). The limitation reflects a link to relative sea levels in the region. Nearly all the coastal evidence is tied to buried soils of tidal wetlands (tidal marshes or tidal swamps), which serve as datums for detecting coseismic subsidence, as surfaces overrun by tsunamis, or both. Tidal-wetland soils that are of late Holocene age are easier to find for two reasons. First, deceleration of relative sea-level rise in the late Holocene probably helped tidal wetlands to spread. Second, only in the late Holocene have sea levels been high enough to produce tidal-wetland soils that are exposed at low tide in banks of tidal creeks, or that can be reached in hand-driven cores that rarely go deeper than $5 \mathrm{~m}$.

The borings for the Grays Harbor dry-dock project, by reaching depths of $40 \mathrm{~m}$ below modern sea level, sampled Holocene tidal-wetland deposits older than any previously used in paleoseismology along the Cascadia Subduction Zone. These deposits record the persistence and eventual demise of marshes $10,000-8,000$ cal yr B.P, an early chapter in the Cascadia earthquake history that has been inferred from deep-sea turbidites. We will ask whether Cascadia earthquakes inferred from turbidites failed to drown the persistent marshes at Grays Harbor, and whether an earthquake inferred to have been unusually large coincided with the eventual demise of these marshes.

\section{Setting}

The area of Grays Harbor includes a former reach of the Chehalis River (fig. 1C,D). During the last glaciation the lower Chehalis River valley conveyed outwash from the lobe of the Cordilleran ice sheet that occupied the Puget Sound lowland (Bretz, 1913). The Puget lobe reached its last-glacial limit about 17,000 cal yr B.P. and retreated from the lowland in the first centuries thereafter (Porter and Swanson, 1998).

The Grays Harbor area underwent little of the postglacial rebound that dominated initial relative sea-level changes in the formerly glaciated areas to its north (Shugar and others, 2014). Those formerly glaciated areas include southern Vancouver Island, where relative sea level initially fell in response to glacioisostatic uplift, reached a minimum about $25-35 \mathrm{~m}$ below modern sea level around 11,500 cal yr B.P., and approached its present position by 6,000 cal yr B.P. (James and others, 2009). The rapid uplift of southern Vancouver Island was limited to the first millenniums after deglaciation, and glacioisostatic models predict present-day subsidence in Washington (James and others, 2000).

The documented sedimentary record of postglacial submergence at Grays Harbor begins about 10,000 cal yr
B.P. The landscape that was submerged included a westward extension of the Chehalis River valley that Peterson and Phipps (1992) identified in boreholes and seismic-reflection profiles (fig. 1D) and which McCrory and others (2002) traced across the continental shelf. The deepest post-glacial fill rests on fluvial gravel and consists mainly of sand and mud of marine provenance (Peterson and Phipps, 1992). Modern sand in the upper bay, near Hoquiam and Aberdeen, is derived from the Chehalis River, while the sand farther west, within $11 \mathrm{~km}$ of the sea, was derived from the Columbia River and was moved northward on the continental shelf (Scheidegger and Phipps, 1976). Sand and silt of Columbia River provenance form a northward-thinning deposit on much of the continental shelf off Washington (Nittrouer, 1978; Wolf and others, 1999; Twichell and Cross, 2001), while sand of local provenance predominates on the inner continental shelf north of Grays Harbor (Venkatarathnam and McManus, 1973).

The dry-dock borings used in this report penetrated Holocene and latest Pleistocene deposits beneath two diked, landfilled areas - one in Hoquiam (H boreholes), the other in Aberdeen (A boreholes) (fig. 1E,F). Both areas were tidal flats in 1883, when Grays Harbor's tidal channels were first sounded in detail (fig. $1 C, G, H$ ). A channel that fronted the Hoquiam area was $0.5 \mathrm{~km}$ wide and as much as $6 \mathrm{~m}$ deep at low tide, and its bed was made of sand, mud, and local gravel (fig. 1G). By 1911 the two areas had been "[b]uilt up of sawdust and scraps of lumber" (Rude and Smith, 1911). The areas were log-sorting yards by century's end.

\section{Methods}

The stratigraphy plotted in figure 2 summarizes logs of sonic cores obtained for the dry-dock project. A truck-mounted drill rig used high-frequency vibrations to obtain samples $7.5 \mathrm{~cm}$ in diameter and $1.5 \mathrm{~m}$ or $3 \mathrm{~m}$ in length to depths of $35-43 \mathrm{~m}$ below ground surface. The sampling ranged from nearly continuous (boreholes H3 and A1-A3, fig. 2) to sparse (A5). Each core sample was kept in a rigid plastic tube until cut in half and logged under natural light. Most samples were discarded after logging if they lacked cultural material.

Project surveyors measured the ground-surface elevation at each borehole site to the nearest $0.1 \mathrm{~m}$ or less. They referenced the elevations to mean lower low water, which is $1.7 \mathrm{~m}$ below mean sea level at Aberdeen (http:// tidesandcurrents.noaa.gov/benchmarks/9441187.html).

The archaeological assessment included radiocarbon dating of plant fragments in sand and gravel and on bulk peaty mud (the ten Beta ages in table 1). We obtained one additional age on peaty mud (the NOSAMS age, table 1). We converted all ages to cal yr B.P. with the calibration program Calib 6.0.1 and the calibration dataset IntCal09 (Reimer and others, 2009).

Phipps set aside one core segment as much as $1.5 \mathrm{~m}$ long from each of six boreholes (H1-H4, A2, A5; figs. 3-8). Each conserved segment spans the top of the thickest peaty 
mud. All were sampled in 2010 by Hemphill-Haley for examination of microscopic fossils. She analyzed a total of 24 samples quantitatively for diatoms in cores $\mathrm{H} 2, \mathrm{H} 4$, and $\mathrm{A} 5$ and a number of additional samples qualititatively in $\mathrm{H} 1, \mathrm{H} 2$, H3, H4, A2, and A5 (table 2, figs. 9-14). She also separately prepared and checked splits of samples for the presence of foraminifera (fig. 14).

\section{Stratigraphy}

The Hoquiam boreholes resemble the Aberdeen boreholes in overall stratigraphic sequence. Fluvial gravel and sand underlie a few tens of meters of estuarine deposits, which in turn are capped by artificial fill. The lower part of the estuarine section is dominated by peaty mud of tidal marshes, and the higher part consists mainly of mud, sand, and minor gravel that record lower intertidal and subtidal conditions. The estuarine deposits postdate $10,000 \mathrm{cal}$ yr B.P., and most of the tidal-marsh deposits predate $8,600-8,400$ cal yr B.P.

These generalizations refer to the stratigraphic cross section of correlated cores in figure 2 and to the radiocarbon ages that are listed in table 1 and graphed in parts $A$ and $B$ of figure 15 . The conserved core sections are pictured in figures 3-8. Table 2 summarizes key parameters of the diatom analyses from these sections. The diatom assemblages themselves are depicted in figures 9-14.

\section{Generalized Sedimentary Facies}

\section{Riverine Gravel and Sand}

The basal gravel and sand probably represent an ancestral Chehalis River. The gravel, encountered at depths of 30-40 m below present sea level, includes recovered cobbles as much as $6 \mathrm{~cm}$ in diameter and likely represents river channels. This gravel is commonly capped by sand and silt that may represent riverine point bars and floodplains (fig. 2). The persistent early Holocene tidal marshes originated on top of this sand and silt.

\section{Tidal-Marsh Deposits}

\section{Thick Peaty Mud More Than 25 m Below Present Sea Level}

Peaty mud of tidal marshes was found mainly in the depth range $25-40 \mathrm{~m}$ below present sea level. Its thickness there is nearly $10 \mathrm{~m}$ in most of the Hoquiam cores and less in the Aberdeen cores. It was logged as a single uninterrupted unit in some cores $(\mathrm{H} 2, \mathrm{H} 4)$ but contains conspicuously organic-poor intervals in others $(\mathrm{H} 3, \mathrm{~A} 1, \mathrm{~A} 3)$ and is mostly absent in still another (A2).

The thick peaty mud ranges from structureless to distinctly layered in the conserved samples (figs. 3-8). The layers, commonly $1 \mathrm{~cm}$ thick, are marked by their organic caps, and in some core sections the layers repeat rhythmically (figs. 4, 6). The rhythmic layers may be annual; annual couplets have been reported from tidal-marsh deposits in Great Britain (Allen, 1990, p. 89-90).

Organic content evidenced by brown color diminishes downward, overall, in two of the conserved core sections (figs. 3, 6). We doubt that this trend continues through the thick unit as a whole.

Plant remains visible to the naked eye in the conserved cores include decomposed roots and rhizomes in growth position. In size and growth habit they resemble Carex, the dominant genus of emergent vascular plants low in fresh and brackish tidal marshes of Grays Harbor. The peaty mud also contains microfossil assemblages consistent with fresh and brackish salinities, as discussed below.

The thick unit of peaty mud terminates upward at a contact that is typically abrupt, and which is neither horizontal nor burrowed. The change in sediment type across this upper contact is abrupt in all the conserved cores except A5 (fig. 14). The contact is about $2 \mathrm{~m}$ higher on average in the Aberdeen boreholes than in the Hoquiam boreholes; its approximate depth range, relative to mean sea level, is 25.5$27.5 \mathrm{~m}$ in Aberdeen and 27.5-29.0 $\mathrm{m}$ in Hoquiam (figs. 2 and 14). We noticed no burrows that extend from the contact downward into the underlying peaty mud.

\section{Higher, Thinner Bodies of Peaty Mud}

Additional peaty mud is present higher in the section in three of the Aberdeen cores. A localized body of peaty mud extends nearly $3 \mathrm{~m}$ upward from a depth of $25 \mathrm{~m}$ in core A1. A more widespread unit 1.0-1.5 m thick was encountered about $10 \mathrm{~m}$ below present sea level in A1, A2, and A3. It is bounded above by a nearly horizontal unconformity that is overlain by sand and gravel and which probably coincides with a hiatus of several thousand years (fig. 2).

\section{Open-Bay Deposits}

Sand and mud, probably deposited on tidal flats and in tidal channels, make up most of the section in every borehole. The deposits range from laminated to structureless. Locally the unit contains gravel lenses, light brown mud clasts 1-2 $\mathrm{cm}$ in diameter, and sand-filled cracks that taper downward in soft mud. Most of the sand is very fine grained.

This thick unit of sand and mud contains estuarine bivalves throughout most of its vertical extent. The most common of these molluscan fossils are a thin-shelled Macoma about $1 \mathrm{~cm}$ long, perhaps $M$. inquinata, typically as fragments. Also noted were remains of the blue mussel Mytilus edulus, the mud clam Mya arenaria, and barnacles (Balanus).

Diatom analysis of the lowest part of the sand and mud, immediately above the peaty mud at $25-30 \mathrm{~m}$ below present sea level, showed the presence of low-salinity taxa discussed below. 
Hoquiam (fig. 1E)

Aberdeen (fig. 1F)

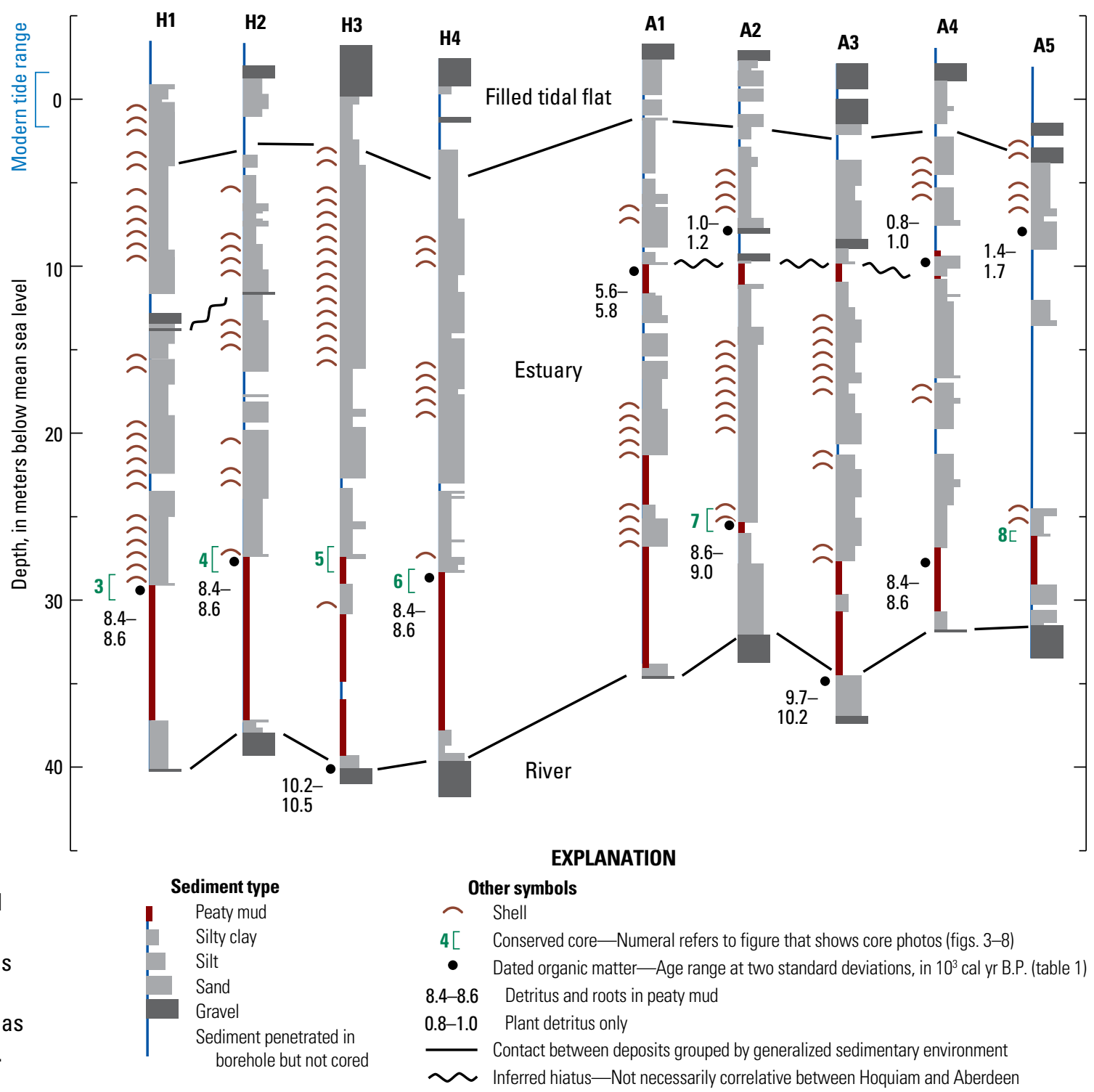

Table 1. Radiocarbon ages from dry-dock cores at Grays Harbor.

[Ages measured by Beta Analytic (Beta) and by National Ocean Sciences Accelerator Mass Spectrometry (NOSAMS)]

\begin{tabular}{|c|c|c|c|c|c|c|}
\hline Core & Lab no. & $\begin{array}{l}\text { Depth }(\mathrm{m}) \text { below } \\
\text { top of core }\end{array}$ & $\begin{array}{l}\text { Depth (m) below } \\
\text { mean sea level') }\end{array}$ & Material dated & Age $\left({ }^{14} \mathrm{C}\right.$ yr B.P. $)$ & Age (cal yr B.P.) \\
\hline A5 & Beta-263,295 & 9.69 & 8.0 & Plant detritus? & $1,660 \pm 40$ & $1,693-1,418$ \\
\hline A1 & Beta-263,290 & 13.17 & 10.0 & Peaty mud & $4,950 \pm 40$ & $5,842-5,597$ \\
\hline $\mathrm{A} 2$ & NOSAMS-88,068 & 28.39 & 25.9 & Peaty mud & $7,960 \pm 45$ & $8,991-8,648$ \\
\hline A4 & Beta-263,294 & 30.75 & 27.9 & Peaty mud & $7,710 \pm 50$ & $8,586-8,413$ \\
\hline $\mathrm{H} 4$ & Beta-263,300 & 30.72 & 28.5 & Peaty mud & $7,690 \pm 50$ & $8,581-8,401$ \\
\hline H1 & Beta-263,296 & 32.92 & 29.6 & Peaty mud & $7,780 \pm 50$ & $8,641-8,428$ \\
\hline A3 & Beta-263,292 & 39.32 & 37.4 & Plant detritus? & $8,860 \pm 50$ & $10,172-9,743$ \\
\hline $\mathrm{H} 3$ & Beta-263,299 & 43.47 & 40.5 & Plant detritus? & $9,150 \pm 50$ & $10,172-9,743$ \\
\hline
\end{tabular}

${ }^{1}$ Tops of borings were surveyed to mean lower low water, a tidal datum $1.7 \mathrm{~m}$ below mean sea level at Aberdeen ("Methods," p. 7).

${ }^{2}$ Range at two standard deviations. Conversion from ${ }^{14} \mathrm{C}$ yr B.P. to cal yr B.P. explained under "Methods." 


\section{Details in the Conserved Cores}

The core sections depicted in figures 3-8 span the top of the thick peaty mud in Hoqiuam borings $\mathrm{H} 1-\mathrm{H} 4$ and in Aberdeen borings A2 and A5. The locations of these core sections are marked with green brackets in figure 2 . The graphs in figures 9 and 10 summarize diatom assemblages in the conserved core sections from borings $\mathrm{H} 2, \mathrm{H} 4$, and A5. Photomicrographs in figures 11-13 illustrate diatom key taxa in $\mathrm{H} 1-\mathrm{H} 4$ and A5. Annotated diagrams in figure 14 offer ecological interpretations of the conserved cores from borings $\mathrm{H} 2, \mathrm{H} 4, \mathrm{~A} 2$, and $\mathrm{A} 5$.

\section{Physical Stratigraphy Across the Top of the Peaty Mud}

The thick peaty mud terminates abruptly at its upper contact in all four of the Hoquiam borings. It is overlain by sand in each case. In H1 the sand is probably anomalously thick and coarse relative to the bay deposits in the overlying $1 \mathrm{~m}$ or more. The sand does not stand out in this way, however, in the conserved core section from boring $\mathrm{H} 2$ (lithologic sketch in fig. 14) nor in the full log of boring H4 (fig. 2).

The sequence across the top of the peaty mud differs further between the two conserved core sections from Aberdeen. In A2 the top of the peaty mud is abrupt but lacks an anomalous basal layer of sand (sketch, fig. 14). In A5 the highest peaty mud does not appear to terminate abruptly, because it is capped by a few centimeters of sandy peaty mud, and because, as discussed below, this deposit contains a diatom assemblage intermediate between the assemblages that bracket it.

\section{Paleoecology Inferred from Microscopic Fossils}

Low-salinity diatom assemblages are present both above and below this variable upper contact of the peaty mud (fig. 9). The assemblages consistently differ across the contact in proportion of brackish and planktonic taxa while varying among the cores in detail. These findings are based on counts for select samples from conserved segments of cores A5, H2,
Figure 3. Photographs of conserved core from boring $\mathrm{H} 1$, showing upward change from peaty mud to an overlying unit of mud and sand. 


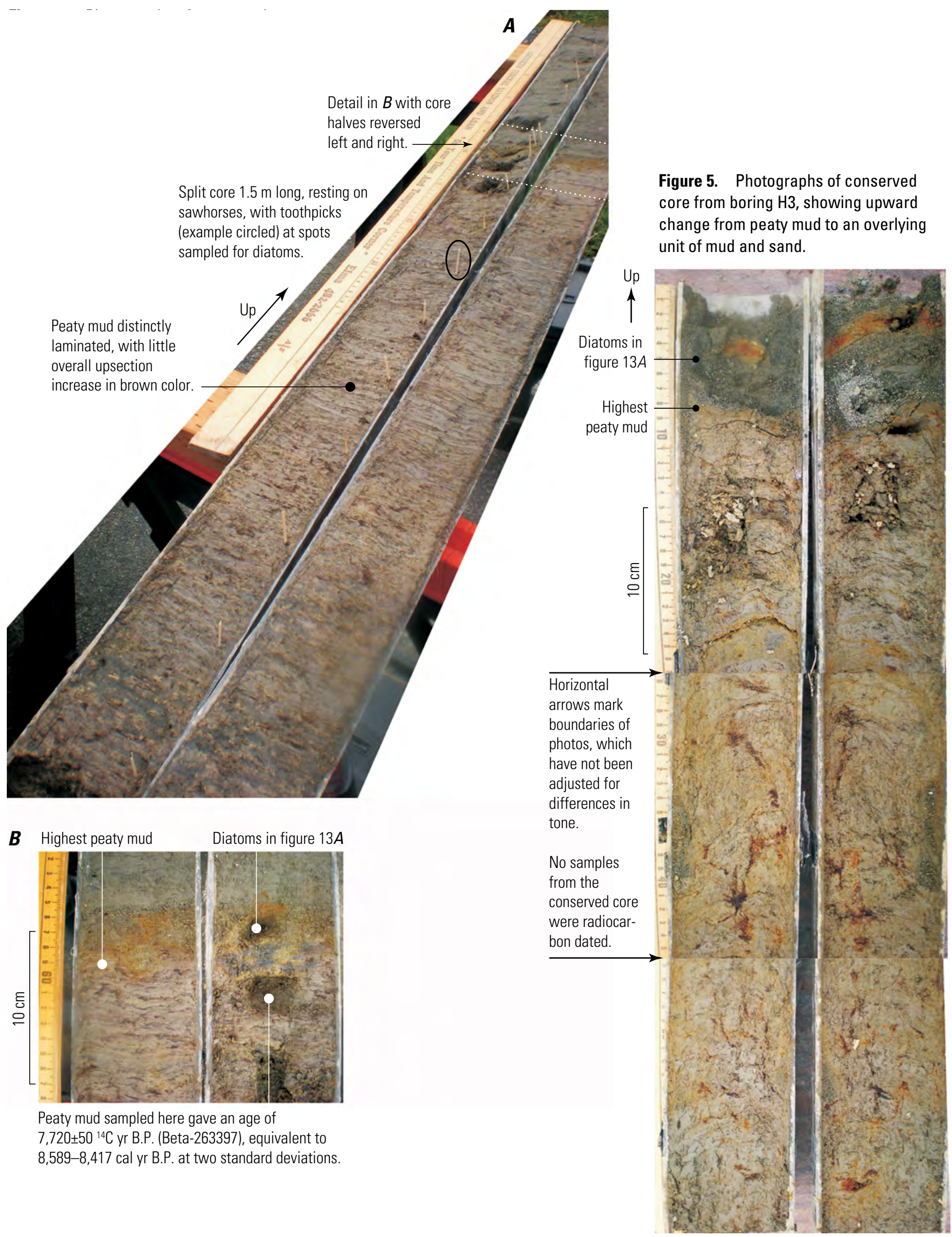


and $\mathrm{H} 4$ (table 2; figs. 9-12), and on qualitative observations of a number of additional samples from those three cores and from cores A2, H1, and $\mathrm{H} 3$ (figs. 4, 6, 7, 13, and 14).

Overall, the diatom assemblages represent lower salinities than do the microfossils usually considered in studies of abrupt coastal subsidence in Cascadia. Those studies make use of brackish and marine taxa found both as fossil valves and as frustules in modern marshes (Nelson and Kashima, 1993; Hemphill-Haley, 1995; Nelson and others, 1996; Shennan and others, 1996; Atwater and Hemphill-Haley, 1997; Shennan and others, 1998; Hawkes and others, 2011; Wang and others, 2013). The early Holocene salinities inferred below are also exceeded by those of modern tidal waters near Aberdeen, where Thom (1984) obtained salinities as high as 10 parts per thousand (ppt).

\section{Diatom Assemblages in the Peaty Mud}

The uppermost meter or less of the peaty mud contains diatom assemblages dominated by Luticola mutica, Pinnularia lagerstedtii, Tryblionella debilis, and several other taxa that are consistent with accumulation in aerated, fresh to slightly brackish marsh environments (fig. 10). The dominant taxa belong to the "oligohalobous indifferent" or "oligohalobous halophilous" halobian categories of Hustedt (1957), meaning that they are commonly found in fresh water ( $0 \mathrm{ppt})$, but also either tolerate or prefer brackish water. Low salinities for the peaty mud are further suggested by the complete absence of foraminifera. Modern analogs may include parts of present-day Seymour-Belize estuary in British Columbia, where sustained salinities under 3 ppt support assemblages

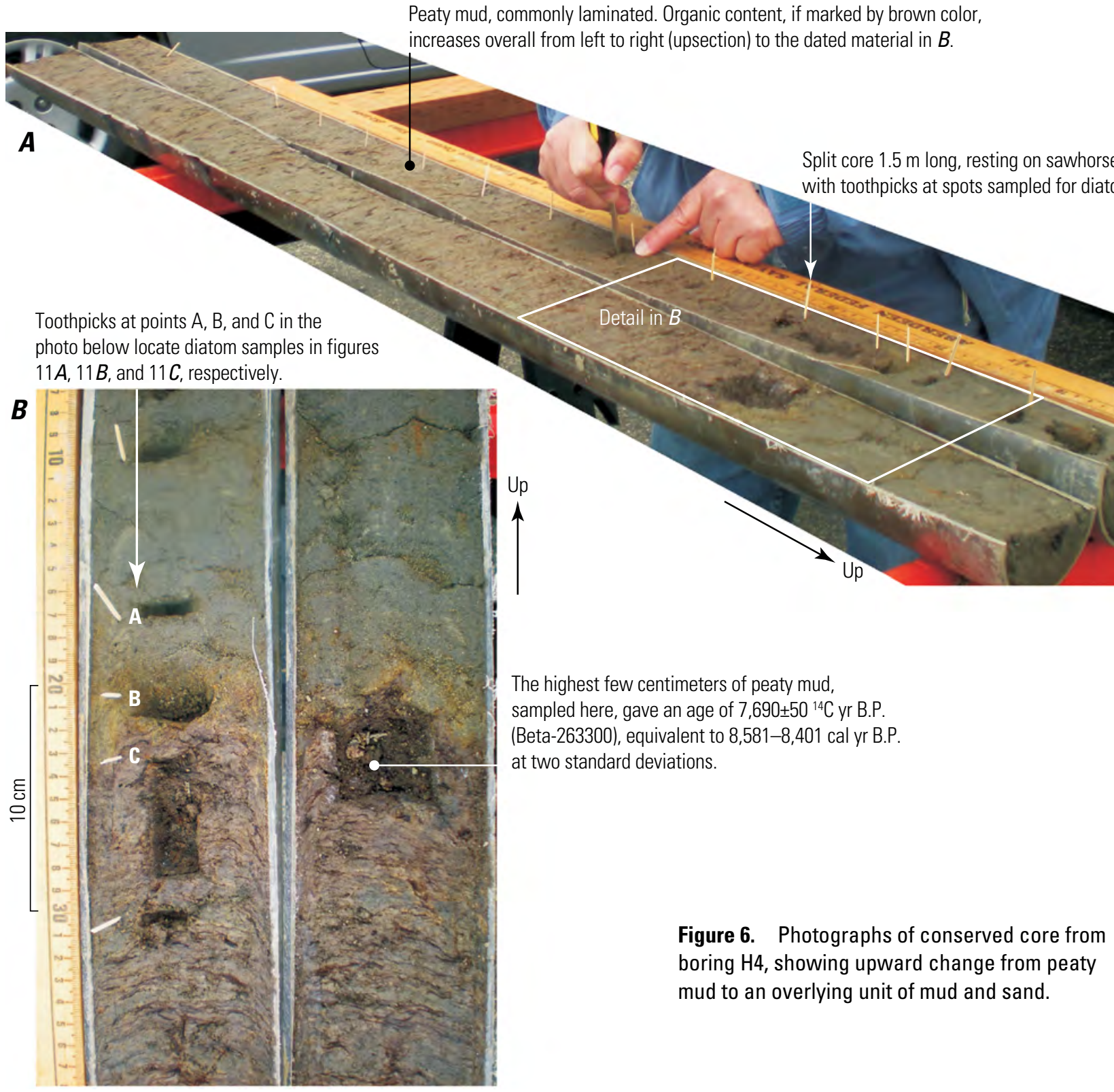


Figure 7. Photographs of conserved core from boring $A 2$, showing upward change from peaty mud to an overlying unit of mud and sand.

A

(
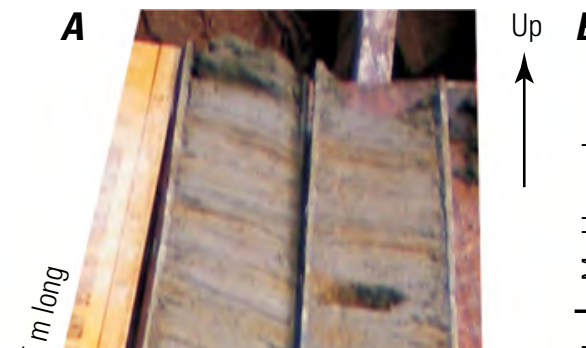

$\boldsymbol{B}$

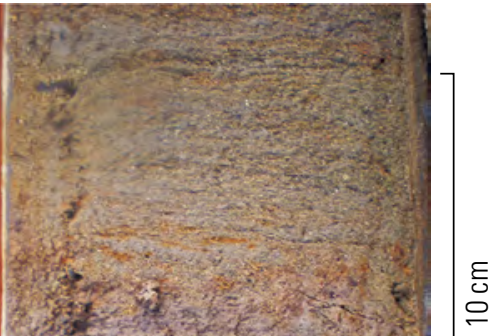

등 
of olioghalobous diatoms (Roe and others, 2009) but not foraminifera (Riveiros and others, 2007).

Diatom assemblages high in the peaty mud are similar among A5, H2, and H4 in overall abundance (fig. 9) and in stratigraphic variability (fig. 10). High diatom concentrations in the peaty mud of $\mathrm{H} 2$ and $\mathrm{H} 4$ coincide with visual evidence for elevated organic content- the presence of brown color and decomposed plant remains.

\section{Diatom Assemblages Across the Top of the Peaty Mud}

The contact at the top of the peaty mud coincides with a boundary in diatom abundance (table 2; fig. 9). In $\mathrm{H} 4$ the diatom concentration is two orders of magnitude greater in the highest peaty mud than in the overlying silty mud. The peaty mud probably represents a marsh that supported prolific benthic taxa, while the overlying mud suggests an environment poorly suited for benthic diatom growth (figs. 9, 10).

Diatom abundance changes less abruptly across the top of the peaty mud in the conserved cores from borings $\mathrm{H} 2$ and A5 (fig. 9). In these deposits, diatom concentration decreases upward in the highest peaty mud (H2) or through the sandy peaty mud that may be a transitional deposit (A5). The sandy peaty mud contains planktonic diatoms as well as benthic taxa (Tryblionella spp., Surirella brebissonii, Diploneis smithii var. rhombica) that are prominent in the overlying clayey silt (figs. 9, $10,12,14)$. The assemblage is intermediate between those of the peaty mud below (abundant small taxa typical of marshes) and

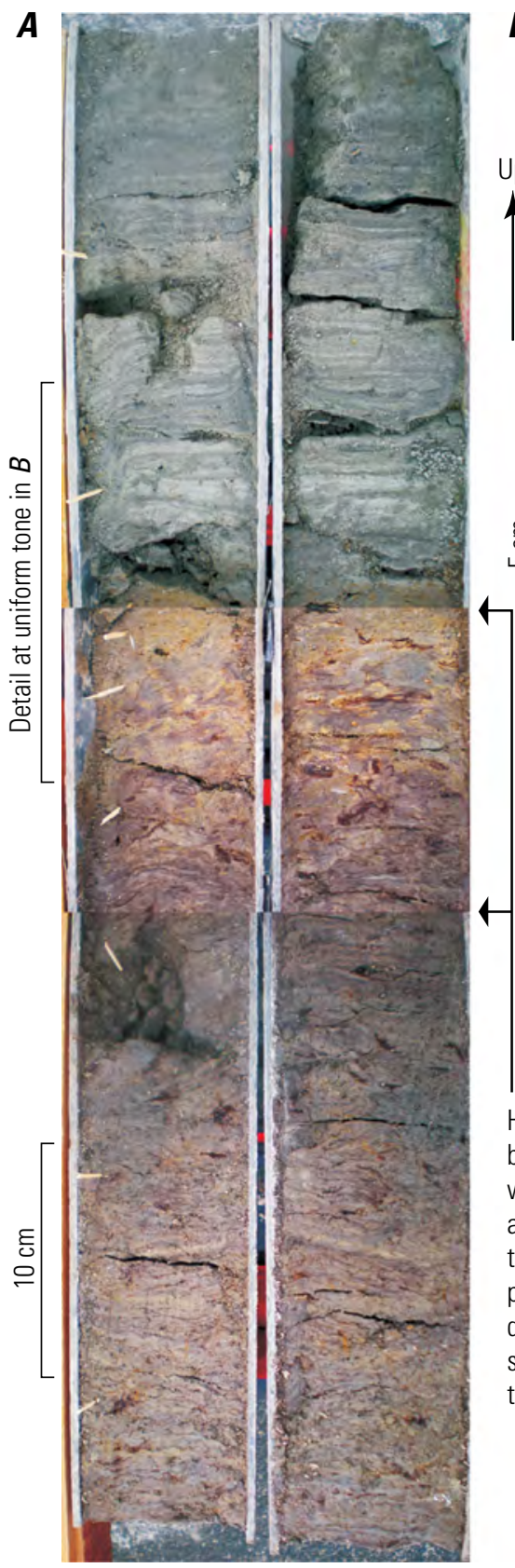

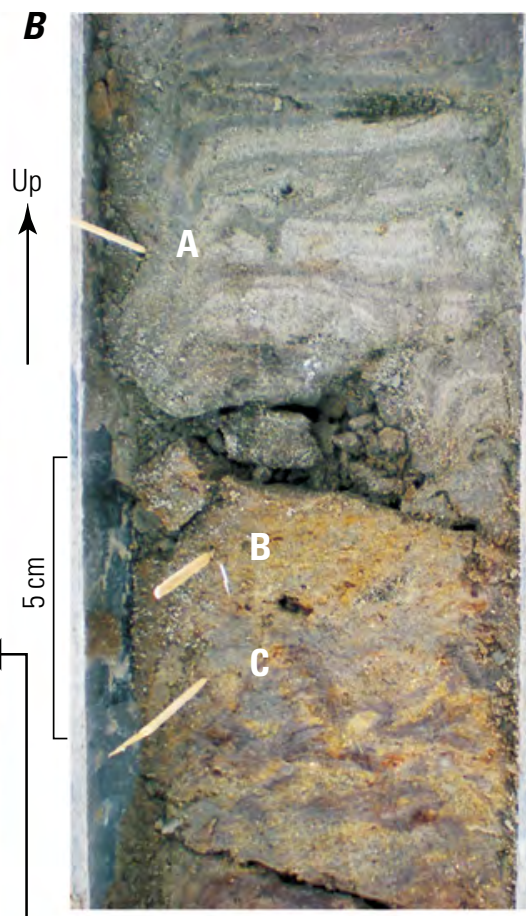

Toothpicks at $A, B$, and $C$ in the photo above locate diatom samples in figure $12 A, 12 B$, and $12 C$, respectively

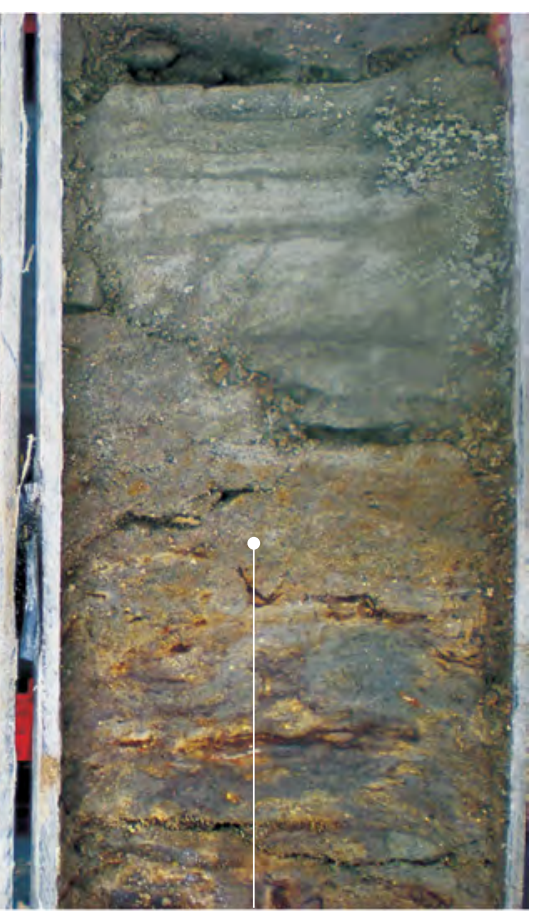

Highest peaty mud
Horizontal arrows mark boundaries of photos, which have not been adjusted for differences in tone. Toothpicks mark places sampled for diatoms. No radiocarbon samples were dated from the conserved core.
Figure 8. Photographs of conserved core from boring $A 5$, showing upward change from peaty mud to an overlying unit of mud and sand. 

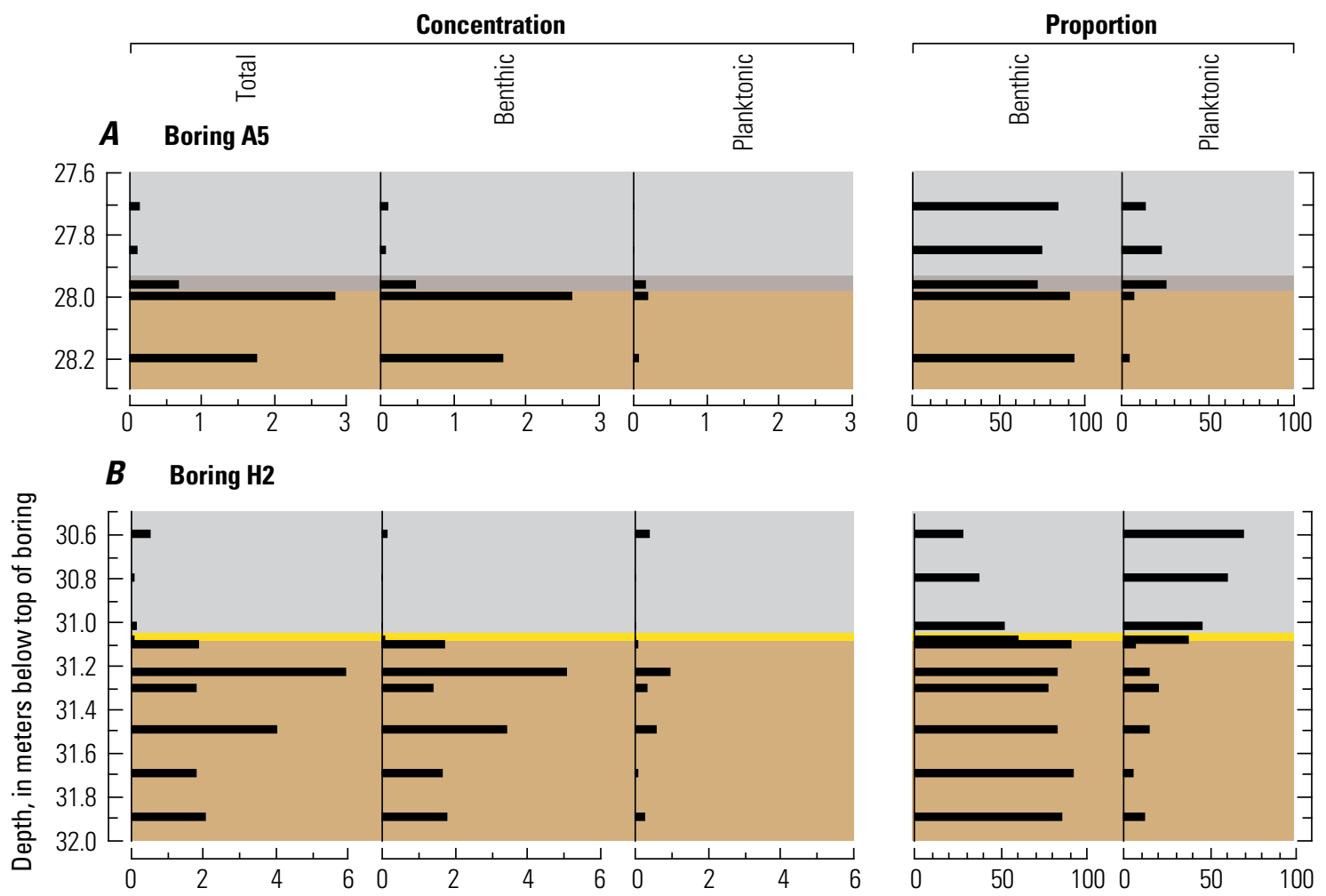

\section{Boring $\mathrm{H4}$}

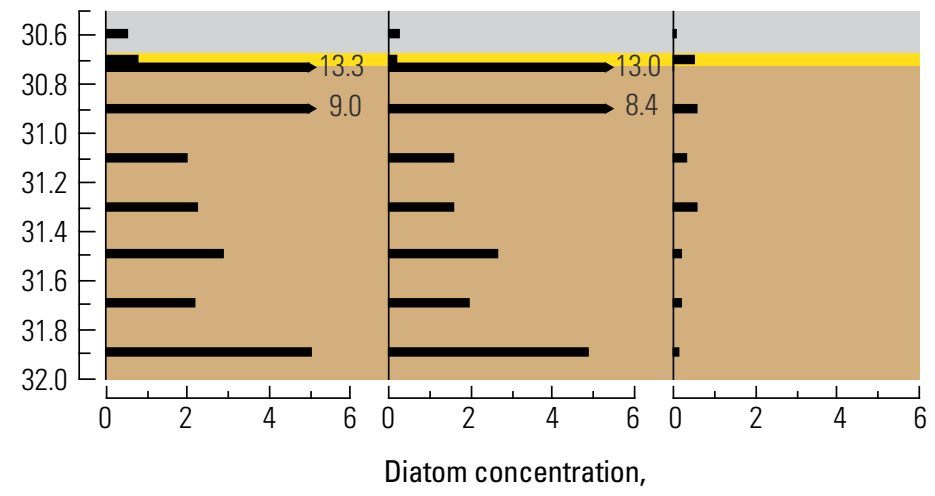

in millions of valves per cubic centimeter of sediment

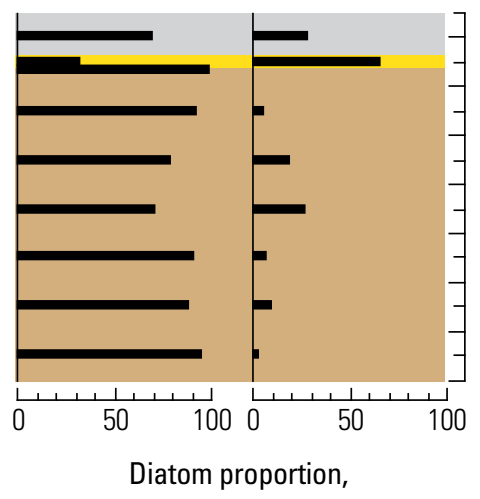

in percentage of all valves counted

\section{EXPLANATION}

Figure 9. Graphs of diatom concentrations (in estimated valves per cubic centimeter of sediment) and relative percentage of benthic and planktonic taxa in samples from borings $\mathrm{A} 5, \mathrm{H} 2$, and $\mathrm{H} 4$.
[Diatoms analyzed from conserved core sections illustrated in figures $4(\mathrm{H} 2), 6(\mathrm{H} 4)$, and $8(\mathrm{~A} 5)$. Additional details in table 2]

Mud and sand-Chiefly clayey silt

Sandy peaty mud-Apparently transitional between deposits above and below

Silty sand-Additional sand noted above in H2 (diagrammatic in detailed sketch, fig. 14) and $\mathrm{H} 4$ (generalized log of entire boring, fig. 2)

Peaty mud 

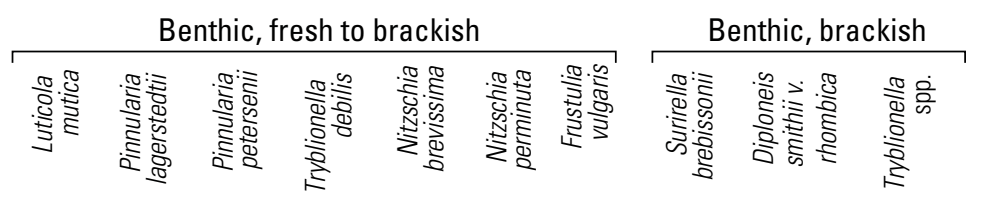

\section{A Boring A5}
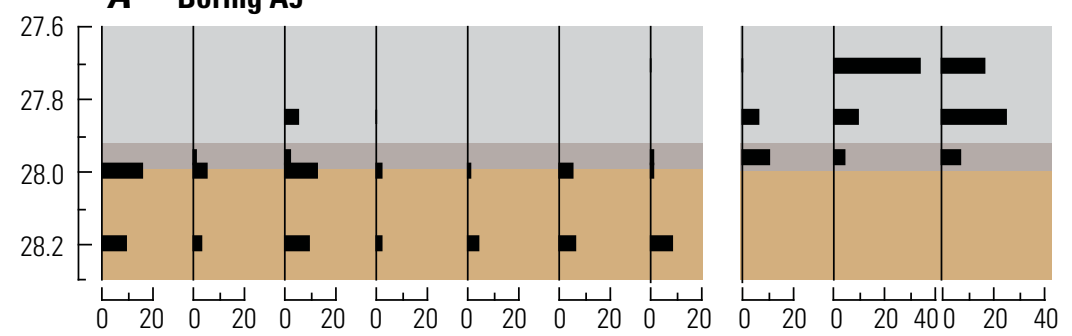
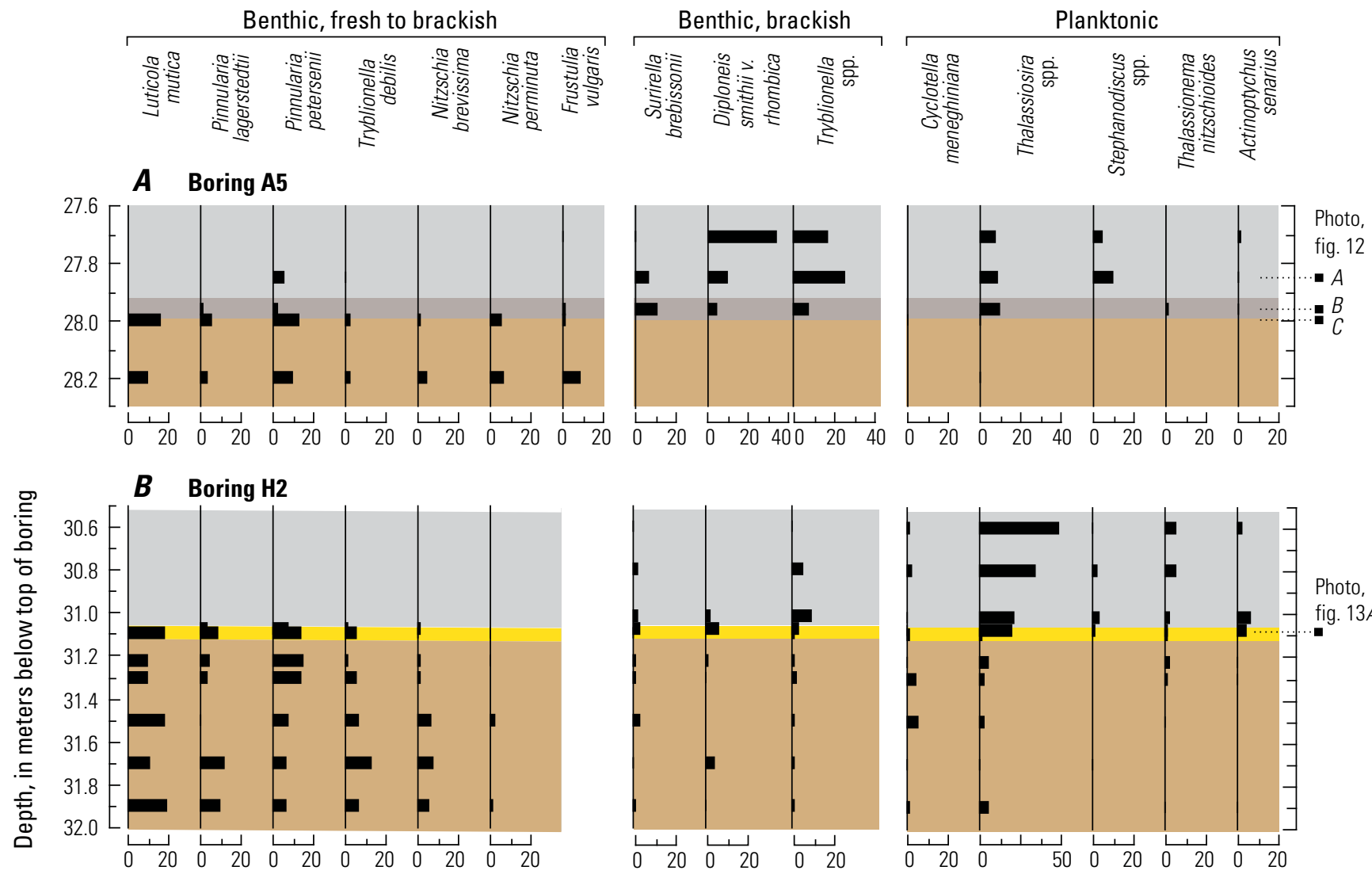

\section{Boring $\mathrm{H4}$}

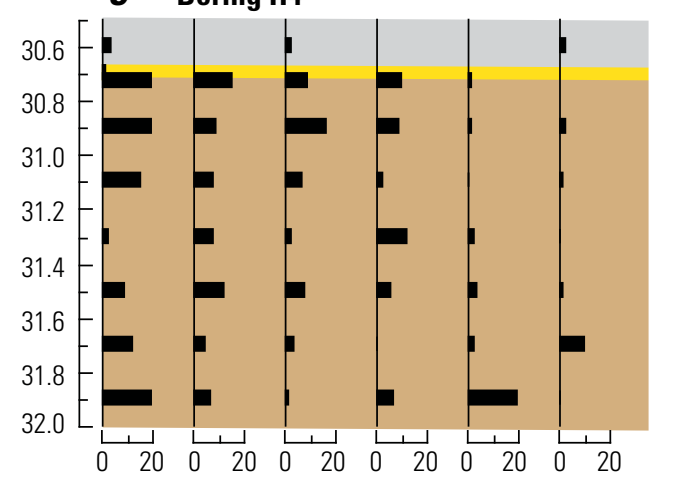

Diatom proportion, in percentage of all valves counted
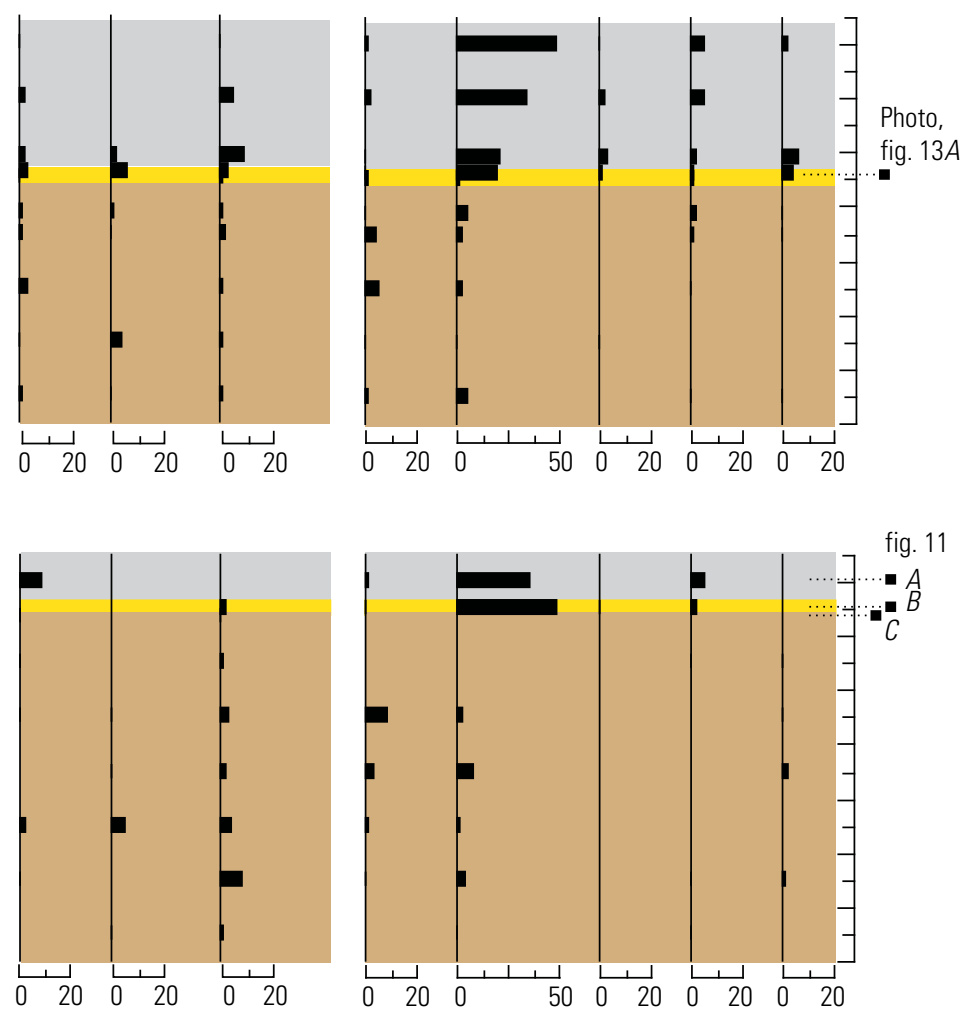

fig. 11

\section{EXPLANATION}

Figure 10. Graphs showing proportions of diatom taxa that make up more than 5 percent of at least one sample across the top of the thick peaty mud in borings $\mathrm{A} 5, \mathrm{H} 2$, and H4. The benthic group termed fresh to brackish includes taxa commonly found in marsh environments that have low salinity and are exposed to air. The brackish benthic group includes taxa that proliferate in muddy environments and tolerate salinity typically as high as 10 parts per thousand (ppt). The planktonic group includes taxa that span a wide range of salinities and are commonly found in estuaries.
[Diatoms analyzed from conserved core sections illustrated in figures 4 (H2), 6 (H4), and 8 (A5). Additional details in table 2]

Mud and sand — Chiefly clayey silt

Sandy peaty mud - Apparently transitional between deposits above and below

Silty sand —-Additional sand noted above in $\mathrm{H} 2$ (diagrammatic in detailed sketch, fig. 14) and $\mathrm{H} 4$ (generalized log of entire boring, fig. 2)

Peaty mud 
Figure 11. Photomicrographs showing diatoms from above and below the top of the peaty mud in boring $\mathrm{H} 4$. (A) Benthic diatoms above the contact are rare and poorly preserved. They include the broken valves of Tryblionella sp. (1) and Surirella brebissonii (2). The assemblage may represent reworking in a subtidal setting. (B) Silty sand immediately above the peaty mud unit contains wellpreserved planktonic diatoms of Thalassiosira spp. $(3,4)$ and broken valves of benthic taxa that include S. brebissonii (5). (C) A sample high in the peaty mud abounds in small, well-preserved valves of the benthic diatoms Pinnularia sp. (6) and Luticola mutica $(7,8)$, along with rare planktonic diatoms and larger brackish benthic taxa such as Tryblionella sp. (9).

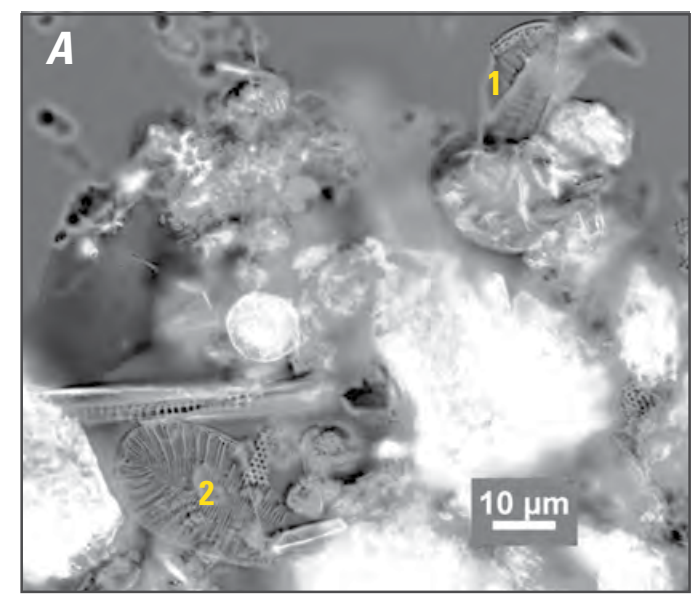

Boring $\mathrm{H} 4,30.60 \mathrm{~m}$, clayey silt

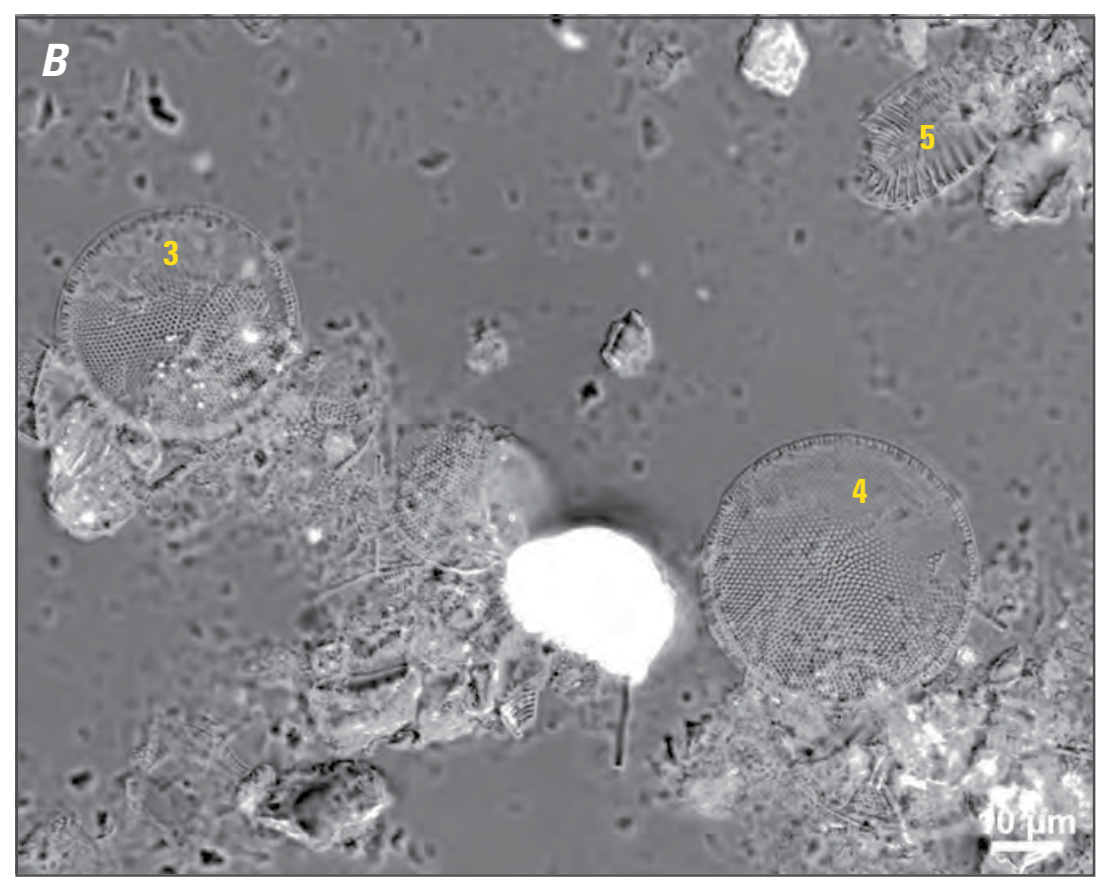

Boring $\mathrm{H} 4,30.70 \mathrm{~m}$, silty sand immediately above peaty mud.

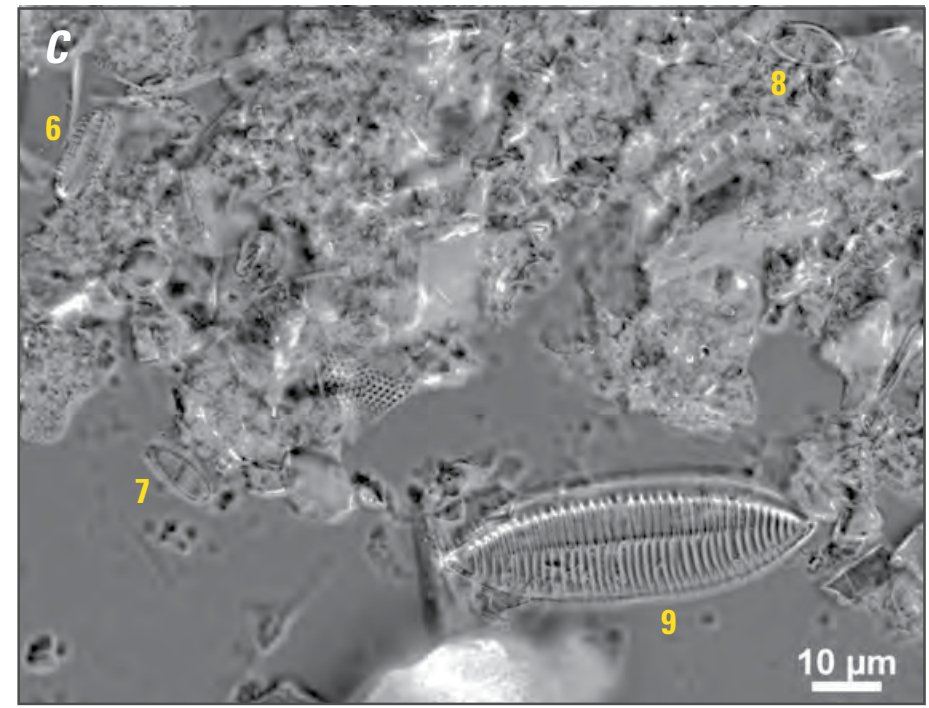

Boring $\mathrm{H} 4,30.73 \mathrm{~m}$, peaty mud 
Figure 12. Photomicrographs showing diatoms from above and below the top of the peaty mud in boring $A 5$. (A) Diatoms in clayey silt above the top contact are rare. They include wellpreserved specimens of Tryblionella spp. (1), Surirella brebissonii (2), and small planktonic diatoms (3). (B) Diatoms are also rare in sandy peaty mud interpreted as transitional between the peaty mud and the deposits above it. The assemblage here includes wellpreserved planktonic diatoms (4) along with large benthic taxa that also found in the overlying clayey silt: Tryblionella spp. (5) and Diploneis smithii var. rhombica (6). (C) Diatoms in the peaty mud are abundant and consist of benthic, fresh-brackish taxa such as Pinnularia lagerstedtii (7), Frustulia vulgaris (8), and P. pertersenii.

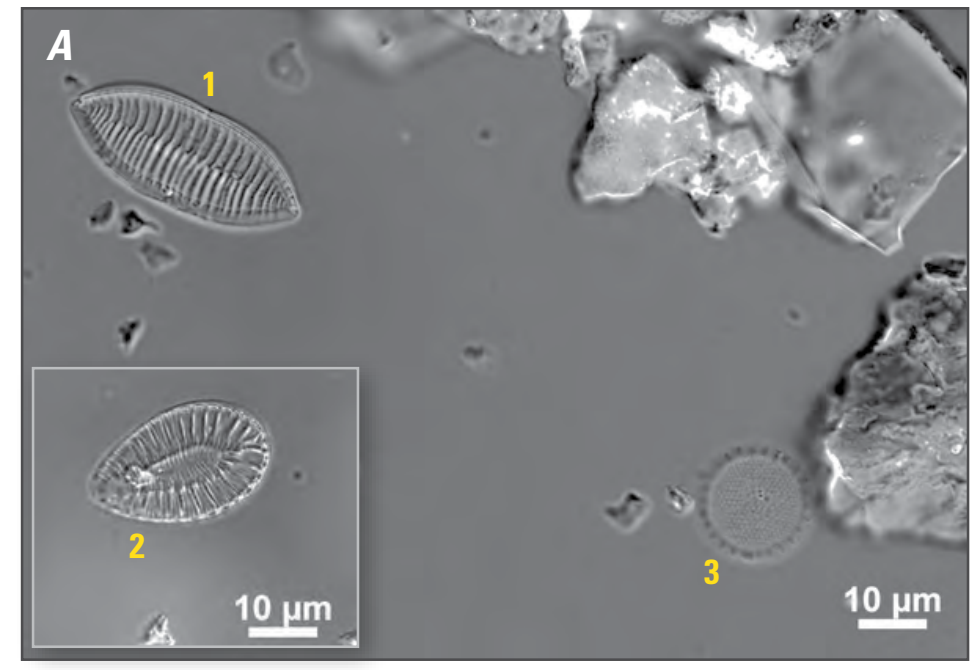

Boring A5, 27.85 m, clayey silt

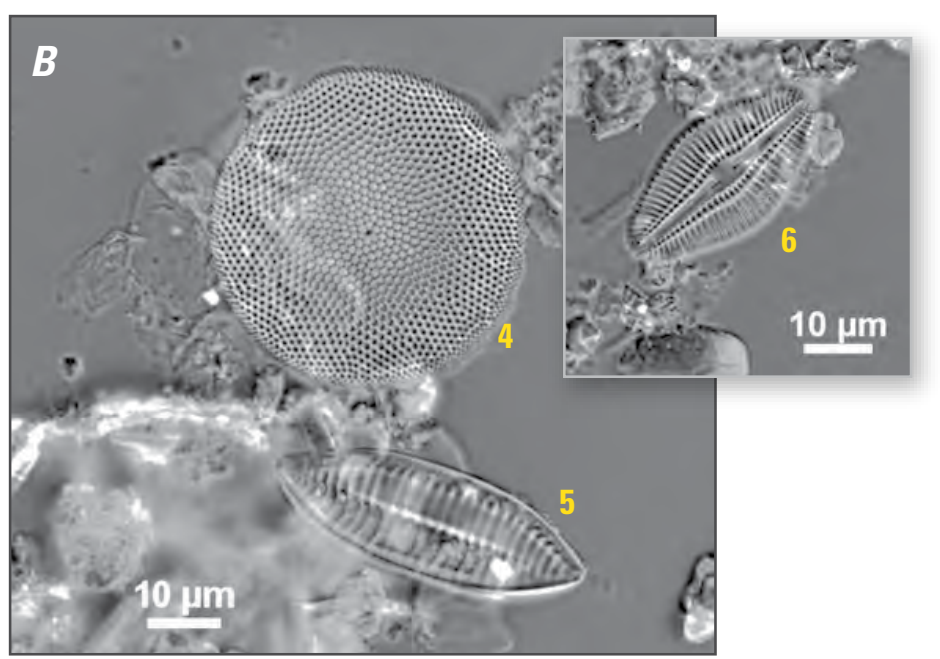

Boring A5, $27.96 \mathrm{~m}$, layer apparently transitional between the peaty mud below and the mud and sand above.

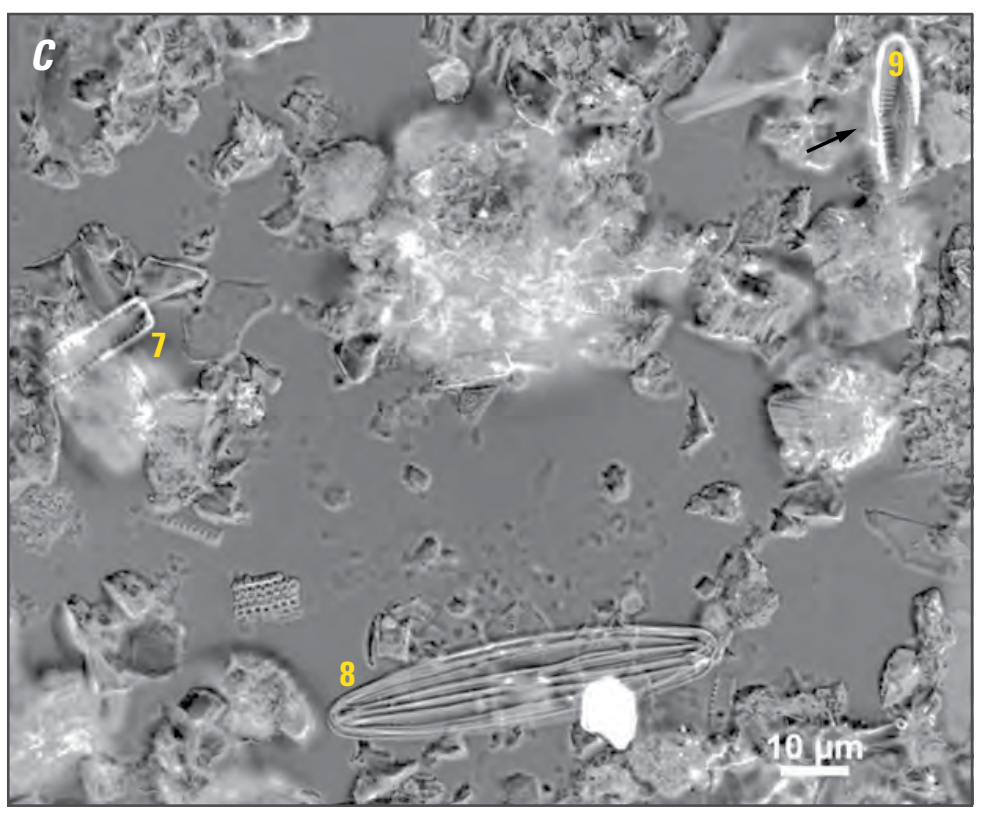

Boring A5, $28.00 \mathrm{~m}$, peaty mud 


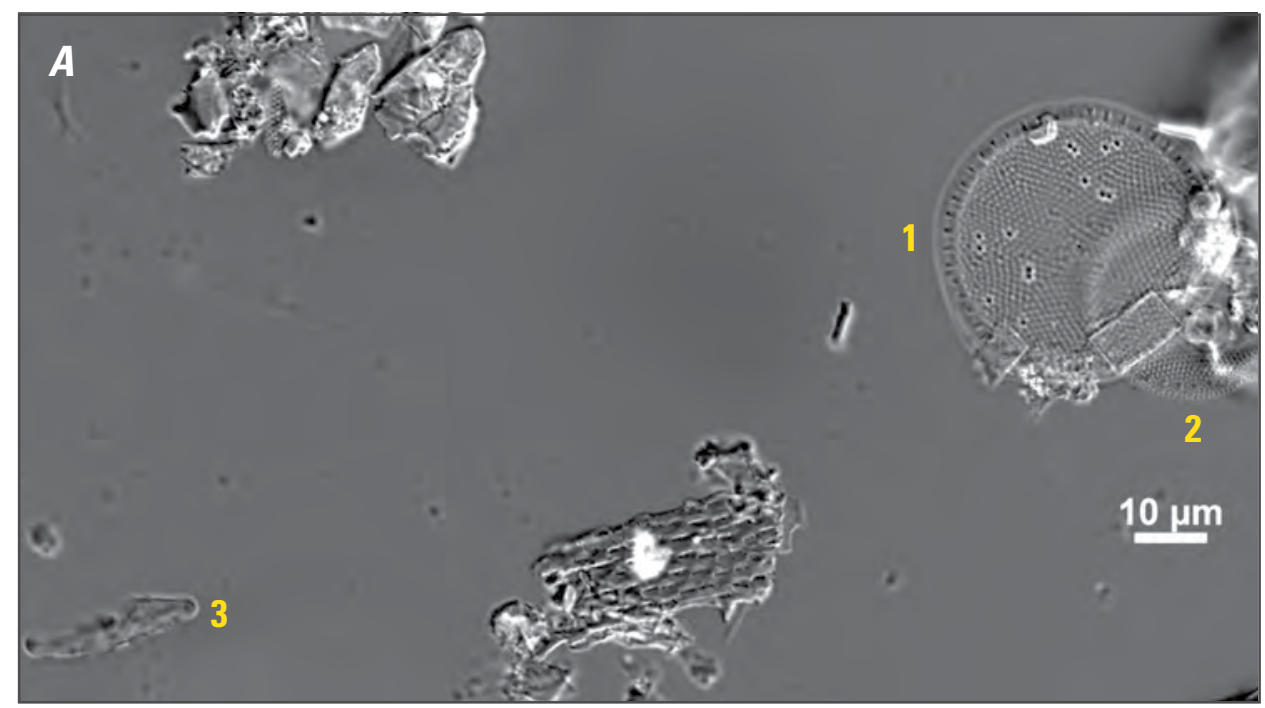

Boring H2, 31.04 m, silty sand

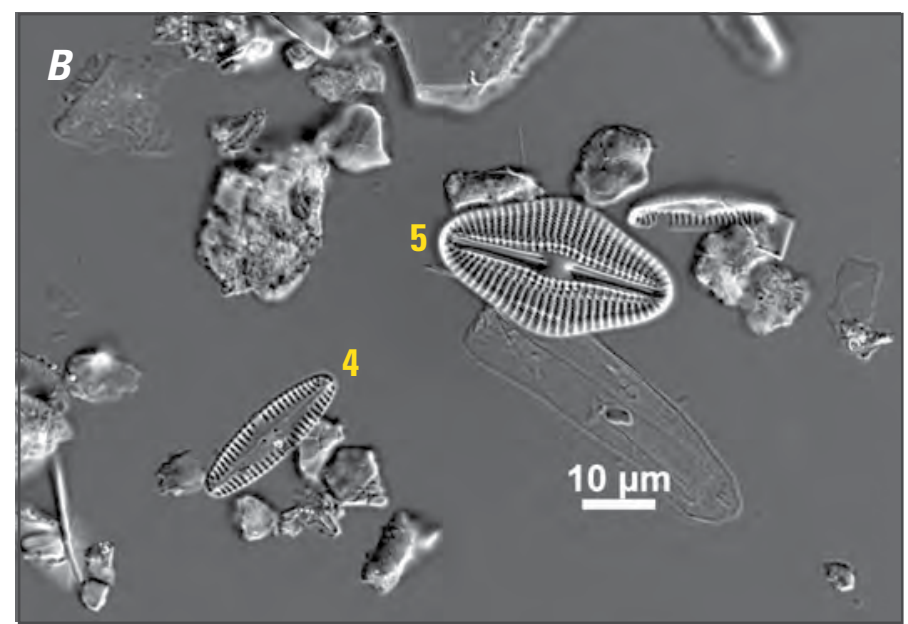

Boring H1, $32.92 \mathrm{~m}$, silty sand

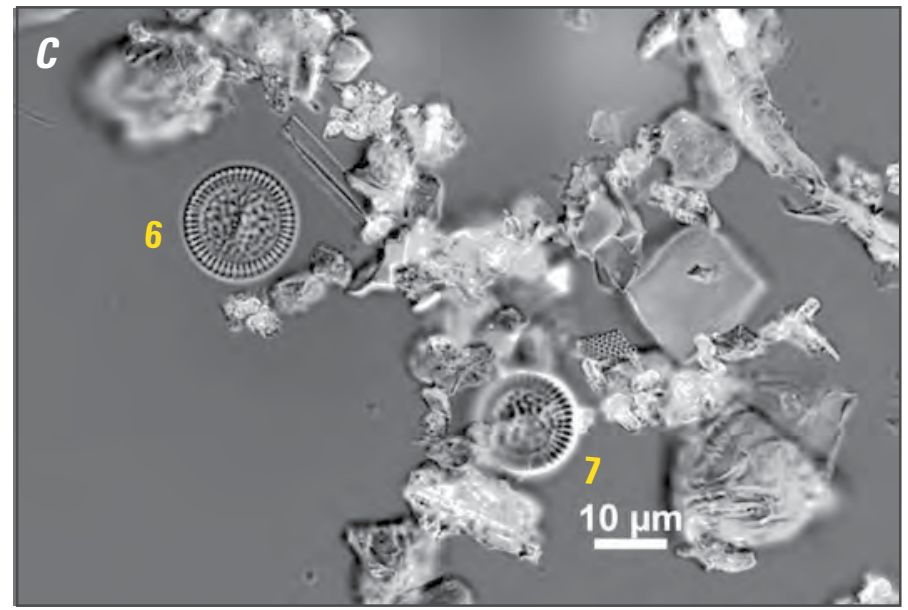

Figure 13. Photomicrographs showing variation among diatom assemblages in silty sand that caps the thick peaty mud in cores $\mathrm{H} 1, \mathrm{H} 2$, and $H 3$. (A) As in the capping layer in $\mathrm{H} 4$ (fig. 12B), the assemblage in the silty sand in $\mathrm{H} 2$ is dominated by planktonic diatoms, including Thalassiosira spp. (1, 2), and by broken benthic diatoms (3). (B) By contrast, wellpreserved benthic diatoms like Pinnularia pertersenii (4) and Diploneis smithii var. rhombica (5) predominate in core $\mathrm{H} 1$, while $(\boldsymbol{C})$ a diverse assemblage in $\mathrm{H} 3$ abounds in the planktonic Cyclotella meneghiniana $(6,7)$.

Boring H3, 30.54 m, silty sand 
Figure 14. (A) Diagram summarizing sediment types and microfossil assemblages, four of the conserved core sections that span the tidal-marsh deposits dated to around $8,500 \mathrm{cal}$ yr B.P. Section locations are shown as green brackets in figure 2. (B) Boring locations plotted on airphotos excerpted from figure 1.

A

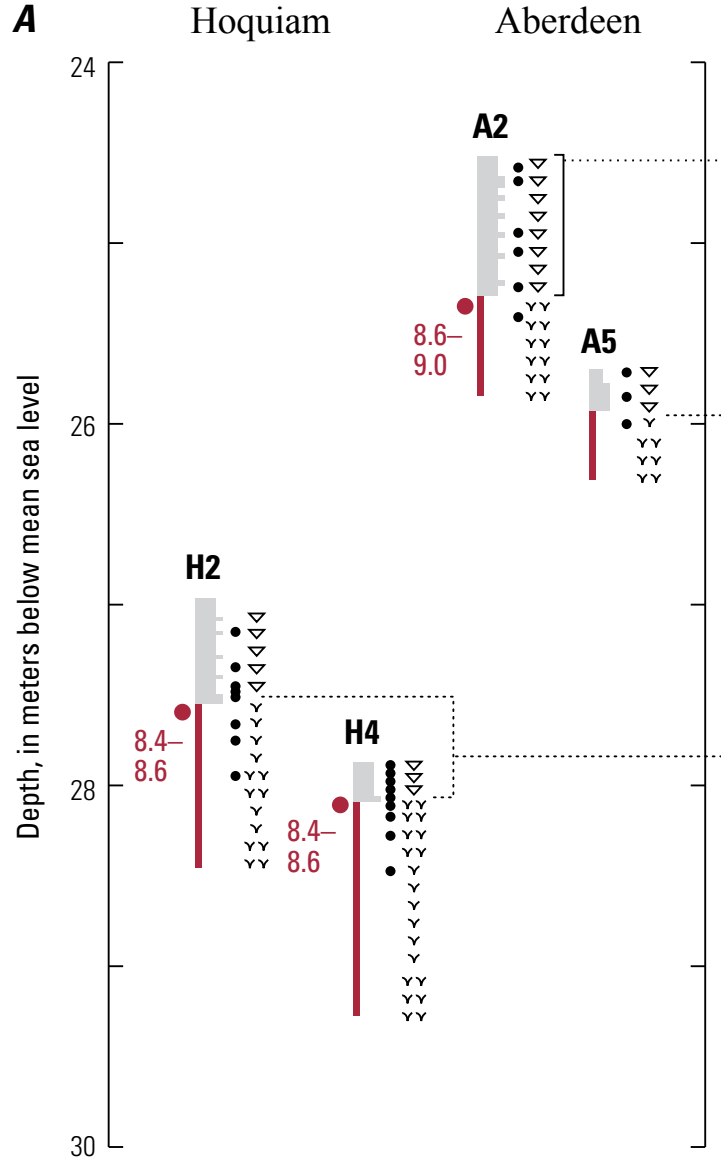

A2-Peaty mud dated to $9,000-8,600$ cal yr B.P. in core $A 2$ is overlain by $75 \mathrm{~cm}$ of mud and sand without a distinct bed of basal sand (fig. 7). Diatoms in this mud-and-sand interval are rare overall and are dominated by large, brackish benthic taxa and small planktonic taxa

A5-The highest peaty mud here in boring $\mathrm{A} 5$ is sandy, and its diatom assemblage is transitional between the assemblages below and above it in diatom abundance (fig. 9A). It is also transitional in containing a mix of small valves of benthic taxa typical of fresh and brackish marshes, large valves of brackish taxa, and estuarine planktonic diatoms (fig. 10A)

H2, H4 - Fine sand rests on peaty mud dated to $8,600-8,400$ cal yr B.P. in borings $\mathrm{H} 2$ and $\mathrm{H} 4$, but sand is also common higher in the conserved core from $\mathrm{H} 2$ (sketch at left). Diatoms in the basal sand are very rare (fig. $9 B, C$ ). They include several planktonic species (fig. 10B,C) without implying higher salinity than do diatoms in the other samples plotted in this figure. The peaty mud below the sand in $\mathrm{H} 4$ probably represents a higher position in the intertidal zone than does the peaty mud below the sand in $\mathrm{H} 2$.

\section{EXPLANATION}

- Dated sample of peaty

$8.4-$

8.6
mud-Age range in $10^{3}$ cal yr B.P.

\section{Sediment type}

Peaty mud

Silty clay

Silt

Sand
Depositional environment inferred from diatoms

Tidal marsh

$\checkmark v$ High-Peaty; diatoms common

$\checkmark \quad$ Low-Silty; diatoms rare

$\nabla$ Unvegetated tidal flat or channel

- Low salinity inferred from absence of foraminifera
B

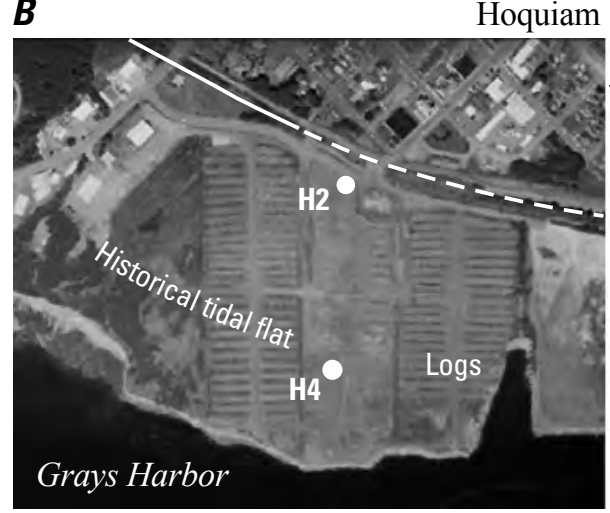

Aberdeen
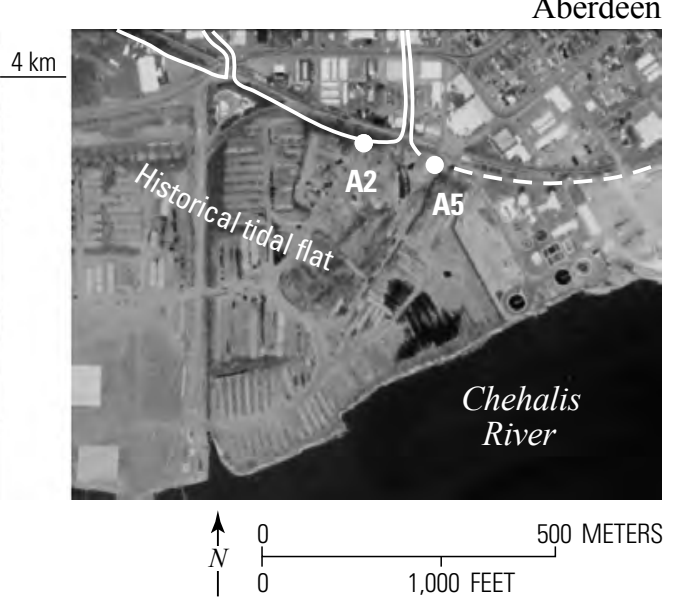
Table 2. Diatom data from Grays Harbor boreholes A5 (Aberdeen), and H2, H4 (Hoquiam).

\begin{tabular}{|c|c|c|c|c|c|c|c|}
\hline Core & $\begin{array}{c}\text { Depth } \\
\text { (m below } \\
\text { top of } \\
\text { core) }\end{array}$ & Lithology & $\begin{array}{c}\text { Total } \\
\text { valves } \\
\text { counted }\end{array}$ & $\begin{array}{c}\text { Area of } \\
\text { slide } \\
\text { examined } \\
\left(\mathrm{mm}^{2}\right)\end{array}$ & $\begin{array}{c}\text { Diatom } \\
\text { concentration } \\
\text { (estimated } \\
\text { valves per } \mathbf{c m}^{3} \\
\text { of sediment) } \\
\end{array}$ & $\begin{array}{l}\text { Percent } \\
\text { benthic } \\
\text { diatoms }\end{array}$ & $\begin{array}{c}\text { Percent } \\
\text { planktonic } \\
\text { diatoms }\end{array}$ \\
\hline A5 & 27.71 & Mud & 121 & 110 & $1.5 \mathrm{E}+05$ & 86.0 & 14.0 \\
\hline A5 & 27.85 & Mud & 100 & 99 & $1.3 \mathrm{E}+05$ & 76.0 & 24.0 \\
\hline A5 & 27.96 & Sandy peaty mud & 117 & 22 & $7.0 \mathrm{E}+05$ & 73.5 & 26.5 \\
\hline A5 & 28.00 & Peaty mud & 348 & 16 & $2.9 \mathrm{E}+06$ & 92.5 & 7.5 \\
\hline A5 & 28.20 & Peaty mud & 149 & 11 & $1.8 \mathrm{E}+06$ & 95.3 & 4.7 \\
\hline $\mathrm{H} 2$ & 30.60 & Mud & 100 & 22 & $6.0 \mathrm{E}+05$ & 29.0 & 71.0 \\
\hline $\mathrm{H} 2$ & 30.80 & Mud & 102 & 99 & $1.4 \mathrm{E}+05$ & 38.2 & 61.8 \\
\hline $\mathrm{H} 2$ & 31.02 & Mud & 110 & 88 & $1.7 \mathrm{E}+05$ & 53.6 & 46.4 \\
\hline $\mathrm{H} 2$ & 31.08 & Silty sand & 108 & 88 & $1.6 \mathrm{E}+05$ & 61.1 & 38.9 \\
\hline $\mathrm{H} 2$ & 31.10 & Peaty mud & 317 & 22 & $1.9 \mathrm{E}+06$ & 92.6 & 7.4 \\
\hline $\mathrm{H} 2$ & 31.23 & Peaty mud & 307 & 7 & $6.1 \mathrm{E}+06$ & 83.7 & 16.3 \\
\hline $\mathrm{H} 2$ & 31.30 & Peaty mud & 312 & 22 & $1.9 \mathrm{E}+06$ & 78.2 & 21.8 \\
\hline $\mathrm{H} 2$ & 31.50 & Peaty mud & 341 & 11 & $4.1 \mathrm{E}+06$ & 84.3 & 15.7 \\
\hline $\mathrm{H} 2$ & 31.70 & Peaty mud & 308 & 22 & $1.8 \mathrm{E}+06$ & 92.9 & 7.1 \\
\hline $\mathrm{H} 2$ & 31.90 & Peaty mud & 353 & 22 & $2.1 \mathrm{E}+06$ & 86.4 & 13.6 \\
\hline H4 & 30.60 & Mud & 189 & 55 & $4.5 \mathrm{E}+05$ & 71.2 & 28.8 \\
\hline $\mathrm{H} 4$ & 30.70 & Silty sand & 143 & 22 & $8.6 \mathrm{E}+05$ & 32.9 & 67.1 \\
\hline $\mathrm{H} 4$ & 30.73 & Peaty mud & 354 & 4 & $1.3 \mathrm{E}+07$ & 99.4 & 0.6 \\
\hline $\mathrm{H} 4$ & 30.90 & Peaty mud & 375 & 6 & $9.0 \mathrm{E}+06$ & 93.1 & 6.9 \\
\hline $\mathrm{H} 4$ & 31.10 & Peaty mud & 340 & 22 & $2.0 \mathrm{E}+06$ & 80.3 & 19.7 \\
\hline H4 & 31.30 & Peaty mud & 193 & 11 & $2.3 \mathrm{E}+06$ & 71.5 & 28.5 \\
\hline H4 & 31.50 & Peaty mud & 247 & 11 & $3.0 \mathrm{E}+06$ & 91.5 & 8.5 \\
\hline $\mathrm{H} 4$ & 31.70 & Peaty mud & 281 & 16 & $2.2 \mathrm{E}+06$ & 89.7 & 10.3 \\
\hline $\mathrm{H} 4$ & 31.90 & Peaty mud & 387 & 10 & $5.1 \mathrm{E}+06$ & 96.1 & 3.9 \\
\hline
\end{tabular}

the silty mud above (larger, less abundant, but well-preserved benthic diatoms that tolerate a wide range of salinities and are especially common in brackish water).

The dominant diatom species immediately above the peaty mud differ among the Hoquiam borings. The dominants are estuarine planktonic taxa in $\mathrm{H} 4$ and $\mathrm{H} 2$ (figs. $11 B, 13 A$ ) and benthic marsh taxa in $\mathrm{H} 1$ (fig. 13B). The dominant in $\mathrm{H} 3$ is Cyclotella meneghiniana (fig. 13C), a planktonic diatom that commonly blooms in the tidal freshwater reaches of estuaries (De Sève, 1993).

\section{Diatom Assemblages Higher in the Overlying Mud and Sand}

The organic-poor sand and mud above the peaty mud probably represent low-salinity flats at lower intertidal or subtidal levels. Estuarine planktonic diatoms (Thalassiosira spp., Stephanodiscus spp., Thalassionema nitzschioides) are prominent in these deposits, but low salinities are evidenced by a lack of fully brackish to marine benthic taxa.

Diatom assemblages imply deeper water conditions for the sand and mud analyzed from the Hoqiuam segments than for sandy peaty mud of similar stratigraphic level at
Aberdeen. In $\mathrm{H} 2$ and $\mathrm{H} 4$, planktonic taxa are typically better preserved and more abundant than are benthic taxa (fig. 11), consistent with subtidal or channel deposits not conducive to benthic diatom growth. By contrast in A2 and A5, the silt and sand contain well-preserved euryhaline-brackish benthic taxa such as Surirella brebissonii, Tryblionella spp., and Diploneis smithii var. rhombica (figs. 10, 12). If these benthic diatoms were not transported into deeper water, they imply deposition in the euphotic zone, which spans the top few meters of the water column in upper reaches of presentday Grays Harbor (Newton and others, 1997).

\section{Absence of Foraminifera Despite Presence of Bivalve Shells}

We found no foraminifera, calcareous or agglutinated, in any of the samples checked from the conserved cores. Those samples were collected from both the peaty mud and from the mud and sand above it (fig. 14).

Calcareous foraminifera are absent in the mud and sand despite the preservation of calcareous bivalve shells in the lowest of these deposits in borings $\mathrm{H} 1, \mathrm{H} 2$, and A2 (fig. 2). This contrast can be explained by low salinity in the 
early Holocene estuary without calling upon dissolution of foraminiferal tests. The salinities inferred above from diatom assemblages are probably low enough to have excluded foraminifera. Low salinities are permitted, moreover, by ambiguities about the sources and ecology of the bivalves.

Most of the bivalve shells probably originated elsewhere, and because most were observed as fragments, not in growth position, and because the mud and sand in the conserved cores may have accumulated in filling channels (p. 23-24). Furthermore, salinities of 10 ppt or less are consistent with the modern ranges of most of the bivalve taxa identified from the mud and sand (between approximately $5 \mathrm{~m}$ and $30 \mathrm{~m}$ below sea level in figure 2):

Among the clams assigned to the genus Macoma: Habitats of Macoma balthica include areas of brackish water (Rudy and Hay Rudy, 1983, p. 174). Macoma nasuta is "adapted to a wide range of conditions" (Rudy and Hay Rudy, 1983 , p. 178) and "tolerates high turbidity and low salinity" (Hetherington and Reid, 2003, p. 626). Macoma inquinata, however, is a fully marine species in Oregon, and though it can be mistaken for Macoma species that are tolerant of lower salinities (Rudy and Hay Rudy, 1983), Phipps identified it carefully.

The clam Mya arenaria "tolerates brackish water and low salinity" (Rudy and Hay Rudy, 1983, p. 182).

Salinities associated with the barnacle Mytilus edulus range from $2.3 \mathrm{ppt}$ to $33.9 \mathrm{ppt}$ (Rudy and Hay Rudy, 1983, p. 164) and extend below 5 ppt (Lockwood, 1976).

Among the barnacles assigned to Balanus, $B$. glandula "can survive in low salinities", and $B$. crenatus, though typically marine, has been found in brackish water at Vancouver Island (Rudy and Hay Rudy, 1983, p. 84, 86).

As for dissolution of foraminifera, the conserved cores were oxidized during a year of storage, and the oxidation could have been accompanied by dissolution of calcareous foraminiferal tests. The oxidation was evidenced by the orange color of sandy deposits at the time of sampling in 2010 (figs. 3-7); these depostis were gray when logged freshly cored in 2009.

\section{Chronology}

The tidal-marsh history inferred in the next section draws on radiocarbon analyses (table 1) that provide age control for the main environmental changes marked by contacts in figure 2 . In this history, a river floodplain and channel became a tidal marsh sometime after about 10,000 cal yr B.P.; the tidal marsh became an open bay about 8,500 cal yr B.P., and then a gravelly channel migrated into the Aberdeen area about 1,000 cal yr B.P.

\section{Inferred Tidal-Marsh History}

\section{Earliest Holocene Tidal Marshes in the Dry- Dock Area}

Tidal marshes colonized floodplains and bars of an ancestral Chehalis River no earlier than 10,000 cal yr B.P. The marshes likely originated after 10,500-10,200 cal yr B.P. in the Hoquiam area and after 10,200-9,700 cal yr B.P. at Aberdeen (fig. 15A).

How long after depends on the plant remains that gave these two ages. It is hoped they contain neither the interior wood from long-lived trees nor any roots injected into the fluvial sand and gravel. Even in this optimal case, however, centuries may have elapsed between deposition of the highest fluvial sand and deposition of the lowest peaty mud above it. The dating would then provide limiting-maximum ages for fluvial deposition of the sand and gravel and looser limitingmaximum ages for the onset of tidal-marsh conditions.

\section{Lifespan of the Persistent Early Holocene Marshes}

How long the marshes persisted becomes important below as an ancient analog for tidal-marsh survival in the 21 st century and as a clue to when ruptures on the Cascadia plate-boundary failed to cause enough subsidence at Grays Harbor to drown its tidal marshes. The lifespans estimated here are clouded by uncertainties in stratigraphy and dating from the reconnaissance level of our work with the dry-dock borings.

The marshes almost certainly persisted many hundreds of years. Suppose that (1) the $10 \mathrm{~m}$ of peaty mud in the Hoquiam borings $\mathrm{H} 2$ and $\mathrm{H} 4$ truly lacks intercalated tidal-flat deposits, (2) little or no additional peaty mud was removed by erosion at that unit's upper contact, and (3) the vertical marsh accretion rates were in the range $2 / 3 \mathrm{~cm} / \mathrm{yr}$ to $2 \mathrm{~cm} / \mathrm{yr}$ on average. Under these simplifying assumptions, the persistent marshes spanned between 1,500 years if they built up $2 / 3 \mathrm{~cm} / \mathrm{yr}$ on average, 1,000 years at $1 \mathrm{~cm} / \mathrm{yr}$, and 500 years at $2 \mathrm{~cm} / \mathrm{yr}$ (fig. $15 F$ ). Those accretion rates bracket most of the average rates of early Holocene sea-level rise reviewed above under the heading "Rapid Submergence in the Early Holocene" (p. 3).

However, the early Holocene tidal marshes lasted longer at some sites than at others. During deposition of the thick unit of peaty mud, marshes apparently avoided becoming tidal flats or tidal creeks at three of the borehole sites $(\mathrm{H} 1, \mathrm{H} 2, \mathrm{H} 4)$ but were interrupted by times when mud accumulated at two others (H3, A3), and peaty mud a few meters farther upsection suggests re-establishment of tidal marshes at still another site (A1) (fig. 2). The limited lateral extent of the muddy intervals in $\mathrm{H} 3$ and $\mathrm{A} 3$ suggests 
accumulation in localized tidal creeks rather than on an extensive tidal flat. It is unlikely that the interruptions at $\mathrm{H} 3$ and $\mathrm{A} 3$ extend through all of the borings but were overlooked in $\mathrm{H} 1, \mathrm{H} 2, \mathrm{H} 4$, and A1. Phipps was looking for muddy intervals above buried marsh soils when he logged the fresh cores in 2009. He had observed buried-soil evidence for coseismic subsidence in low-tide exposures of late Holocene deposits at Grays Harbor and Willapa Bay. He recorded the muddy intervals in boreholes $\mathrm{H} 3$ and $\mathrm{A} 3$ as well as a further interruption in borehole A1.

Still, the degree of marsh persistence is difficult to establish from the field logs alone (fig. 2). The diatom assemblages in the conserved cores from borings $\mathrm{H} 2$ and $\mathrm{H} 4$ give evidence against the maintenance of highmarsh conditions during the last decades recorded by the thick peaty mud (fig. 14). It would take conserved cores throughout the thick sections of peaty mud in borings $\mathrm{H} 1, \mathrm{H} 2$, and $\mathrm{H} 4$ to show whether these sections represent marshes that never drowned, and to clarify what this peaty mud implies for marsh survival in the 21 st century and for early Holocene earthquake history.

\section{Demise of the Persistent Early Holocene Marshes}

When and how the persistent marshes drowned becomes important below in judging which, if any, of the early Holocene ruptures on the Cascadia plate-boundary caused subsidence that drowned tidal marshes at Grays Harbor ( $p$. 29-30). The persistent marshes were replaced by intertidal and subtidal conditions $8,600-8,400$ cal yr B.P. if nearly uninterrupted deposition produced a conformable contact on top of the peaty mud, or later by an unknown amount of time if channels cut into the contact. If the contact is erosional, clues to the time, rate, and cause of drowning have probably been removed.

\section{Maximum Age Inferred from Radiocarbon Dating}

The persistent early Holocene marshes were widely drowned no earlier than $8,600-8,400$ cal yr B.P. This constraint is provided by four of the five ages available on the uppermost centimeters of peaty mud at depths between 25 and $30 \mathrm{~m}$ below present sea level. In four boreholes this peaty mud gave ages in the round-number range 8,600 8,400 cal yr B.P. (H1, H2, H4, A4), but in the fifth borehole, the range was 9,000-8,600 cal yr B.P. (A2) (fig. 15B).

The dated material in all five samples probably contained detritus that predates deposition as well as herbaceous roots and rhizomes that postdate it. Whichever predominated, the age of the dated material likely differs from the time of deposition by less than 50 years under two assumptions: (1) the tidal-marsh plants in the vicinity produced most of the detritus as well as all the roots and rhizomes, and (2) the marsh was aggrading nearly $1 \mathrm{~cm} / \mathrm{yr}$, apace with early Holocene sea-level rise.
Under the second assumption, marsh-plant roots had to extend nearly a half meter deep to contaminate the deposits that mark the marsh surface from a half century before. The likely plant species were the dominant sedges of today's fresh and brackish tidal marshes of upper Grays Harbor: Carex obnupta, which prefers freshwater; and Carex lyngbyei, which tolerates brackish water (Weinmann and others, 1984, p. 34). The below-ground stems of these sedges reach depths as great as $30 \mathrm{~cm}$ beneath tidal-creek banks that we have excavated. The roots attached to these rhizomes can extend another few decimeters deeper.

\section{Evidence For and Against Erosion into the Top of the Thick Peaty Mud}

The varied diatom assemblages in the mud and sand of the conserved cores are consistent with deposition in channels. The diatom assemblages suggest differences between Aberdeen and Hoquiam in water depth and additional paleoecological differences between adjoining cores. Such variability might be expected of tidal flats that are laced with rills and creeks. A landscape of this kind, in a largely freshwater setting, prevailed near Portage, Alaska, in the first few years after the 1964 earthquake (Ovenshine and others, 1976; Atwater and others, 2001). Another possible analog is the 19th-century channel near the area of the Hoquiam boreholes. At low tide this channel was $0.5 \mathrm{~km}$ wide and as much as $6 \mathrm{~m}$ deep, and its floor was made of sand, mud, and minor gravel (fig. $1 G, H$ ). If such a channel (or channels) migrated through the Hoquiam borehole area in the first few thousand years after 8,600-8,400 cal yr B.P., a channel bottom could have extended to, or eroded below, the original top of the thick peaty mud. Filling of the channel could then contribute to the variability seen in the diatom assemblages.

Three additional lines of evidence, however, fail to confirm channel erosion into the highest of the thick peaty mud:

1. Gravel is scarce or absent above the contact. In this respect the contact has more in common with the bed of the historical channel in figure $1 G$ than with the late Holocene unconformity in Aberdeen (fig. 2).

2. Differential settlement may explain the relief on the top of the peaty mud. The relief between the Aberdeen borings and the Hoquiam borings is as much as $2 \mathrm{~m}$, with Aberdeen having the highest contact in boring A2 (figs. 2, 14). However, the contact is lowest where the underlying peaty mud is thickest, at Hoquiam, as might be expected from loading by tens of meters of overlying sand and mud and consequent compaction of the peaty mud. The peaty mud may have also settled differentially from shaking-induced consolidation of the underlying sand and gravel. During the 1964 Alaska earthquake, seismic shaking locally added to coseismic tectonic subsidence by causing natural sedimentary 
deposits and railroad embankments to settle by total amounts that locally attained $1 \mathrm{~m}$ or more (Plafker, 1969, p. 34; McCulloch and Bonilla, 1970, p. 81).

3. The top of the peaty mud lacks burrows. Clams and worms can be expected to have burrowed into estuarine channel floors. Neither Phipps's field logs nor the conserved cores in figures 3-7 give evidence that clams or worms, inhabiting the floors of channels small or large, burrowed into the uppermost part of the thick peaty mud. While this absence of burrowing could be considered evidence of erosion, it might also be explained by low-salinity conditions that excluded bivalves. Most of the shells above the thick peaty mud are Macoma fragments (p. 22) that may have been transported dead by waves and currents.

\section{Unconvincing Evidence for a Tsunami}

The conserved cores lack strong evidence that a tsunami deposited sand across the top of the thick unit of peaty mud. The thick peaty mud is capped by sand in some of the boreholes, including $\mathrm{H} 2$ and $\mathrm{H} 4$. This sand is not anomalous, however, because additional sand is common in higher decimeters of H2. In neither core, moreover, does the sand contain diatom or foraminiferal evidence for a marine source (figs. 11-14). Also apparently lacking are growth-position stems and leaves of plants that were entombed before they had time to decompose.

These findings contrast with stratigraphic evidence for the 1700 Cascadia tsunami at Willapa Bay. That evidence includes anomalous sand that contains sand-flat diatoms and that surrounds rooted stems and leaves pointing in an upvalley direction (Hemphill-Haley, 1996; Atwater and Hemphill-Haley, 1997).

\section{Later Marshes and Channels}

Marshes became reestablished and produced another $3 \mathrm{~m}$ of peaty mud at the site of borehole A1 sometime between about 8,500 and 5,500 cal yr B.P. If marshes became reestablished in this time range at any of the other borehole sites, their deposits were later removed by erosion.

The most recent of the tidal marshes recorded in the cores originated before 5,800-5,600 cal yr B.P. They are known only from the Aberdeen area, where a gravelly channel intersected and likely shaved their deposits $1,200-800$ cal yr B.P. or later (fig. 2). Peaty mud below this inferred unconformity gave an age of 5,800-5,600 cal yr B.P. from boring A1, while plant remains in the overlying sand and gravel gave ages in the range $1,400-800 \mathrm{cal}$ yr B.P. from borings A2 and A4. In sparsely sampled boring A5, an age of 1,700-1,400 cal yr B.P. was obtained from plant fragments in sand about $3 \mathrm{~m}$ above the projected level of the unconformity.

\section{Implications for 21st-Century Tidal Marshes}

Early Holocene tidal marshes of Grays Harbor managed to build upward for centuries, in the manner inferred by Mudge (1862), despite submergence rates about ten times faster than those in his late Holocene case in Massachusetts (p. 1). The survival of the early Holocene marshes at Grays Harbor adds to modern examples, reviewed above (p. 3), in which tidal marshes aggraded apace with submergence that occurred at a rate about as fast as has been projected by late21 st-century forecasts.

The Grays Harbor marshes endured sustained submergence at rates probably close to $1 \mathrm{~cm} / \mathrm{yr}$ for a period of about $500-1,500$ years that ended 8,600 8,400 cal yr B.P. or perhaps later. Relative sea level was rising rapidly on many coasts between 10,000 and $8,000 \mathrm{cal}$ yr B.P. Though moderated by gravitational and tectonic effects, the area's submergence rate during those millenniums may have averaged nearly $1 \mathrm{~cm} /$ $\mathrm{yr}$, as reviewed under "Rapid Submergence in the Early Holocene" (p. 3).

Vertical accretion in these early Holocene marshes must have approached $1 \mathrm{~cm} / \mathrm{yr}$ on average in order for them to survive. This average rate is evidenced most directly by the rhythmic muddy layers in figure 4 that are about $1 \mathrm{~cm}$ thick and may be annual. The average would be greater if the peaty mud was thinned by the compaction that may be indicated by relief on the top of the peaty mud (fig. 2).

Mud brought in by riverine tides probably accounts for most of this vertical accretion. The accretion took place in the drowned valley of the Chehalis River (fig. 1D), and waters of the Chehalis likely account for the low salinities that are evidenced by diatom assemblages in the conserved cores (figs. 10,14). The peaty mud contains too little organic matter, as judged from visual inspection, for plant detritus or roots and rhizomes to have driven the vertical accretion.

\section{Implications for Earthquake History}

We now try to relate the persistence and demise of early Holocene marshes at Grays Harbor to an early part of the earthquake chronology that has been inferred from deep-sea turbidites of the past 10,000 years along the Cascadia Subduction Zone (p. 6-7). As background we first identify the deep-sea cores and ages that pertain most directly to early Holocene stratigraphy at Grays Harbor, and we review adjustments that can shift the turbidite ages by hundreds of years. We then ask which of the early Holocene turbidites may have coincided with tidal-marsh survival at Grays Harbor, and which may correlate with marsh demise. Uncertainties onshore and offshore nonetheless leave these questions open. 


\section{Pertinent Turbidites and Their Dating}

\section{Flow Paths That Head near Grays Harbor}

The deep-sea cores that pertain most directly to marsh stratigraphy at Grays Harbor are those in the paths of turbidity currents that likely originated in submarine canyons off southern Washington. One of those paths may have reached the cores at J (fig. 1A), along lower reaches of Juan de Fuca Channel, by way of the dashed line in figure $1 B$. Multiple paths fed toward the cores in area $\mathrm{C}$ of Cascadia Channel, which is the largest of the submarine channels heading along the Cascadia Subduction Zone.

We review the dating of the turbidites of these channels (in areas $\mathrm{J}$ and $\mathrm{C}$ in fig. 1A), in addition to reproducing an early Holocene part of a widely used composite sequence that incorporates evidence from farther north (at B) and south (at $\mathrm{H}$ and $\mathrm{R}$ ) as well. The local ages (from $\mathrm{J}$ and $\mathrm{C}$ ) are plotted in figure $15 D$, while the composite ages (from B, J, $\mathrm{C}, \mathrm{H}$, and $\mathrm{R}$ ) are shown in figure $15 C$.

\section{Lower Juan de Fuca Channel}

Juan de Fuca Channel runs southeastward along the seaward edge of the subduction zone before veering southwestward to the head of Cascadia Channel. It has been assumed that Holocene flows in lower Juan de Fuca Channel, off southern Washington, originated in submarine canyons off northern Washington and followed ice-age thalwegs southward from there (Adams, 1990; Goldfinger and others, 2012).

However, stratigraphic evidence suggests instead that Holocene flows spilled onto the lower continental slope from Quinault Canyon (Barnard, 1973) and may have reached lower Juan de Fuca Channel by that shortcut (dashed line in fig. 1A,B).

We compare Grays Harbor stratigraphy with the bestdated turbidite sequence in lower Juan de Fuca Channel. Goldfinger and others (2012) reported this sequence from gravity cores and piston cores at sites M9907-11 and M990712 , which adjoin one another at point $\mathrm{J}$ in figure $1 A$.

\section{Cascadia Channel}

Thalwegs from all submarine canyons off northern and southern Washington feed into Cascadia Channel. However, canyons off southern Washington probably account for most or all of the Holocene flows that extended hundreds of kilometers down this trunk channel. This southern provenance, first inferred from turbidite mineralogy of Cascadia Channel (Griggs and Kulm, 1970), is evidenced further by north-south differences in the abundance and volcanic-ash content of post-Mazama turbidites on the continental slope (Barnard, 1973) and adjoining abyssal plain off Washington (Atwater and others, 2014).

We compare Grays Harbor stratigraphy with the turbidite sequence in Cascadia Channel that Goldfinger and others (2012) correlated among gravity and piston cores at sites M9907-23 and M9907-25. These sites are located $9 \mathrm{~km}$ from one another in the channel reach marked $\mathrm{C}$ in figure $1 \mathrm{~A}$.

\section{Composite Turbidite Sequence}

We focus more on the local turbidite sequences (at $\mathrm{J}$ and C) than on the composite 10,000-year turbidite history (excerpted in figure $15 C$ ) because the composite history incorporates debatable inferences about stratigraphic correlation and age. The inferred stratigraphic correlations discount stratigraphic differences from sediment supply to submarine canyons, selective Holocene use of ice-age flow paths, and variable sedimentary facies (Atwater and others, 2014). The ages estimated for individual turbidites commonly include large adjustments. Examples for postMazama turbidites were reviewed by Atwater and Griggs (2012, p. 17-19). Examples for earlier turbidites are illustrated in figure $15 \mathrm{D}$ and are discussed below.

Goldfinger and others (2012) named each composite turbidite $\mathrm{T} 1, \mathrm{~T} 2, \mathrm{~T} 3$, and so on, where the number after the $\mathrm{T}$ increases with relative age. To refer to individual turbidites in figure $15 D$ and supporting table 3 , we assign local turbidite names by changing the " $\mathrm{T}$ " to a " $\mathrm{J}$ " or " $\mathrm{C}$ " for lower Juan de Fuca Channel and Cascadia Channel, respectively. This change reduces built-in inference about stratigraphic correlations among widely separated cores (Atwater and Griggs, 2012, p. 5-6). We use J15a to denote a previously unnamed turbidite identified in cores from lower Juan de Fuca Channel.

\section{Adjustments to Turbidite Ages}

The typical turbidite age of Goldfinger and others (2012) is derived from the radiocarbon age of planktic foraminifera that underlie the turbidite. These microscopic calcareous fossils formed part of the hemipelagic deposits that had slowly accumulated before the sea floor was overrun by a turbidity current. To obtain enough carbon for dating, it was necessary to aggregate $600-1,000$ foraminifera from hemipelagic samples that span hundreds of years.

This dating strategy, introduced by Gutierrez-Pastor and others (2009), requires adjustments for the radiocarbon age of ocean water, known as a reservoir correction; for time spanned by the hemipelagic sample, estimated from the sample thickness; and for the time gap, if any, between the top of the sample interval and the former top of the hemipelagic deposit, in the event that this deposit was eroded by the flow that laid down the turbidite to be dated.

The corrections for time span and time gap commonly add up to a few hundred years for Holocene turbidites of lower Juan de Fuca Channel and Cascadia Channel, for the past 4,000 years (Atwater and Griggs, 2012, their figs. 7 and 8) and for the time window 10,000-7,000 cal yr B.P. (fig. 15D). The corrections are commonly large because the hemipelagic sediment accumulated slowly, at rates close to $1 \mathrm{~cm}$ per $100 \mathrm{yr}$ (Goldfinger and others, 2012, p. 18), relative to the typical sample thicknesses of 2 or 3 centimeters and estimated erosion in the range $0-5 \mathrm{~cm}$. 
A Plant fragments in fluvial sand below lowest tidal-marsh deposits in Hoquiam and Aberdeen

$\boldsymbol{B}$ Peaty mud in uppermost centimeters of early Holocene tidal-marsh deposits in Hoquaim and Aberdeen (figs. 2-4, 6, 7)

C Correlated turbidites dated by combining adjusted ages in $\boldsymbol{D}$ with adjusted ages from other deep-sea channels

$\boldsymbol{D}$ Individual turbidites of Juan de Fuca Channel (J) and lower Cascadia Channel (C)

Maximum age $\ldots \ldots \ldots \ldots \ldots \ldots \ldots \ldots$
Estimated erosion (cm)
into underlying hemipelagic deposits
Adjusted age $\ldots \ldots \ldots \ldots \ldots \ldots \ldots \ldots \ldots$
Mean of two adjusted ages $\ldots \ldots \ldots \ldots \ldots \square$
Age from thickness and sedimentation
rates of hemipelagic deposits $\ldots \ldots \ldots \ldots \square$

$\boldsymbol{E}$ Meltwater pulse from drainage of Lake Agassiz Dated with marine cores offshore eastern Canada Bounding ages on 4-m rise in relative sea level in The Netherlands

$\boldsymbol{F}$ Implications for Grays Harbor

Persistent early Holocene marshes

Birth no earlier than ages in $\boldsymbol{A}$.

Lifespan if marshes drowned 8,500 cal yr B.P. after aggrading $10 \mathrm{~m}$ at these rates:

Death at or after most times in $\boldsymbol{B}$.

\section{Abrupt submergence}

Coseismic subsidence, if correlated with $\boldsymbol{C}$

Sea-level rise from meltwater pulse in $\boldsymbol{E}$

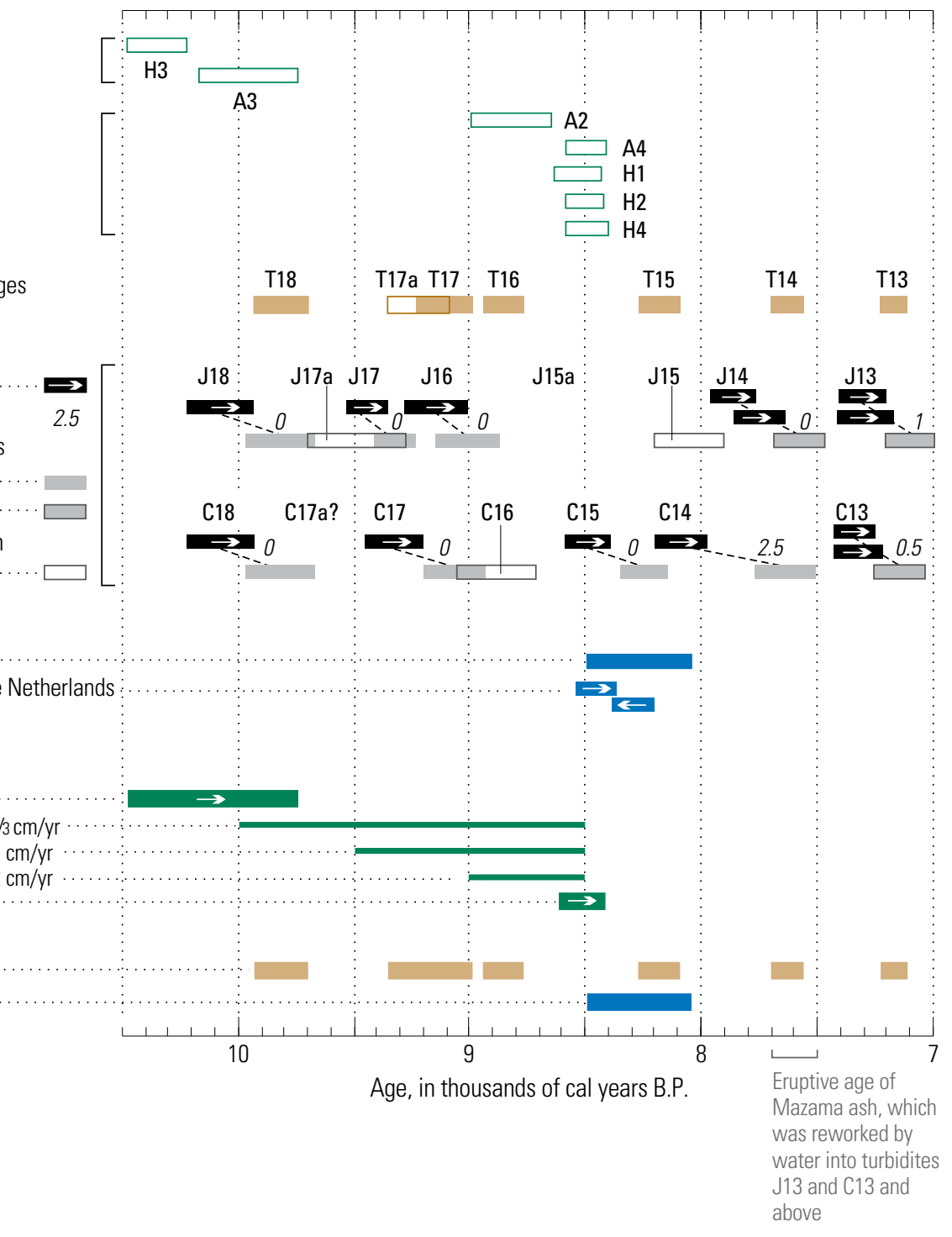

$\boldsymbol{G}$ Deep-sea cores from which most of the tubidite ages in $\boldsymbol{D}$ were derived

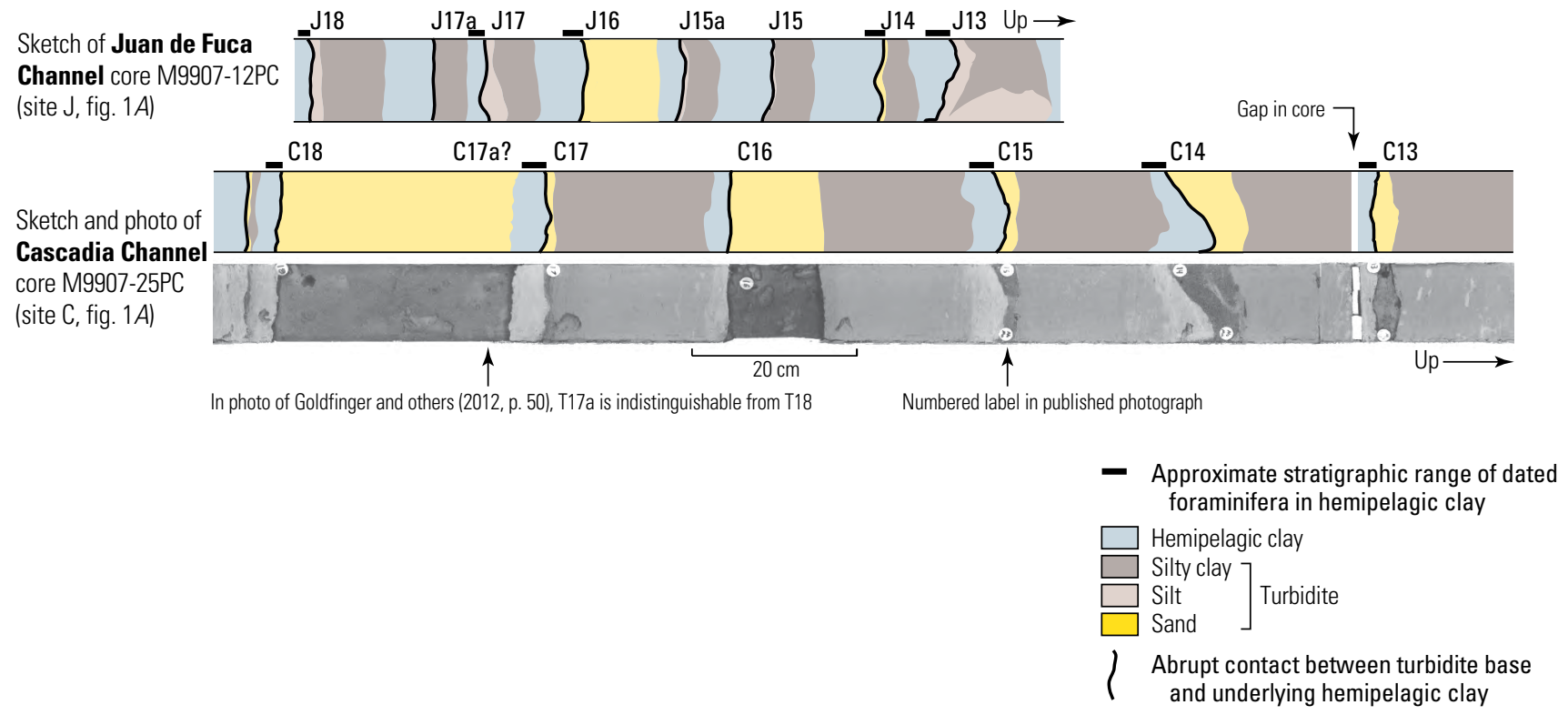


Table 3. Age estimates for early Holocene turbidites from deep-sea cores in Juan de Fuca Channel and Cascadia Channel.

[Data from Goldfinger and others (2012, appendix 1). All ranges in cal yr B.P. are quoted at two standard deviations. Bolded ranges are plotted in figure $15 D$. --, no data. Italicized ranges were estimated from thickness and sedimentation rate of hemipelagic deposits]

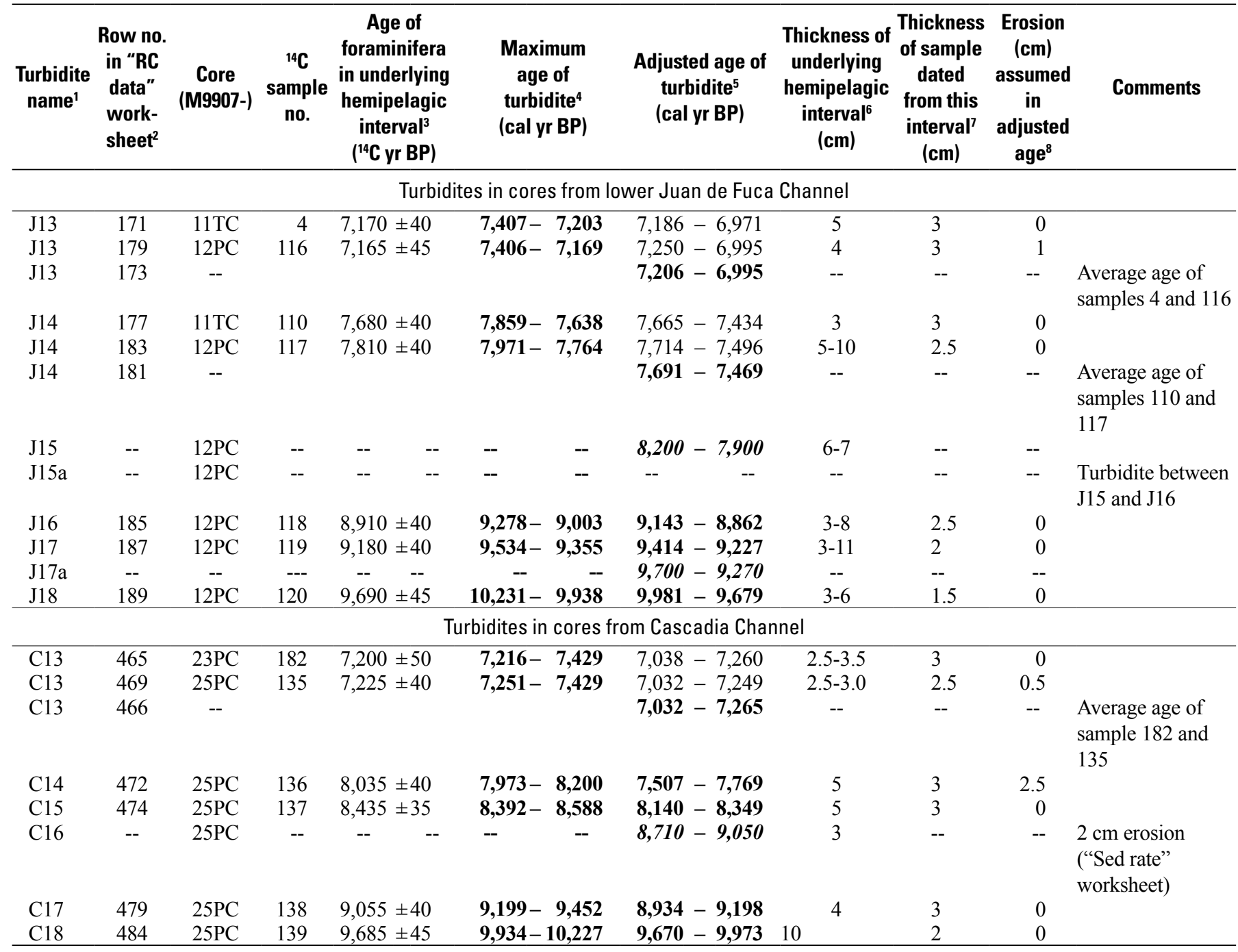

'J, Juan de Fuca Channel; C, Cascadia Channel (core locations, fig. 1A). Goldfinger and others (2012) correlated the like-numbered turbidtes and labeled them identically, as in using T16 for both J16 and C16. They called J15a a "small uncorrelated event."

${ }^{2}$ Goldfinger and others (2012, appendix 1).

${ }^{3}$ Material dated consists of foraminiferal tests from hemipelagic deposits beneath turbidite.

${ }^{4}$ Includes corrections for estimated reservoir age only. Columns U and T of "RC data" worksheet of Goldfinger and others (2012, appendix 1).

${ }^{5}$ Includes additional corrections for estimated differences between foraminiferal age and turbidite age. In Goldfinger and others (2012), the ranges in this column are plotted on pages 43 and 49, and they are derived from columns AH and AI of "RC data" worksheet.

"Sed rate curve" worksheets.

${ }^{7}$ Column F of "RC data" worksheet.

${ }^{8}$ Columns AJ and AF of "RC data" worksheet.

Figure 15. Timelines for early Holocene marshes at Grays Harbor, deep-sea turbidites along the Cascadia Subduction Zones, and catastrophic drainage of glacial Lake Agassiz. $(\boldsymbol{A}, \boldsymbol{B})$ Ages from Grays Harbor, plotted in figure 1 and listed in table 1 . (C) Turbidite ages combined from multiple deep-sea channels (Goldfinger and others, 2012, p. 124). (D) Individual turbidite ages from Juan de Fuca and Cascadia Channels. Core sites plotted in figure 1A. Data from Goldfinger and others (2012, app. 1, "RC data"), listed in table 3. No age estimate has been offered for $\mathrm{J} 15 \mathrm{a}$, which dates between $\mathrm{J} 16$ and $\mathrm{J} 15$ by stratigraphic position. (E) Last major outburst from glacial Lake Agassiz as dated at Hudson Strait (Lewis and others, 2012) and in the Netherlands (Hijma and Cohen, 2010). (F) Interpretive summary of ages in $\boldsymbol{A}-\boldsymbol{E}$. (G) Sketches and a photograph of deep-sea cores from which most of the ages in $\boldsymbol{D}$ were derived. 
Effects of these corrections on the early Holocene turbidite chronology of Juan de Fuca Channel and Cascadia Channel can be seen in figure $15 \mathrm{D}$ as the dashed-line shift from the "maximum age" (black rectangle with arrow) to "adjusted age" (gray rectangle). The "maximum age" in this diagram is the minimally adjusted age of a collection of foraminiferal tests. By stratigraphic superposition this age is greater than that of the overlying turbidite, provided that the reservoir correction is accurate. The "adjusted age" contains corrections that were intended to shift the age closer to the time of turbidite deposition.

The resulting, adjusted turbidite ages may still err on the old side. The adjusted ages, according to Goldfinger and others (2012, p. 25), "are most likely slightly biased toward older ages even after sample thickness gap and erosion corrections are made, because the known sources of error that would yield a systematic younger bias are few and numerous factors could yield a systematic older bias. These known sources of error include basal erosion, bioturbation, foraminifera reworking, undetected turbidite-tail mixing with hemipelagic sediment, and undetected turbidite tail contamination during sampling."

Where radiocarbon ages on underlying hemipelagic foraminifers are unavailable, Goldfinger and others (2012) estimated turbidite ages from hemipelagic sedimentation rates. The thicknesses of hemipelagic intervals give the approximate time elapsed before or after the deposition of a dated horizon. Ages derived this way are plotted as white rectangles in figure $15 D$ and listed in italics in table 3.

\section{Reservoir Correction to Foraminiferal Ages}

The turbidite ages plotted in figure 15 incorporate a standard correction for the approximate age of the near-surface sea water in which the dated foraminiferal tests formed. Goldfinger and others (2012, p. 17) applied standard reservoir corrections that were measured on marine shells from the decades before hydrogen-bomb testing.

Goldfinger and others (2012, p. 17-22) checked for temporal change in marine-reservoir ages at Cascadia during the past 5,000 years. Comparing deep-sea and coastal ages of what they inferred to be the same earthquake, they estimated that late Holocene surficial ocean waters were as much as a few hundred years older, relative to atmospheric carbon, than under pre-bomb historical conditions. This same approach could be applied to earlier earthquake-related turbidites if they can be securely correlated with well-dated coastal marsh stratigraphy.

\section{Adjustments for Sample Thickness and Erosion}

Most of the ages for early Holocene turbidites of Juan de Fuca Channel and Cascadia Channel were derived from foraminiferal samples $2-3 \mathrm{~cm}$ thick (table 3 ). This thickness typically spans half or more of the preserved hemipelagic interval (black bars, fig. 15G) and nearly all of the preserved hemipelagic interval in each of the five examples from Cascadia Channel. If the hemipelagic interval escaped erosion, the dated foraminfera typically represent half or more of the time interval between the successive turbidites.

Goldfinger and others (2012, appendix 1) assumed no erosion into the hemipelagic deposits beneath most of the turbidites that they dated to the interval 10,0007,000 cal yr B.P. in Juan de Fuca Channel and Cascadia Channel (table 3). The exceptions are the erosion estimates of $0.5 \mathrm{~cm}$ beneath turbidite $\mathrm{C} 13,1 \mathrm{~cm}$ beneath $\mathrm{J} 13$, and $2.5 \mathrm{~cm}$ beneath $\mathrm{C} 14$ (numerals beside diagonal dashed lines, fig. 15D).

\section{Limiting Ages from Reworked Mazama Ash}

Goldfinger and others (2012) strengthened the dating and correlation of early Holocene turbidites in figure $15 G$ by analyzing turbidite samples for reworked Mazama ash. The Mazama ash erupted about 7,700-7,500 cal yr B.P. (Hallett and others, 1997; Zdanowicz and Zielinski, 1999). The Columbia River delivered it to the sea (Peterson and others, 2012), and turbidity currents carried it to the abyssal plain (Nelson and others, 1968). Measurements of ash content show that turbidites $\mathrm{J} 13$ and $\mathrm{C} 13$ are the lowest in lower Juan de Fuca Channel and Cascadia Channel, respectively, that contain the Mazama ash (Goldfinger and others, 2012, p. 43,49$)$.

\section{Offshore-Onshore Comparisons for the Interval $10,000-8,000$ cal yr B.P.}

\section{Turbidites that May Correlate with Marsh Survival at Grays Harbor}

The centuries when early Holocene marshes persisted at Grays Harbor may include the times of one to five turbidity currents in lower Juan de Fuca Channel and in Cascadia Channel (fig. 15D,F). Although one of the flows may correspond to the demise of the persistent marshes, it is unclear whether the marshes underwent coseismic subsidence coincident with any earlier deep-sea flow. If the marshes did subside during an earthquake, or earthquakes, long before they eventually drowned, this prior subsidence produced no environmental change that registered as a widespread, conspicuous interval of mud or sand within the thick unit of peaty mud in the dry-dock borings. This possible subsidence could have resembled the instances in the past few thousand years (p. 6), in which tidal marshes in southwest Washington were lowered abruptly, but not by enough to change into unvegetated tidal flats.

\section{Turbidites of Lower Juan de Fuca Channel}

An early Holocene turbidite sequence in lower Juan de Fuca Channel contains seven turbidites younger than 10,000 cal yr B.P. below the Mazama-bearing J13 
(fig. 15D,G). Goldfinger and others (2012) identified these turbidites in piston cores M9907-11PC and M9907-12PC, and they dated them in M9907-12PC (fig. 15G).

Comparison of parts $D$ and $F$ of figure 15 shows that as many as five of these pre-Mazama turbidites may date from the time of the persistent marshes at Grays Harbor. If the marshes lasted 1,500 years, their lifespan contains, or at least overlaps with, the maximum and adjusted ages of turbidites $\mathrm{J18}, \mathrm{J17} \mathrm{a}, \mathrm{J17}$, J16, and perhaps J15a. Two or three of these turbidites (J17, J16, and perhaps J15a) similarly overlap with a 1,000-year lifespan and only one or two (J16 and perhaps J15a) with a 500-year lifespan.

\section{Turbidites of Cascadia Channel}

Five or six Holocene turbidites younger than 10,000 cal yr B.P. predate Mazama-bearing C13 in a Holocene turbidite sequence of lower Cascadia Channel (fig. 15D). C18, C17, C16, C15, and C14 are evident in the core sketch and photo of M9907-25PC in figure 25 of Goldfinger and others (2012), excerpted in our figure $15 G$. These five are also evident $9 \mathrm{~km}$ downstream in M990723PC (Goldfinger and others, 2012, fig. 24). A sixth turbidite, C17a, was reported by Goldfinger and others (2012, fig. 25) but appears amalgamated with the upper part of $\mathrm{C} 18$ in M9907-25PC (fig. 15G). A seventh possibility would be a turbidite correlative with J15a, but Goldfinger and others (2012) found no J15a correlative in Cascadia Channel.

As many as five of these pre-Mazama turbidites may date from the time of the persistent marshes at Grays Harbor (fig. 15D,F). A 1,500-year marsh lifespan would overlap, at least in part, with the estimated ages of turbidites $\mathrm{C} 18$, $\mathrm{C} 17$, and $\mathrm{C} 16$; of the doubtful $\mathrm{C} 17 \mathrm{a}$; and perhaps also of the young $\mathrm{C} 15$. As many as four $(\mathrm{C} 17, \mathrm{C} 16$, and perhaps $\mathrm{C} 17 \mathrm{a}$ and $\mathrm{C} 15$ ) similarly fit within a 1,000-year lifespan, while one or two (C16 and perhaps $\mathrm{C} 15)$ intersect a 500-year lifespan.

\section{Turbidites in the Composite Sequence}

The ages combined for four of the turbidites correlated widely by Goldfinger and others (2012) - T18, T17a, T17, and T16 (fig. $15 C$ ) —overlap a 1,500-year lifespan of early Holocene marshes at Grays Harbor (fig. $15 F$ ). As with the individual turbidite ages, fewer of these composite ages overlap with the 1,000-year lifespan, and only T16 aligns with the 500-year lifespan.

\section{Turbidites that May Correlate with Marsh Demise at Grays Harbor}

Did subsidence during an unusually large earthquake around 8,600-8,400 cal yr B.P. cause the drowning of early Holocene marshes that had persisted for an estimated 5001,500 years at Grays Harbor? This explanation is appealing in two ways: (1) Coseismic subsidence provides a simple, though equivocal, explanation for the upward termination of the thick unit of peaty mud (fig. 16). Coseismic subsidence has a demonstrated history, reviewed above, of having lowered the area's landscape by $1 \mathrm{~m}$ or more, and of having

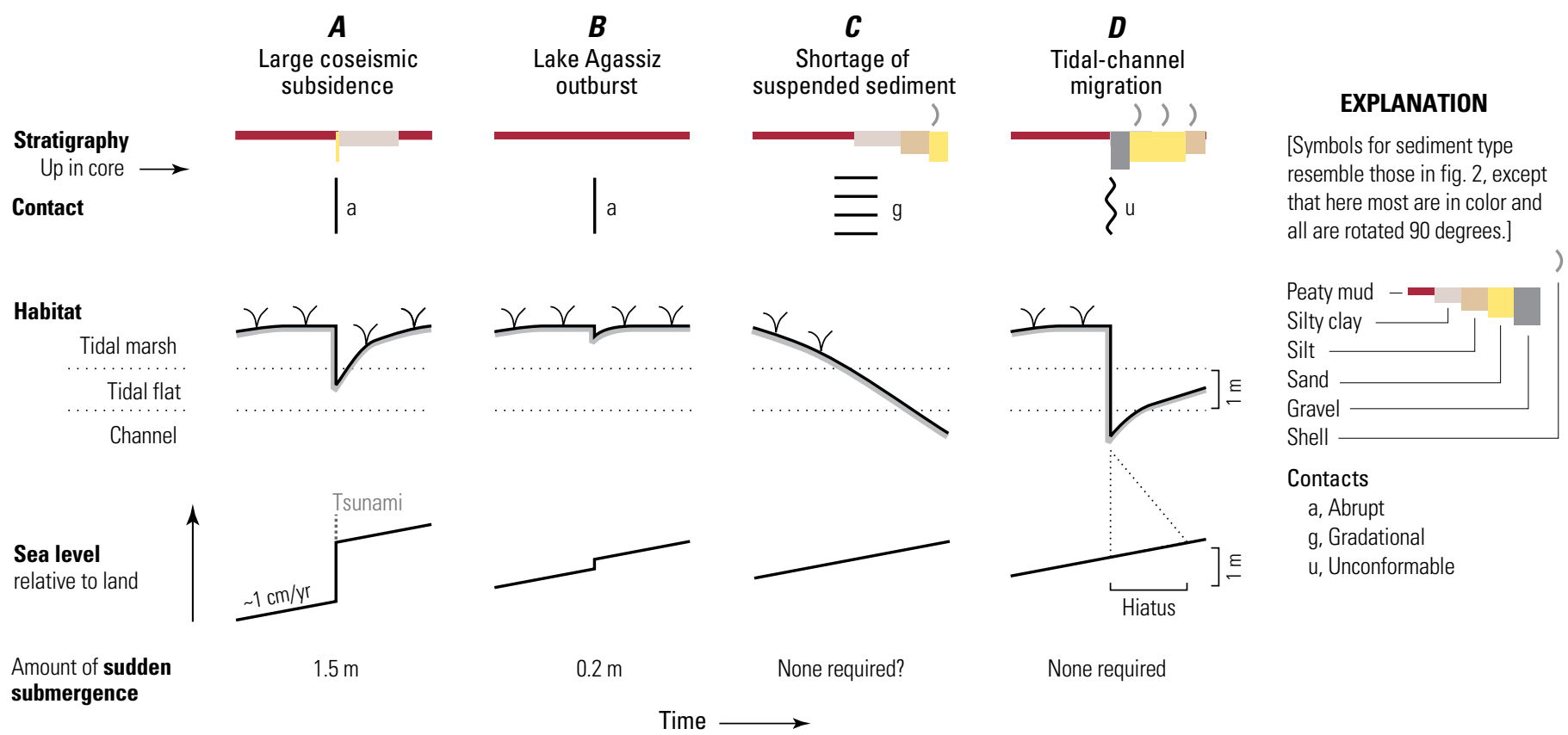

Figure 16. Diagrams illustrating hypothetical causes of the drowning and burial of early Holocene tidal-marsh deposits at Grays Harbor. 
changed Grays Harbor tidal marshes into tidal flats (p.6). (2) Deep-sea turbidites provide evidence for an unusually large earthquake that was previously assigned to the centuries before 8,600-8,400 cal yr B.P. Although at first blush this earthquake appears to predate the eventual marsh drowning that dates to $8,600-8,400$ cal yr B.P. or later ("Death" in fig. $15 F$ ), uncertainties in the turbidite dating are large enough for the inferred earthquake and the eventual drowning to overlap in estimated age.

Non-seismic causes of drowning, however, are difficult to rule out. The Agassiz outburst, variously dated to $8,500-8,000$ or $8,600-8,300$ cal yr B.P. (fig. $15 E$ ), could have abetted the marsh drowning by raising sea-level at Grays Harbor a few tenths of a meter (p. 3, 5). Rapidly rising seas may have diluted supplied sediment if, as sea level rose rapidly from a position about $30 \mathrm{~m}$ below their present level (peaty mud ages and depths, fig. 2), early Holocene Grays Harbor expanded rapidly across a gently sloping area between the Pleistocene Chehalis River valley and the Holocene tidal limit (between the solid blue line and the green line in fig. 1D). Climatic factors may have been involved as well, as in a Mississippi River delta case in which drought coincided with extensive dieback of salt marshes during the year 2000 (McKee and others, 2004). Channel erosion alone may explain the typical abruptness of the contact at the top of the thick peaty mud (p. 8, 10, 23-24). Conversely, if this contact is locally gradational (p. 14), the drowning may have been too gradual for coseismic subsidence.

These caveats aside, the hypothesis of coseismic subsidence from an unusually large earthquake implies correlations with deep-sea turbidites that are far from straightforward. Turbidites need to be related to earthquake size, and previous estimates of turbidite ages would need to be revised.

\section{Turbidite Evidence for an Unusually Large Earthquake}

Goldfinger and others (2012) estimated relative sizes of inferred earthquakes by assuming that earthquake size controls the abundance of sand and coarse silt in the lower divisions of turbidites. They reasoned that the larger the earthquake, the stronger and more long-lasting the shaking, the greater the resulting slope failures in submarine canyons, and the sandier the turbidity currents that these failures initiate. Logs of sediment density provided an index of turbidite mass that expresses the abundance of sand and coarse silt in four cores - one each at sites $\mathrm{J}, \mathrm{C}, \mathrm{H}$, and $\mathrm{R}$ of figure $1 A$ (Goldfinger and others, 2012, p. 81). A similar approach has been calibrated to estimates of historical earthquake intensity in south-central Chile (Moernaut and others, 2014).

In this manner the turbidites correlated as T16, and dating in aggregate in the range $8,950-8,750 \mathrm{cal}$ yr B.P. (fig. 15C), have been interpreted as representing one of the largest Holocene earthquakes along the Cascadia Subduction
Zone (Goldfinger and others, 2012, p. 123). T16 ranks second overall, among 18 widely correlated Holocene turbidites, in the four-core index of turbidite mass. In one core each from Juan de Fuca and Cascadia Channels, and also in a core offshore southern Oregon, the turbidites correlated as T16 exceed all other Holocene turbidites in the mass index. The preceding turbidites correlated as T17 and $\mathrm{T} 17 \mathrm{a}$ are rated among the smallest, and the turbidites correlated as T1, assigned to the January 1700 earthquake of estimated magnitude 8.7-9.2 (Satake and others, 2003), are rated below average.

\section{Individual Turbidites of Lower Juan de Fuca Channel and Cascadia Channel}

Turbidites $\mathrm{J} 16$ and $\mathrm{C} 16$, cored along flow paths that head off southern Washington (fig. $1 A, B$ ), are among the turbidites that Goldfinger and others (2012) ascribed to an unusually large earthquake $8,950-8,750 \mathrm{cal}$ yr B.P. (T16, fig. $15 C$ ). Within uncertainties in dating, however, J16 and C16 might have been deposited 8,600-8,400 cal yr B.P.

Turbidite J16 may overlap with $8,600-8,400$ cal yr B.P. if the hemipelagic deposits beneath it were deeply eroded. Goldfinger and others (2012) dated J16 to the range 9,143-8,862 cal yr B.P. without allowing for erosion of the hemipelagic interval beneath (fig. 15D). However, they estimated that erosion removed about half the hemipelagic interval beneath turbidite $\mathrm{C} 16$, and they adjusted the age of turbidite $\mathrm{J} 8$ for an estimated $4.7 \mathrm{~cm}$ of erosion (Goldfinger and others, 2012, appendix 1, RC data, rows 146-148). The erosion correction for J8 shifted its age forward by nearly 500 years (Atwater and Griggs, 2012, their figs. 7 and 8). Turbidite J16 contains more sand than any other Holocene turbidite among the trigger and piston cores M9907-11 and M9907-12 (Goldfinger and others, 2012, p. 81). If its reported age of 9,143-8,862 cal yr B.P. were shifted 500 years forward for erosion, the age would center on $8,500 \mathrm{cal}$ yr B.P.

Turbidite C16 was previously dated to 9,050 $8,710 \mathrm{cal}$ yr B.P. on the basis of sedimentation rates only (fig. $15 D$, table 3 ). The age of $\mathrm{C} 16$ can be constrained more directly from radiocarbon dating of foraminifera that were aggregated from the entire hemipelagic interval immediately above (fig. 15G). These foraminifers gave an age of 8,5888,392 cal yr B.P. Within uncertainties from bioturbation and reservoir correction, this range permits the underlying $\mathrm{C} 16$ to have been deposited 8,600-8,400 cal yr B.P.

\section{Suggestions for Further Work}

This report calls attention to stratigraphic evidence for early Holocene tidal marshes at a Pacific coast estuary in Washington State. The evidence is notable for suggesting that marshes endured rapid sea-level rise, and for raising 
questions about the history of earthquakes on the region's largest active fault. Further study might focus on three hypotheses:

1. Sea-level rise about as fast as projected for this century failed to drown tidal marshes in an upper reach of Grays Harbor for 5001,500 years. The rate of this marsh build-up could be clarified from radiocarbon analyses scattered throughout the 10-m column of peaty mud at Hoquiam (fig. 2). The height of the persistent marsh surface, with respect to ambient sea level, could be examined in that vertical range by analysis of diatoms (as in figures 9,10, and 14) and identification of growth-position fossils of vascular plants.

2. Seismic slip on the subduction thrust off southern Washington was greater in January 1700 than in the interval 9,00010,000 cal yr B.P. The thick peaty mud from that interval could be checked for signs of coseismic subsidence that managed to lower the persistent marshes but not by enough to yield widespread, long-lasting tidal flats. The maximum ages expected are given by the ages of foraminifers beneath individual turbidites in lower Juan de Fuca Channel (beneath turbidites J18 and J17) and in Cascadia Channel (beneath $\mathrm{C} 18$ and $\mathrm{C} 17$ ).

3. One of the largest Cascadia earthquakes in the past 10,000 years occurred 8,600 8,400 cal yr B.P. or soon thereafter. The earthquake would be marked by stratigraphic evidence for coseismic subsidence at least as great as accompanied the giant Cascadia earthquake of January 1700. This evidence could be sought at estuary margins where the top of the peaty mud is likely to have escaped extensive erosion by tidal channels.

\section{References Cited}

Adams, J., 1990, Paleoseismicity of the Cascadia subduction zone- - evidence from turbidites off the OregonWashington margin: Tectonics, v. 9, no. 4, p. 569-583.

Allen, J.R.L., 1990, Salt-marsh growth and stratification-a numerical model with special reference to the Severn Estuary, southwest Britain: Marine Geology, v. 95, no. 2, p. 77-96, doi:10.1016/0025-3227(90)90042-I.

Ando, M., and Balazs, E.I., 1979, Geodetic evidence for aseismic subduction of the Juan de Fuca Plate: Journal of Geophysical Research, v. 84, no. B6, p. 3023-3028.
Atwater, B.F., 1987, Evidence for great Holocene earthquakes along the outer coast of Washington State: Science, v. 236, no. 4804, p. 942-944.

Atwater, B.F., Carson, B., Griggs, G.B., Johnson, H.P., and Salmi, M.S., 2014, Rethinking turbidite paleoseismology along the Cascadia Subduction Zone: Geology, v. 42, no. 9, p. 827-830, doi:10.1130/G35902.1.

Atwater, B., Furukawa, R., Hemphill-Haley, E., Ikeda, Y., Kashima, K., Kawase, K., Kelsey, H., Moore, A., Nanayama, F., Nishimura, Y., Odagiri, S., Ota, Y., Park, S., Satake, K., Sawal, Y., and Shimokawa, K., 2004a, Seventeenth-century uplift in Eastern Hokkaido, Japan: The Holocene, v. 14, no. 4, p. 487-501, doi:10.1191/0959683604hl726rp.

Atwater, B.F., and Griggs, G.B., 2012, Deep-sea turbidites as guides to Holocene earthquake history at the Cascadia Subduction Zone-Alternative views for a seismic-hazard workshop: U.S. Geological Survey Open-File Report 2012-1043, 58 p., accessed March 6, 2012, at http://pubs. usgs.gov/of/2012/1043/.

Atwater, B.F., and Hemphill-Haley, E., 1997, Recurrence intervals for great earthquakes of the past 3,500 years at northeastern Willapa Bay, Washington: U.S. Geological Survey Professional Paper 1576, 108 p., http://pubs.usgs. gov/pp/1576/report.pdf.

Atwater, B.F., Nelson, A.R., Clague, J.J., Carver, G.A., Yamaguchi, D.K., Bobrowsky, P.T., Bourgeois, J., Darienzo, M.E., Grant, W.C., Hemphill-Haley, E., Kelsey, H.M., Jacoby, G.C., Nishenko, S.P., Palmer, S.P., Peterson, C.D., and Reinhart, M.A., 1995, Summary of coastal geologic evidence for past great earthquakes at the Cascadia subduction zone: Earthquake Spectra, v. 11, no. 1, p. 1-18.

Atwater, B.F., Tuttle, M.P., Schweig, E.S., Rubin, C.M., Yamaguchi, D.K., and Hemphill-Haley, E., 2004b, Earthquake recurrence inferred from paleoseismology, in Gillespie, A.R., Porter, S.C. and Atwater, B.F., eds., The Quaternary Period in the United States: Elsevier, p. 331-350.

Atwater, B.F., Yamaguchi, D.K., Bondevik, S., Barnhardt, W.A., Amidon, L.J., Benson, B.E., Skjerdal, G., Shulene, J.A., and Nanayama, F., 2001, Rapid resetting of an estuarine recorder of the 1964 Alaska earthquake: Geological Society of America Bulletin, v. 113, no. 9, p. 1193-1204, doi:10.1130/0016-7606(2001)113 $<1193$ :RROAER>2.0.CO;2.

Barnard, W.D., 1973, Late Cenozoic sedimentation on the Washington continental slope: Seattle, University of Washington, Ph.D. dissertation, 255 p.

Benson, B.E., Atwater, B.F., Yamaguchi, D.K., Amidon, L.J., Brown, S.L., and Lewis, R.C., 2001, Renewal of tidal forests in Washington State after a subduction earthquake in A.D. 1700: Quaternary Research, v. 56, no. 2, p. 139-147. 
Bolles, T.D., Jordan, J.N., Purcell, J.L., and McHenry, J., 1883, Entrance to Grays Harbor, Washington Territory: U.S. Coast and Geodetic Survey, Hydrographic Sheet H-1589, scale 1:20,000.

Bretz, J.H., 1913, Glaciation of the Puget Sound region: Washington Division of Mines and Geology Bulletin 8, 244 p.

Bretz, J.H., Smith, H.T.U., and Neff, G.E., 1956, Channeled Scabland of Washington - new data and interpretations: Geological Society of America Bulletin, v. 67, no. 8, p.957-1049, doi:10.1130/0016-7606(1956)67[957:CSOW $\mathrm{ND}] 2.0 . \mathrm{CO} ; 2$.

Burgette, R.J., Weldon, R.J., and Schmidt, D.A., 2009, Interseismic uplift rates for western Oregon and alongstrike variation in locking on the Cascadia subduction zone: Journal of Geophysical Research, v. 114, no. B1, p. B01408, doi:10.1029/2008JB005679.

Cisternas, M., Atwater, B.F., Torrejon, F., Sawai, Y., Machuca, G., Lagos, M., Eipert, A., Youlton, C., Salgado, I., Kamataki, T., Shishikura, M., Rajendran, C.P., Malik, J.K., Rizal, Y., and Husni, M., 2005, Predecessors of the giant 1960 Chile earthquake: Nature, v. 437, no. 7057, p. 404407, doi:10.1038/nature03943.

Clague, J.J., 1983, Glacio-isostatic effects of the Cordilleran ice-sheet, British Columbia, Canada, in Smith, D.E., and Dawson, A.G., eds., Shorelines and isostasy: London; New York, Academic Press, p. 321-343.

Committee on Sea Level Rise in California, Oregon, and Washington, 2012, Sea-level rise for the coasts of California, Oregon, and Washington-Past, present, and future: National Research Council, 202 p., http:/www.nap. edu/catalog/13389.

Couvillion, B.R., Barras, J.A., Steyer, G.D., Sleavin, W., Fischer, M., Beck, H., Trahan, N., Griffin, B., and Heckman, D., 2011, Land area change in coastal Louisiana from 1932 to 2010:, U.S. Geological Survey Scientific Investigations Map 3164, scale 1:265,000, pamphlet 12 p., http://pubs.usgs.gov/sim/3164/.

Cronin, T.M., Vogt, P.R., Willard, D.A., Thunell, R., Halka, J., Berke, M., and Pohlman, J., 2007, Rapid sea level rise and ice sheet response to 8,200-year climate event: Geophysical Research Letters, v. 34, no. 20, p. L20603, doi:10.1029/2007GL031318.

Cronin, T.M., 2012, Rapid sea-level rise: Quaternary Science Reviews, v. 56, p. 11-30, doi:http://dx.doi.org/10.1016/j. quascirev.2012.08.021.

De Sève, M.A., 1993, Diatom bloom in the tidal freshwater zone of a turbid and shallow estuary, Rupert Bay (James Bay, Canada): Hydrobiologia, v. 269/270, p. 225-233, doi:10.1007/BF00028021.
Donnelly, J.P., 2006, A revised late Holocene sea-level record for northern Massachusetts, USA: Journal of Coastal Research, v. 22, no. 5, p. 1051-1061, doi:10.2112/040207.1.

Doughton, S., 2013, Full-rip 9.0 - the next big earthquake in the Pacific Northwest: Seattle, Sasquatch Books, 288 p.

Fagherazzi, S., Kirwan, M.L., Mudd, S.M., Guntenspergen, G.R., Temmerman, S., D’Alpaos, A., van de Koppel, J., Rybczyk, J.M., Reyes, E., Craft, C., and Clough, J., 2012, Numerical models of salt marsh evolutionecological, geomorphic, and climatic factors: Reviews of Geophysics, v. 50, no. 1, p. RG1002, doi:10.1029/2011RG000359.

Galloway, D.L., Jones, D.R., and Ingebritsen, S.E., 1999, Land subsidence in the United States: U.S. Geological Survey Circular 1182, 174 p., http://pubs.usgs.gov/circ/circ1182/.

Gilbert, G.K., 1908, Tomales Bay to Bolinas Lagoon, in Lawson, A.C., ed., The California earthquake of April 18, 1906; Report of the State Earthquake Investigation Commission: Washington, D.C., Carnegie Institution of Washington Publication no. 87, v. I, part I, p. 66-91.

Glick, P., Clough, J., Polaczyk, A., Couvillion, B., and Nunley, B., 2013, Potential effects of sea-level rise on coastal wetlands in southeastern Louisiana: Journal of Coastal Research, v. special issue 63, p. 211-233, doi:10.2112/SI63-0017.1.

Goldfinger, C., Ikeda, Y., Yeats, R.S., and Ren, J., 2013, Superquakes and supercycles: Seismological Research Letters, v. 84, no. 1, p. 24-32, doi:10.1785/0220110135.

Goldfinger, C., Nelson, C.H., Johnson, J.E., Morey, A.E., Guitérrez-Pastor, J., Karabanov, E., Eriksson, A.T., Gràcia, E., Dunhill, G., Patton, J., Enkin, R., Dallimore, A., and Vallier, T., 2012, Turbidite event history-methods and implications for Holocene paleoseismicity of the Cascadia subduction zone: U.S. Geological Survey Professional Paper 1661-F, 170 p., accessed February 25, 2012 , at http://pubs.usgs.gov/pp/pp1661f/.

Griggs, G.B., and Kulm, L.D., 1970, Sedimentation in Cascadia Deep-Sea Channel: Geological Society of America Bulletin, v. 81, no. 5, p. 1361-1384, doi:10.1130/00167606(1970)81[1361:SICDC]2.0.CO;2.

Gutierrez-Pastor, J., Nelson, C.H., Goldfinger, C., Johnson, J.E., Escutia, C., Eriksson, A., and Morey, A.E., 2009, Earthquake control of Holocene turbidite frequency confirmed by hemipelagic sedimentation chronology on the Cascadia and Northern California active continental margins, in Kneller, B., Martinsen, O.J. and McCaffrey, B., eds., External controls on deep-water depositional systems: Tulsa, Okla., Society for Sedimentary Geology Special Publication 92, p. 179-197. 
Hallett, D.J., Hills, L.V., and Clague, J.J., 1997, New accelerator mass spectrometry radiocarbon ages for the Mazama tephra layer from Kootenay National Park, British Columbia, Canada: Canadian Journal of Earth Sciences, v. 34, no. 9, p. 1202-1209, doi:10.1139/e17-096.

Hawkes, A.D., Horton, B.P., Nelson, A.R., Vane, C.H., and Sawai, Y., 2011, Coastal subsidence in Oregon, USA, during the giant Cascadia earthquake of $\mathrm{AD} 1700$ : Quaternary Science Reviews, v. 30, no. 3-4, p. 364-376, doi:10.1016/j.quascirev.2010.11.017.

Hemphill-Haley, E., 1995, Diatom evidence for earthquakeinduced subsidence and tsunami $300 \mathrm{yr}$ ago in southern coastal Washington: Geological Society of America Bulletin, v. 107, no. 3, p. 367-378, doi:10.1130/00167606(1995)107<0367:DEFEIS>2.3.CO;2.

Hemphill-Haley, E., 1996, Diatoms as an aid in identifying late-Holocene tsunami deposits: The Holocene, v. 6, no. 4, p. $439-448$.

Hetherington, R., and Reid, R.G.B., 2003, Malacological insights into the marine ecology and changing climate of the late Pleistocene-early Holocene Queen Charlotte Islands archipelago, western Canada, and implications for early peoples: Canadian Journal of Zoology, v. 81, no. 4, p. 626-661, doi:10.1139/z03-024.

Hijma, M.P., and Cohen, K.M., 2010, Timing and magnitude of the sea-level jump preluding the $8200 \mathrm{yr}$ event: Geology, v. 38, no. 3, p. 275-278, doi:10.1130/G30439.1.

Hijma, M.P., and Cohen, K.M., 2011, Holocene transgression of the Rhine river mouth area, The Netherlands/Southern North Sea - palaeogeography and sequence stratigraphy: Sedimentology, v. 58, no. 6, p. 1453-1485, doi:10.1111/ j.1365-3091.2010.01222.x.

Hinkel, J., Lincke, D., Vafeidis, A.T., Perrette, M., Nicholls, R.J., Tol, R.S.J., Marzeion, B., Fettweis, X., Ionescu, C., and Levermann, A., 2014, Coastal flood damage and adaptation costs under 21 st century sea-level rise: Proceedings of the National Academy of Sciences, v. 111, no. 9, p. 3292-3297, doi:10.1073/pnas.1222469111.

Hudak, C.M., Tocki, P.A., Bauer, W., Kesey, J., Bureau, T., and Summers, K., 2006, Technical and process review of the Hood Canal bridge and Port Angeles graving dock project, in Whitener, V., Fanning, R. and Konopaski, K., eds., Review of Port Angeles graving dock project: Olympia, Wash., Transportation Performance Audit Board, p. 1-145, accessed March 23, 2012, at http://www.leg.wa.gov/ JLARC/AuditAndStudyReports/2006/Pages/06-8.aspx.

Hustedt, F., 1957, Die Diatomeenflora des Fluss-systems der Weser im Gebiet der Hansestadt Bremen: Abhandlungen des Naturwissenschaftlichen Verein, Bremen, v. 34, no. 3 , p. $181-440$.
Hyndman, R.D., and Rogers, G.C., 2010, Great earthquakes on Canada's west coast - a review: Canadian Journal of Earth Sciences, v. 47, p. 801-820.

James, T., Gowan, E.J., Hutchinson, I., Barrie, J.V., Clague, J.J., and Conway, K.W., 2009, Sea-level change and paleogeographic reconstructions, southern Vancouver Island, British Columbia, Canada: Quaternary Science Reviews, v. 28, no. 13-14, p. 1200-1216, doi:10.1016/j.quascirev.2008.12.022.

James, T.S., Clague, J.J., Wang, K., and Hutchinson, I., 2000, Postglacial rebound at the northern Cascadia subduction zone: Quaternary Science Reviews, v. 19, no. 14-15, p. 1527-1541, doi:10.1016/S0277-3791(00)00076-7.

Kelsey, H.M., Engebretson, D.C., Mitchell, C.E., and Ticknor, R.L., 1994, Topographic form of the Coast Ranges of the Cascadia margin in relation to coastal uplift rates and plate subduction: Journal of Geophysical Research, v. 99, no. B6, p. 12245-12255, doi:10.1029/93JB03236.

Kendall, R.A., Mitrovica, J.X., Milne, G.A., Törnqvist, T.E., and Li, Y., 2008, The sea-level fingerprint of the 8.2 ka climate event: Geology, v. 36, no. 5, p. 423-426, doi:10.1130/G24550A.1.

Kintisch, E., 2013, Can coastal marshes rise above it all? Science, v. 341 , no. 6145 , p. $480-481$, doi:10.1126/ science.341.6145.480.

Kirwan, M.L., Guntenspergen, G.R., D'Alpaos, A., Morris, J.T., Mudd, S.M., and Temmerman, S., 2010, Limits on the adaptability of coastal marshes to rising sea level: Geophysical Research Letters, v. 37, no. 23, p. L23401, doi:10.1029/2010GL045489.

Komar, P.D., Allan, J.C., and Ruggiero, P., 2011, Sea level variations along the U.S. Pacific Northwest coast: tectonic and climate controls: Journal of Coastal Research, v. 27, no. 5, p. 808-823, doi:10.2112/ JCOASTRES-D-10-00116.1.

Kulkarni, R., Wong, I., Zachariasen, J., Goldfinger, C., and Lawrence, M., 2013, Statistical analyses of great earthquake recurrence along the Cascadia Subduction Zone: Bulletin of the Seismological Society of America, v. 103 , no. 6 , p. 3205-3221, doi:10.1785/0120120105.

Leonard, L.J., Currie, C.A., Mazzotti, S., and Hyndman, R.D., 2010, Rupture area and displacement of past Cascadia great earthquakes from coastal coseismic subsidence: Geological Society of America Bulletin, v. 122, no. 11-12, p. 2079-2096, doi:10.1130/B30108.1.

Leverington, D., Mann, J., and Teller, J., 2002, Changes in the bathymetry and volume of glacial Lake Agassiz between 9200 and $7700{ }^{14} \mathrm{C}$ yr BP: Quaternary Research, v. 57, no. 2, p. 244-252, doi:10.1006/qres.2001.2311. 
Lewis, C.F.M., Miller, A.A.L., Levac, E., Piper, D.J.W., and Sonnichsen, G.V., 2012, Lake Agassiz outburst age and routing by Labrador Current and the $8.2 \mathrm{cal} \mathrm{ka}$ cold event: Quaternary International, v. 260, p. 83-97, doi:10.1016/j.quaint.2011.08.023.

Lockwood, A.P.M., 1976, Physiological adaptation to life in estuaries; essays on the physiology of marine animals, in Newell, R.C., ed., Adaptation to environment: London, Butterworth-Heinemann, p. 315-392.

MacDonald, D.B., 2006, The Hood Canal Bridge rehabilitation project and graving dock program: Olympia, Wash., Washington State Dept. of Transportation, 224 .

Mapes, L., 2009, Breaking ground; the Lower Elwha Klallam tribe and the unearthing of Tse-whit-zen Village: Seattle, University of Washington Press, $240 \mathrm{p}$.

McCrory, P.A., Foster, D.S., Danforth, W.W., and Hamer, M.R., 2002, Crustal deformation at the leading edge of the Oregon Coast Range block, offshore Washington (Columbia River to Hoh River): U.S. Geological Survey Professional Paper 1661-A, 47 p., accessed April 16, 2013, at http://pubs.usgs.gov/pp/pp1661a/.

McCulloch, D.S., and Bonilla, M.G., 1970, Effects of the earthquake of March 27, 1964, on the Alaska Railroad: U.S. Geological Survey Professional Paper 545-D, 160 p., accessed May 19, 2014, at http://pubs.usgs.gov/pp/0545d/.

McKee, K., Mendelssohn, I., and Materne, M., 2004, Acute salt marsh dieback in the Mississippi River deltaic plain-a drought-induced phenomenon? Global Ecology and Biogeography, v. 13, no. 1, p. 65-73, doi:10.1111/j.1466882X.2004.00075.x.

McPhee, J., 1998, Annals of the former world: New York, Farrar, Straus and Giroux, 695 p.

Meyssignac, B., and Cazenave, A., 2012, Sea level: A review of present-day and recent-past changes and variability: Journal of Geodynamics, v. 58, no. 0, p. 96-109, doi:10.1016/j.jog.2012.03.005.

Moernaut, J., Van Daele, M., Heirman, K., Fontijn, K., Strasser, M., Pino, M., Urrutia, R., and De Batist, M., 2014, Lacustrine turbidites as a tool for quantitative earthquake reconstruction - new evidence for a variable rupture mode in south-central Chile: Journal of Geophysical Research, Solid Earth, v. 119, p. 1607-1633, doi:10.1002/2013JB010738.

Mudd, S.M., Howell, S.M., and Morris, J.T., 2009, Impact of dynamic feedbacks between sedimentation, sealevel rise, and biomass production on near-surface marsh stratigraphy and carbon accumulation: Estuarine, Coastal and Shelf Science, v. 82, no. 3, p. 377-389, doi:10.1016/j.ecss.2009.01.028.
Mudge, B.F., 1862, The salt marsh formations of Lynn: Proceedings of the Essex Institute, v. 2, p. 117-119, http://catalog.hathitrust.org/Record/000058012;

Nelson, C.H., Kulm, L.D., Carlson, P.R., and Duncan, J.R., 1968, Mazama ash in the northeastern Pacific: Science, v. 161 , no. 3836 , p. $47-49$.

Nelson, A.R., and Kashima, K., 1993, Diatom zonation in southern Oregon tidal marshes relative to vascular plants, foraminifera, and sea level: Journal of Coastal Research, v. 9 , no. 3, p. 673-697.

Nelson, A.R., Jennings, A.E., and Kashima, K., 1996, An earthquake history derived from stratigraphic and microfossil evidence of relative sea-level change at Coos Bay, southern coastal Oregon: Geological Society of America Bulletin, v. 108, no. 2, p. 141-154, doi:10.1130/00167606(1996)108<0141:AEHDFS>2.3.CO;2.

Newton, J.A., Albertson, S.L., and Thompson, A.L., 1997, Washington State marine water quality in 1994 and 1995: Washington State Department of Ecology Publication No. 97-316, 352 p., accessed May 25, 2012, at http:// www.ecy.wa.gov/pubs/97316.pdf.

Nittrouer, C.A., 1978, The process of detrital sediment accumulation in a continental shelf environment: an examination of the Washington shelf: Seattle, University of Washington, Ph.D. dissertation, 243 p.

Ovenshine, A.T., Lawson, D.E., and Bartsch-Winkler, S.R., 1976, The Placer River Silt - an intertidal deposit caused by the 1964 Alaska earthquake: Journal of Research of the U.S. Geological Survey, v. 4, p. 151-162.

Parker, J.D., 1880, Memorial of Prof. Benjamin F. Mudge: Transactions of the Kansas Academy of Science (1872), v. 7, p. 7-11, http://www.oceansofkansas.com/ bfmudge2.html.

Patrick, W.H., and DeLaune, R.D., 1990, Subsidence, accretion, and sea level rise in south San Francisco Bay marshes: Limnology and Oceanography, v. 35, no. 6, p. 1389-1395.

Peterson, C.D., and Phipps, J.B., 1992, Holocene sedimentary framework of Grays Harbor basin, Washington, U.S.A., in Fletcher, C.H., III, and Wehmiller, J.F., eds., Quaternary coasts of the United States: marine and lacustrine systems: Tulsa, Okla., SEPM [Society for Sedimentary Geology] Special Publication 48, p. 273-285.

Peterson, C., Minor, R., Gates, E.B., Vanderburgh, S., and Carlisle, K., 2012, Correlation of tephra marker beds in latest Pleistocene and Holocene fill of the submerged lower Columbia River valley, Washington and Oregon, U.S.A. Journal of Coastal Research, v. 28, no. 6, p. 1362-1380, doi:10.2112/JCOASTRES-D-11-00181.1. 
Plafker, G., 1969, Tectonics of the March 27, 1964, Alaska earthquake: U.S. Geological Survey Professional Paper 543-I, 74 p., http://pubs.usgs.gov/pp/0543i/.

Plafker, G., and Savage, J.C., 1970, Mechanism of the Chilean earthquakes of May 21 and 22, 1960: Geological Society of America Bulletin, v. 81, no. 4, p. 1001-1030, doi:10.1130/00167606(1970)81[1001:MOTCEO]2.0.CO;2.

Pope, D., 2008, Nuclear implosions - the rise and fall of the Washington Public Power Supply System: New York, Cambridge University Press, 282 p.

Porter, S.C., and Swanson, T.W., 1998, Radiocarbon age constraints on rates of advance and retreat of the Puget Lobe of the Cordilleran ice sheet during the last glaciation: Quaternary Research, v. 50, no. 3, p. 205-213, doi:10.1006/qres.1998.2004.

Pouderoux, H., Lamarche, G., and Proust, J.N., 2012, Building an 18 000-year-long paleo-earthquake record from detailed deep-sea turbidite characterisation in Poverty Bay, New Zealand: Natural Hazards and Earth System Sciences, v. 12, no. 6, p. 2077-2101, doi:10.5194/nhess-12-2077-2012.

Priest, G.R., Goldfinger, C., Wang, K., Witter, R.C., Zhang, Y., and Baptista, A.M., 2010, Confidence levels for tsunamiinundation limits in northern Oregon inferred from a 10,000-year history of great earthquakes at the Cascadia subduction zone: Natural Hazards, v. 54, p. 27-73.

Reimer, P.J., Baillie, M.G.L., Bard, E., Bayliss, A., Beck, J.W., Blackwell, P.G., Ramsey, C.B., Buck, C.E., Burr, G.S., Edwards, R.L., Friedrich, M., Grootes, P.M., Guilderson, T.P., Hajdas, I., Heaton, T.J., Hogg, A.G., Hughen, K.A., Kaiser, K.F., Kromer, B., McCormac, F.G., Manning, S.W., Reimer, R.W., Richards, D.A., Southon, J.R., Talamo, S., Turney, C.S.M., van der Plicht, J., and Weyhenmeye, C.E., 2009, IntCal09 and Marine09 radiocarbon age calibration curves, $0-50,000$ years cal BP: Radiocarbon, v. 51, no. 4, p. 1111-1150.

Riveiros, N.V., Babalola, A.O., Boudreau, R.E.A., Patterson, R.T., Roe, H.M., and Doherty, C., 2007, Modern distribution of salt marsh foraminifera and thecamoebians in the Seymour-Belize Inlet Complex, British Columbia, Canada: Marine Geology, v. 242, no. 1-3, p. 39-63, doi:10.1016/j.margeo.2006.08.009.

Rodriguez, A.B., Simms, A.R., and Anderson, J.B., 2010, Bay-head deltas across the northern Gulf of Mexico back step in response to the 8.2 ka cooling event: Quaternary Science Reviews, v. 29, no. 27-28, p. 3983-3993, doi:10.1016/j.quascirev.2010.10.004.

Roe, H.M., Doherty, C.T., Patterson, R.T., and Swindles, G.T., 2009, Contemporary distributions of saltmarsh diatoms in the Seymour-Belize Inlet Complex, British Columbia, Canada: Implications for studies of sea-level change: Marine Micropaleontology, v. 70, no. 3-4, p. 134-150, doi:10.1016/j.marmicro.2008.12.001.
Rong, Y., Jackson, D.D., Magistrale, H., and Goldfinger, C., 2014, Magnitude limits of subduction zone earthquakes: Bulletin of the Seismological Society of America, v. 104, no. 5, p. 2359-2377, doi:10.1785/0120130287.

Rude, G.T., and Smith, E.E., 1911, Grays Harbor, Hoquiam and Aberdeen, Washington: U.S. Coast and Geodetic Survey, Topographic Sheet T-3154, scale 1:10,000, http:// specialprojects.nos.noaa.gov/tools/shorelinesurvey.html.

Rudy, P., Jr., and Hay Rudy, L., 1983, Oregon estuarine invertebrates - an illustrated guide to the common and important invertebrate animals: U.S. Fish and Wildlife Service FWS/OBS 83/16, 225 p., accessed January 30, 2015, at http://www.oregon.gov/dsl/SSNERR/docs/ oregonestuarine_invertebrates.pdf.

Satake, K., Shimazaki, K., Tsuji, Y., and Ueda, K., 1996, Time and size of a giant earthquake in Cascadia inferred from Japanese tsunami records of January 1700: Nature, v. 379, no. 6562 , p. 246-249.

Satake, K., Wang, K., and Atwater, B.F., 2003, Fault slip and seismic moment of the 1700 Cascadia earthquake inferred from Japanese tsunami descriptions: Journal of Geophysical Research, v. 108, no. B11, p. 17, doi:10.1029/2003JB002521.

Sawai, Y., Satake, K., Kamataki, T., Nasu, H., Shishikura, M., Atwater, B.F., Horton, B.P., Kelsey, H.M., Nagumo, T., and Yamaguchi, M., 2004, Transient uplift after a 17thcentury earthquake along the Kuril subduction zone: Science, v. 306, no. 5703, p. 1918-1920, doi:10.1126/ science. 1104895 .

Scheidegger, K.F., and Phipps, J.B., 1976, Dispersal patterns of sands in Grays Harbor Estuary, Washington: Journal of Sedimentary Petrology, v. 46, no. 1, p. 163-166, doi:10.1306/212F6EE2-2B24-11D7-8648000102C1865D.

Schile, L.M., Callaway, J.C., Morris, J.T., Stralberg, D., Parker, V.T., and Kelly, M., 2014, Modeling tidal marsh distribution with sea-level rise - evaluating the role of vegetation, sediment, and upland habitat in marsh resiliency: PLoS ONE, v. 9, no. 2, doi:10.1371/journal. pone. 0088760 .

Shennan, I., Long, A.J., Rutherford, M.M., Green, F.M., Innes, J.B., Lloyd, J.M., Zong, Y., and Walker, K.J., 1996, Tidal marsh stratigraphy, sea-level change and large earthquakes - I, a 5000-year record in Washington, U.S.A: Quaternary Science Reviews, v. 15, no. 10, p. 1023-1059, doi:10.1016/S0277-3791(96)00007-8.

Shennan, I., Long, A.J., Rutherford, M.M., Innes, J.B., Green, F.M., and Walker, K.J., 1998, Tidal marsh stratigraphy, sea-level change, and larger earthquakes-II, submergence events during the last 3500 years at Netarts Bay, Oregon, USA: Quaternary Science Reviews, v. 17, no. 4-5, p. 365-393, doi:10.1016/S0277-3791(97)00055-3. 
Shugar, D.H., Walker, I.J., Lian, O.B., Eamer, J.B.R., Neudorf, C., McLaren, D., and Fedje, D., 2014, Post-glacial sealevel change along the Pacific coast of North America: Quaternary Science Reviews, v. 97, p. 170-192, doi:http://dx.doi.org/10.1016/j.quascirev.2014.05.022.

Smith, D.E., Harrison, S., Firth, C.R., and Jordan, J.T., 2011, The early Holocene sea level rise: Quaternary Science Reviews, v. 30, no. 15-16, p. 1846-1860, doi:10.1016/j. quascirev.2011.04.019.

Strasser, M., Monecke, K., Schnellmann, M., and Anselmetti, F.S., 2013, Lake sediments as natural seismographs-a compiled record of Late Quaternary earthquakes in Central Switzerland and its implication for Alpine deformation: Sedimentology, v. 60, no. 1, p. 319-341, doi:10.1111/sed.12003.

Takekawa, J.Y., Thorne, K.M., Buffington, K.J., Spragens, K.A., Swanson, K.M., Drexler, J.Z., Schoellhamer, D.H., Overton, C.T., and Casazza, M.L., 2013, Final report for sea-level rise response modeling for San Francisco Bay estuary tidal marshes: U.S. Geological Survey OpenFile Report 2013-1081, 161 p., http://pubs.usgs.gov/ of $/ 2013 / 1081 /$.

Thatcher, W., 1984, The earthquake deformation cycle at the Nankai Trough, southwest Japan: Journal of Geophysical Research: Solid Earth, v. 89, no. B5, p. 3087-3101, doi:10.1029/JB089iB05p03087.

Thom, R.M., 1984, Composition, habitats, seasonal-changes and productivity of macroalgae in Grays-Harbor estuary, Washington: Estuaries, v. 7, no. 1, p. 51-60, doi:10.2307/1351956.

Törnqvist, T., Bick, S., Gonzalez, J., van der Borg, K., and de Jong, A., 2004, Tracking the sea-level signature of the 8.2 ka cooling event - new constraints from the Mississippi Delta: Geophysical Research Letters, v. 31, no. 23, p. L23309, doi:10.1029/2004GL021429.

Twichell, D.C., and Cross, V.A., 2001, Holocene evolution of the southern Washington and northern Oregon shelf and coast—geologic discussion and GIS data release: U.S. Geological Survey Open-File Report 01-076, http://pubs. usgs.gov/of/of01-076/.

U.S. Coast and Geodetic Survey, 1928, Grays Harbor, Nautical Chart 6195, scale 1:40,000, http://historicalcharts.noaa. gov/historicals/preview/image/6195-5-1928.

Venkatarathnam, K., and McManus, D.A., 1973, Origin and distribution of sands and gravels on northern continentalshelf off Washington: Journal of Sedimentary Petrology, v. 43 , no. 3, p. $799-811$.
Wang, P.-L., Engelhart, S.E., Wang, K., Hawkes, A.D., Horton, B.P., Nelson, A.R., and Witter, R.C., 2013, Heterogeneous rupture in the great Cascadia earthquake of 1700 inferred from coastal subsidence estimates: Journal of Geophysical Research, Solid Earth, v. 118, no. 5, p. 2460-2473, doi:10.1002/jgrb.50101.

Watson, E.B., 2004, Changing elevation, accretion, and tidal marsh plant assemblages in a south San Francisco Bay tidal marsh: Estuaries, v. 27, no. 4, p. 684-698, doi:10.1007/BF02907653.

Wegmann, K.W., Bohnenstiehl, D.R., Bowman, J.D., Homburg, J.A., Windingstad, J.D., and Beery, D., 2012, Assessing coastal landscape change for archaeological purposes - integrating shallow geophysics, historical archives and geomorphology at Port Angeles, Washington, USA: Archaeological Prospection, v. 19, no. 4, p. 229-252, doi:10.1002/arp.1431.

Weinmann, F., Boulé, M., Brunner, K., Malek, J., and Yoshino, V., 1984, Wetland plants of the Pacific Northwest: Seattle, U.S. Army Corps of Engineers, Seattle District, 85 p.

West, D.O., and McCrumb, D.R., 1988, Coastline uplift in Oregon and Washington and the nature of Cascadia subduction-zone tectonics: Geology, v. 16, no. 2, p. 169-172, doi:10.1130/0091-7613(1988)016<0169:CU IOAW $>2.3 . \mathrm{CO} ; 2$.

Whitehouse, P.L., Bentley, M.J., and Le Brocq, A.M., 2012, A deglacial model for Antarctica: geological constraints and glaciological modelling as a basis for a new model of Antarctic glacial isostatic adjustment: Quaternary Science Reviews, v. 32, p. 1-24, doi:10.1016/j. quascirev.2011.11.016.

Willis, J.K., and Church, J.A., 2012, Regional sea-level projection: Science, v. 336, no. 6081, p. 550-551, doi:10.1126/science. 1220366 .

Wolf, S.C., Nelson, H., Hamer, M.R., Dunhill, G., and Phillips, L.R., 1999, The Washington and Oregon mid-shelf silt deposit and its relation to the late Holocene Columbia River sediment budget: U.S. Geological Survey Open-File Report 99-173, http://pubs.usgs.gov/of/1999/0173/.

Yuill, B., Lavoie, D., and Reed, D.J., 2009, Understanding subsidence processes in coastal Louisiana: Journal of Coastal Research, Special issue 54, p. 23-36, doi:10.2112/ SI54-012.1.

Zdanowicz, C.M., Zielinski, G.A., and Germani, M.S., 1999, Mount Mazama eruption-calendrical age verified and atmospheric impact assessed: Geology, v. 27, no. 7, p. 621-624, doi:10.1130/0091-7613(1999)027< 0621:MMECAV>2.3.CO;2. 
Menlo Park Publishing Service Center, California Manuscript approved for publication on April 23, 2015 Edited by Peter H. Stauffer and Katherine D. Jacques Design and layout by Jeanne S. DiLeo 


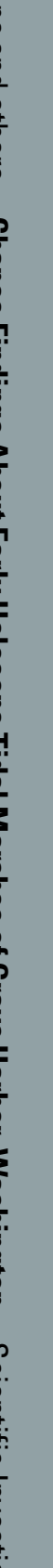

